\author{
Universidade de São Paulo \\ Faculdade de Filosofia, Letras e Ciências Humanas \\ Departamento de Filosofia \\ Programa de Pós-Graduação em Filosofia
}

Andre Scoralick

\title{
Experiência e Moralidade \\ no último dos Ensaios de Montaigne
}

São Paulo

2008 
Andre Scoralick

\section{Experiência e Moralidade \\ no último dos Ensaios de Montaigne}

Dissertação apresentada ao Programa de PósGraduação em Filosofia, do Departamento de Filosofia da Faculdade de Filosofia, Letras e Ciências Humanas da Universidade de São Paulo, para obtenção do título de Mestre em Filosofia, sob a orientação do Prof. Dr. Sérgio Cardoso

São Paulo

2008 


\section{AGRADECIMENTOS}

À Glaucia, meu amor, pelo imenso apoio e profundo carinho, sem os quais este trabalho não teria sido realizado.

Ao José Emílio, à Nicia e à Gleyci, pela recepção carinhosa durante toda a escrita da dissertação.

Aos meus pais, a quem tudo devo: o que sou e o que posso.

À Paty, pela paciência e compreensão.

À Capes, pelo apoio e financiamento.

À Marie, Maria Helena, Roseli, Luciana, Geni e Verônica, da Secretaria do Departamento de Filosofia, pelo auxílio e atenção.

Ao Prof. Dr. Franklin Leopoldo e Silva e à Profa. Dra. Marilena de Souza Chauí, pelas valiosas contribuições que suas argüições, em minha qualificação, trouxeram para este estudo.

Aos colegas e professores participantes do Grupo de Estudos Renascentistas (Eduíno, Sandra, Patricia, Rita, Lúcio, Fabrina, Sérgio, Prof. Alberto Barros, Profa. Maria das Graças de Sousa), pelos debates sempre enriquecedores.

Ao Edson Querubini, pela leitura atenta de todo o estudo, pelas sugestões e correções que deram alguma consistência a este trabalho.

E, muito especialmente, ao Prof. Dr. Sérgio Cardoso, pela orientação meticulosa, profunda atenção e generosidade incomensurável. 


\section{RESUMO}

SCORALICK, A. Experiência e Moralidade no último dos Ensaios de Montaigne. 2008. 141 f. Dissertação (Mestrado) - Faculdade de Filosofia, Letras e Ciências Humanas. Departamento de Filosofia, Universidade de São Paulo, São Paulo, 2008

O presente estudo visa constituir uma introdução à reflexão ética que Michel de Montaigne desenvolve em seus Ensaios. Trata-se, de maneira mais específica, de uma análise do capítulo Da experiência, ensaio com que o autor encerra sua obra e apresenta, sob a forma de um testamento, os pontos essenciais de sua orientação moral. Procuramos compreender os fundamentos de sua recusa de toda ética normativa e a correlata elaboração de uma moral afeita à singularidade dos agentes e às circunstâncias das ações. Para tanto, buscamos reconstituir a crítica do ensaísta às artes que pretendem regular as condutas humanas - a jurisprudência e a medicina - e à moral estóica, assim como elucidar a experiência de si, de que Montaigne deriva uma ética em que o prazer se concilia com a virtude e o agente consigo mesmo.

\section{PALAVRAS-CHAVE}

Montaigne; ética; experiência; experiência de si; artes de viver; 


\begin{abstract}
SCORALICK, A. Experience and morality in Montaigne's last essay. Faculdade de Filosofia, Letras e Ciências Humanas, Departamento de Filosofia, Universidade de São Paulo, 2008. Thesis.

The present study aims at introducing Michel de Montaigne's ethical reflexion, as exposed in his Essays. It is, more specifically, an analysis of the chapter On experience, the essay with wich the author finishes his work, and presents, as in a will, the essential topics of his moral orientation. We seek to understand the fundaments of his refusal of all normative ethics, and the project of elaborating a moral fit to the singularity of agents and the circumstances of action. To do so, we undertake the reconstruction of the author's criticism to the arts that intend to regulate human conducts - jurisprudence and medicine -, and to the Stoic moral. We also try to clarify the experience of oneself, from which Montaigne derives a moral that reconciles pleasure and virtue, and the agent with himself.
\end{abstract}

\title{
KEYWORDS
}

Montaigne; Ethics; experience; experience of oneself; arts of living 


\section{Sumário}

Introdução

Capítulo 1: A Orientação Moral pela Arte

1. O Trabalho da Diferença

2. A Crítica da Glosa e da Interpretação

3. A Imperfeição das Leis Humanas e a Inapreensibilidade das Leis

Naturais

Capítulo 2: A Orientação Moral pela Experiência

1. As Artes de Viver e a Experiência de Si

2. A Medicina e a Natureza do Corpo

68

3. A Reconciliação com o Prazer

92

Conclusão

Anexos

Anexo I - A Querela das Artes

Anexo II - Platão e o paradigma da Arte 


\section{Introdução}

O presente estudo tem como objeto questões cujo exame nos permite compreender de maneira mais ampla o pensamento de Montaigne acerca da ética - e, de maneira geral, acerca das condições de regulação das condutas -, pensamento este que se desenvolve a partir do recurso à experiência de si, constitutiva do sujeito, e à observação empírica das circunstâncias em que se encontram mergulhados os agentes morais. Trata-se, em última instância, de uma etapa na busca de uma compreensão sólida da própria empresa dos Ensaios, que, sintetizando a "apreensão de si" e a "observação do mundo", permitem abordar a ação moral na sua complexidade própria, além de enfatizarem as condições culturais, sociais, e históricas do comportamento ético ${ }^{1}$.

Um dos acessos mais consistentes às reflexões éticas montaigneanas encontra-se no ensaio III 13, Da experiência, considerado pela tradição crítica como ponto alto e crucial neste domínio². Isto porque, neste texto, Montaigne não apenas apresenta seus próprios "parâmetros" para a conduta moral, mas, sobretudo, reflete sobre as condições de sua formulação e sobre o estatuto do

\footnotetext{
${ }^{1}$ Sobre o caráter cultural, social e histórico da ética para Montaigne, cf. CARDOSO, Sérgio. "Uma fé, um rei, uma lei - A crise da razão política na França das guerras de religião", in NOVAES, Adauto (Org.). A Crise da Razão. São Paulo: FUNARTE, Cia das Letras, 1996, p. 184-193.

${ }^{2}$ Cf., por exemplo, Tournon, A. Montaigne, Paris: Bordas, p. 107-108: "dans la version achevée en 1588, le dernier chapitre en assure la cohérence [assegura a coerência da entreprise montaigneana] en liant plus étroitement que jamais la critique de la connaissance et le projet d'émancipation. II traite 'De l'expérience' [...]"
} 
saber adequado à compreensão e orientação de nossas práticas. Espécie de testamento do autor, porquanto encerra sua obra e lhe confere seu tom final, Da experiência revela-se, assim, o terreno mais fértil para a investigação das concepções éticas de Montaigne não apenas porque, como diz Villey, "quant à la morale, nulle part il n'a exprimé avec plus de fermeté et de bonheur que dans les dernières pages de cet essai l'ensemble des idées par lesquelles se formule sa conception de la sagesse" ${ }^{3}$, mas principalmente porque, como veremos, depois de uma decisiva reflexão crítica de perfil epistemológico, o autor estabelece aí o alicerce sobre o qual repousam suas concepções éticas: a experiência - que é, antes de tudo, experiência de si.

Da experiência se nos apresenta, pois, como uma longa meditação sobre a questão da "boa condução da vida", realizada a partir da indagação de Montaigne sobre seu próprio modo de agir, de sua análise de ações e costumes alheios, e de sua experiência dos males que afligem a vida humana a doença, a velhice e a iminência da morte. Esta "dissertação moral" - que encena um saber prático vivo, cioso da condição corporal e afetiva dos homens - ocupa, sobretudo, os três últimos quartos do texto, sendo precedida "logicamente" por uma reflexão de perfil epistemológico, que constitui o movimento propriamente crítico do ensaio, conduzido principalmente ao longo dos trinta primeiros parágrafos ${ }^{4}$. É já no seu mesmo início que vemos

\footnotetext{
${ }^{3}$ Cf. nota de apresentação do ensaio, Montaigne, M. Les Essais. Édition de Pierre Villey, reéditée par V. L. Saulnier. Paris: PUF, 1999, p. 1064. (Col. Quadrige). Todas as referências aos Ensaios, bem como todas as citações, nesta dissertação, são feitas a partir desta edição.

${ }^{4}$ No entanto, como é próprio do ensaio, que via de regra não admite cortes muito precisos em suas articulações, vemos mescladas estas duas "faces" do texto - a crítica e a ética - ao longo de seus desenvolvimentos. Montaigne move uma longa e acerba crítica à pretensão de
} 
despontar esta empreitada crítica pela consideração da pretensão normativa da jurisprudência, pela indicação de seus equívocos e violência, e pela denúncia da fragilidade de seus fundamentos epistêmicos. Montaigne censura a pretensão desta disciplina ao status de "ciência prática" do direito e, sobretudo, o intento de constituí-la como "arte" (tékhne, saber verdadeiro de nexos universais - no interior de um gênero - entre causas e efeitos ${ }^{5}$ ), o grande projeto do humanismo jurídico de seu tempo ${ }^{6}$. Esta crítica de ordem epistemológica não se limita, no entanto, à arte jurídica, mas volta-se ainda contra a arte da medicina que, assim como a jurisprudência, pretende estabelecer normas gerais - esta para os cuidados do corpo - e que também reivindica para si o status de saber verdadeiro de nexos causais no domínio das afecções e dos padecimentos do corpo.

controle "técnico" das condutas que vai, por assim dizer, desenhando aos poucos toda uma paisagem a explorar, devolvendo-nos à experiência como seu solo, mais claramente visível nas partes finais do capítulo.

${ }^{5}$ Não estranhe o leitor o vocabulário explicitamente aristotélico assumido aqui, na medida em que a problemática tanto montaigneana quanto da "Querela das Artes", que abaixo mencionaremos, têm, a nosso ver, o pensamento de Aristóteles como pano de fundo. Sobre o fato de Aristóteles estar no horizonte das reflexões montaigneanas, observe-se que o ensaio Da experiência é iniciado com uma explícita menção ao filósofo grego (Cf. Essais III 13, p. 1065).

${ }^{6}$ Referimo-nos ao frustrado projeto, originalmente de Cícero (que, no De Oratore, I, XLII, havia reivindicado a exposição do Direito Romano numa ordem simples, clara e racional, contra a apresentação desconexa e confusa de um amontoado de casos particulares), de sistematização do Direito Romano - "jus in artem redigere" -, concebido pelos juristas humanistas do Mos Gallicus, esteado na crença da inteira racionalidade dos elementos deste Direito. 
Tais considerações levam nosso autor a compreender o campo da ética e das condutas em geral num sentido totalmente diverso daquele das "artes de viver": as condutas individuais não devem se regular por um saber pretensamente universal ou pelas prescrições de uma arte, mas, como veremos, pelo trabalho da experiência de si, pelo conhecimento de si na sua irredutível singularidade.

É, pois, esta crítica das "artes" supracitadas que constitui a base de sua reflexão sobre a condução da vida e sobre o estatuto do "saber" que a torna possível. É, em suma, após desqualificar o procedimento de elaboração de normas e leis a partir da experiência (e de recusar, por conseqüência, a possibilidade de se constituir um conhecimento certo e universal acerca das condutas humanas, assim como a legitimidade das normas que daí se derivam), que Montaigne recupera a observação empírica como "meio" para constituir um "saber" peculiar sobre as condutas, introduzindo a noção de experiência - e, mais do que isso, de experiência de si - como elemento central de seu projeto. A observação e inspeção de si revelam-se, então, as fontes primordiais do saber prático montaigneano. Este saber, que opera com noções gerais apenas à medida que são destituídas do peso essencialista que lhes dão as artes ou ciências, não entende mais expressar uma abstrata universalidade, mas busca, ao contrário, apreender os casos na sua singularidade, na sua irredutibilidade a qualquer forma genérica de identidade.

Estas breves indicações sobre o ensaio Da experiência, permitem-nos perceber a importância capital do eixo crítico-epistemológico que atravessa boa parte do texto, enquanto recusa de certo modelo de compreensão do campo das práticas humanas e de busca, para ele, de uma forma possível de saber. 
Nesse sentido, o exame da crítica da medicina e da jurisprudência revela-se condição essencial do esclarecimento da alternativa prática apresentada por Montaigne - o qual, por sua vez, ilumina e amplia a compreensão de vários outros elementos do seu pensamento ético. Por outro lado, nós acreditamos - e este foi o ponto de partida de nossa investigação - que o teor da crítica dirigida pelo autor a tais artes só se esclarece adequadamente quando examinamos seu contexto intelectual e cultural - sua inscrição muito particular na chamada Querela das Artes renascentista ${ }^{7}$-, bem como seus enraizamentos conceituais na tradição mais remota da filosofia grega ${ }^{8}$. Deste modo, acreditamos que se

\footnotetext{
${ }^{7}$ Famosa polêmica erudita que, no séc. XV, opôs intelectuais, médicos e juristas, numa discussão relativa à maior dignidade das leis ou da medicina. Carlo Colombero, no texto Uomo e natura nella filosofia Del Rinascimento (Loescher, 1976), apresenta, como envolvidos nesta querela: Francesco Petrarca, Coluccio Salutati, Poggio Bracciolini, Nicoletto Vernia, Antonio
} De'Ferrariis, Matteo Palmieri, Bartolomeo Sacchi e Benedetto Varchi. Eugenio Garin, por sua vez, na coletânea La Disputa Delle Arti nel Quattrocento (Firenze, Vallecchi, 1947), apresenta também textos de Giovanni Baldi, Leonardo Bruni, Giovanni D’Arezzo e Bernardo llicino. Procuramos desenvolver as linhas gerais deste debate, não no corpo de nossa dissertação, mas em anexo, de modo a fornecer elementos aos nossos leitores para julgar da pertinência de nossa leitura de Da experiência. Cf. Anexo I: "A Querela das Artes".

${ }^{8}$ Não ignoramos a ambiência mais segura e insistentemente repisada pelo comentário dos Ensaios na filosofia grega helenística, representada pelas escolas estóica, epicurista e cética. Uma certa inscrição no pirronismo, por meio da apropriação dos expedientes argumentativos dos céticos, depois de um século de comentário, é quase incontestável. No entanto, como primeiro passo de um percurso que está ainda longe de se encerrar nesta dissertação, julgamos importante e defensável a escolha do confronto das posições de Montaigne neste último capítulo dos seus Ensaios com o pensamento de Platão e de Aristóteles. Dois motivos, ao menos, poderiam ser alegados, para além dos elementos que tentaremos explicitar em nosso percurso: a querela que estudamos de início se insere num ambiente fortemente 
esclarecem de maneira mais significativa muitos de seus posicionamentos em relação à questão destacada acima.

Ao longo de nossa análise, ser-nos-á possível verificar que, recusando a ambas as artes, que pelejavam há pouco pela palma, a dignidade que almejavam, Montaigne ultrapassa a ótica limitada dos querelantes, evidencia a estreiteza da perspectiva que tomam e assinala a batalha que realmente importa travar. Médicos e juristas disputam entre si e defendem cada um a sua arte, a partir, uns e outros, do mesmo horizonte humanista da celebração da dignitas hominis e da capacidade desta criatura divina de não apenas conhecer o mundo, mas de transformá-lo ou mesmo recriá-lo e elevá-lo, pela intervenção das artes humanas, pelas criações de seu espírito. Montaigne, por seu lado, já não pretende desqualificar a medicina em nome da jurisprudência, ou esta em nome daquela. Para o autor dos Ensaios, trata-se, antes, de recusar as ambições demiúrgicas das técnicas e sua pretensão de humanizar a natureza, legislar sobre as cidades e orientar as ações dos homens no cuidado de si mesmo e do mundo.

Como apontado, no entanto, a censura montaigneana à ambição das técnicas parece encontrar referências mais remotas que este projeto cultural que alcança seu século. A inspeção de sua crítica nos permitirá observar que as reflexões propostas no $\mathrm{Da}$ experiência ecoam, ainda que de maneira indireta, o debate sobre o estatuto do saber prático e a natureza da ética, inaugurado por Platão e Aristóteles - numa problemática, portanto, que

escolástico, por um lado; Montaigne, por outro, intensifica suas leituras de Platão no fim da vida e nas fases finais de escrita do seu livro, e pinta com cores mais nítidas seu "socratismo" que, a nosso ver, contrasta com o do jovem Platão. 
constitui um dos núcleos da história da filosofia.

Certas referências prováveis ao diálogo Górgias no ensaio $D a$ experiência, por exemplo, mostram que Montaigne tinha alguma ciência do caráter de modelo de conhecimento e paradigma ético-político que as artes possuíam para o jovem Platão ${ }^{9}$. Ressaltando a fragilidade dos alicerces da arte, e apontando a violência que há na aplicação de suas normas - formais em sua estrutura - à particularidade insuperável das matérias em causa na esfera moral, Montaigne parece tomar como alvo a figura do jovem Platão e sua herança da "ética intelectualista socrática". O ataque montaigneano a Platão se torna ainda mais evidente quando consideramos as artes escolhidas como alvo pelo ensaísta: medicina e justiça, as tekhnai mais honradas e respeitadas pelo filósofo do Górgias, únicas atividades capazes de restaurar a saúde do corpo e da alma dos homens, conduzindo-os à felicidade.

Para o jovem Platão, a conduta moral virtuosa - assim como a boa atividade política - refere-se a um saber de natureza técnica. Assim como o artesão produz com sucesso suas obras porque conhece a idéia do objeto que deve produzir - isto é, sua finalidade e função - e, portanto, as regras que desta se derivam, o virtuoso, do mesmo modo, age de maneira excelente

\footnotetext{
${ }^{9}$ Cf. Anexo II: "Platão e o paradigma da Arte". A este respeito, cf. Giuseppe Cambiano, Platone e le tecniche, p. 83: "Nos primeiros diálogos platônicos, as técnicas aparecem como o modelo epistemológico por excelência. As técnicas são a exemplificação do que significa 'saber'." Cf. também Henri Joly, Le renversement platonicien, p. 230: "Desde os primeiros diálogos, com efeito, a questão da política se encontra abordada em termos de ciência e de técnica, e recebe de um confronto com as estruturas simples da racionalidade artesanal e de uma comparação com os ofícios freqüentemente os mais humildes sua primeira clareza metafórica e o sentido de suas primeiras exigências."
} 
porque conhece a idéia do bem, extraindo desta as regras para sua ação. Esta concepção intelectualista da ética - segundo a qual a excelência moral consiste única e exclusivamente no conhecimento do bem - é inteiramente afastada, como veremos, por Montaigne em Da experiência. Como argumento contra a violência da aplicação de prescrições médicas a homens de idade avançada e de hábitos opostos aos que Ihes são prescritos, Montaigne considera que a compleição moral e física de cada um é fruto dos hábitos que cada qual longamente cultivou, de modo que as condutas que habitualmente seguem somente podem Ihes fazer bem. Mostra, assim, que a boa orientação relativa ao corpo ou às ações não vem de um conhecimento racional que estabeleceria o que é reto para aquele gênero de caso, mas do hábito, que nos move cada vez com mais força à medida que reitera cada vez mais nosso desejo.

Assim, quando recusa a violência da pretensão normativa das técnicas sobre as condutas humanas, Montaigne ao mesmo tempo assinala a fronteira que separa a técnica da ética: se a ação técnica depende única e exclusivamente do conhecimento das regras de ação (de tal modo que a capacidade do artista pode ser transmitida por um ensino de natureza exclusivamente intelectual) a ação moral, por seu lado, depende de uma disposição desiderativa, forjada pelo hábito. Por esta clara separação das esferas técnica e moral, podemos, então, observar que Montaigne, contra Platão, aproxima-se da perspectiva aristotélica. Pois, foi Aristóteles, de fato, quem atacou de maneira mais incisiva a ética intelectualista socrática, sustentando no último capítulo do livro VI da Ética Nicomaquéia que a virtude moral é uma excelência não apenas intelectual, mas também desiderativa, não bastando que o agente conheça o bem por meio da deliberação para que aja 
bem, mas sendo necessário, além disso, que ele deseje agir de tal modo (isto é, que, pelo hábito, refira seus apetites e encontre seu prazer no fim adequado).

A resposta de Aristóteles a Sócrates sobre o fenômeno moral da "incontinência", nesse sentido, é emblemática. Pois, concebendo a virtude moral como uma disposição desiderativa, o estagirita entende explicar a atitude do homem que sabe o que deve fazer, mas escolhe (porque deseja) o que não deve fazer, arrependendo-se quando o desejo, satisfeito, não mais se manifesta. Nesta perspectiva, em que o hábito de agir corretamente é um dos pilares em que repousa a excelência moral (sendo o outro o cálculo que determina o que se deve fazer), a educação assume um posto preponderante, pois, para que se tornem virtuosos, os jovens passam a ter de ser habituados a agir corretamente (ou, antes, a desejar agir corretamente) sob a orientação do homem prudente, que sabe o que é correto fazer, conhecendo o fim que se deve desejar (a virtude, meio para a felicidade) e os meios capazes de levar a ele (a ação de acordo com a justa medida). Para Aristóteles, a reta razão do prudente é o critério que determina a virtude moral - a mediania -, que deve ser buscada pelos jovens desde a mais tenra infância, num exercício cotidiano que, aos poucos, neles forja uma disposição moral virtuosa. Neste processo, quanto mais o tempo passa mais a prática de buscar o fim correto e escolher os meios que levam a ele torna-se um hábito 'espontâneo', a ponto de se consolidar como caráter excelente, na vida adulta.

É Aristóteles, portanto, quem ensina a Montaigne o papel do hábito e da dimensão desiderativa na formação da compleição moral dos indivíduos, e que a força do tempo dificulta em larga medida a mudança de conduta por parte do 
homem maduro (EN III 7, 114a3-23). No entanto, é justamente quando critica a aplicação de prescrições médicas a homens de idade avançada e de hábitos contrários ao que lhes é prescrito, que o autor dos Ensaios nos mostra sua distância em relação ao aristotelismo. O limite desta aproximação está, certamente, na recusa montaigneana em admitir o uso de normas ou paradigmas morais exteriores à própria constituição do sujeito - à exceção daquelas que lhe impõem condutas no registro público, diante das quais, como veremos, o exercício da liberdade deve se dar em outros termos.

A tolerância montaigneana para com os hábitos do velho deve, nesse sentido, ser cuidadosamente interrogada, já que suas razões exprimem o ponto de ruptura que afasta o autor dos Ensaios da perspectiva aristotélica. Para Aristóteles, o velho vicioso ainda tem o dever de se esforçar para seguir as prescrições do prudente. Se sua compleição moral adere a seus hábitos, tornando difícil a mudança de seu comportamento na direção do que determina o phrónimos, isto não torna as normas que este the oferece expressão de violência. Ao contrário, elas são legítimas e justificáveis, na medida em que exprimem a verdade prática e dirigem o velho vicioso pelo único caminho possível para sua felicidade - sendo antes, portanto, expressão de amizade. Para Montaigne, no entanto, a singularidade irredutível das ações e dos agentes torna impossível a formulação de um conhecimento necessariamente geral - a seu respeito, assim como de normas capazes de orientá-los com alguma segurança. Toda pretensa verdade prática, na realidade, não escapa ao registro das opiniões e, uma vez imposta ao agente, é mera expressão de arbitrariedade e violência. Montaigne é tolerante para com o homem maduro que sofre diante da medicina porque não há, na esfera 
privada, normas ou paradigmas práticos legítimos. Ao prescrever para ele que siga seus hábitos, o autor, na verdade, aconselha-o a não se violentar em nome de uma medida ou de uma regra que não tem um alcance geral, que não pode ser erigida em universal prático.

Mas, a tolerância montaigneana para com os homens de idade tem ainda outras razões. O autor dos Ensaios reconhece, na figura do homem de hábitos cristalizados, o sofrimento de quem não consegue se adaptar às vicissitudes da vida, a dor de quem não consegue se adequar à mudança das circunstâncias e de si mesmo, e que, na sua fixidez, é atingido pela variação dos tempos. Neste terreno, a experiência que o ensaísta faz de sua própria doença é emblemática. E não apenas porque aproxima ainda mais o velho Montaigne da morte, colocando-o face a face com ela e obrigando-o a refletir sobre ela, mas ainda porque revela, em primeira pessoa, o embate de quem se vê pressionado pela arte dos médicos a abandonar hábitos há tanto tempo cultivados para se livrar de um mal inesperado. Tais temas - variação das circunstâncias da ação e da Fortuna -, vastamente explorados por Aristóteles na Ética Nicomaquéia, são assimilados por Montaigne e postos sob a luz de uma perspectiva nova: se não há balizas práticas universais, se as circunstâncias da ação sempre se alteram, e se a fortuna sempre pode girar sua roda de maneira inesperada, é necessário habituar-se à mudança e à variação, como forma de constituir para si mesmo uma disposição flexível que permita acolher as vicissitudes da vida. Trata-se, portanto, de enfrentar as diferenças dos tempos, relativizando a sujeição aos hábitos - os bons hábitos que, em Aristóteles, forjam a autonomia do homem virtuoso (habituado a desejar o fim correto e a escolher deliberadamente os meios que o levem a 
ele), mas que, para Montaigne, ainda eles, escravizam o homem maduro, impedindo-o de responder à variação das circunstâncias e de si mesmo.

Uma possível filiação do ensaísta à ética aristotélica - que se esboça na assimilação montaigneana de concepções como a constituição do caráter pelo hábito, a disposição desiderativa, o estatuto circunstancial das ações e o tema trágico da variação da fortuna - rompe-se, portanto, ao colocar-se em questão seu aspecto normativo. A desqualificação do teor de verdade das prescrições técnicas e morais é feita por quem sabe que a singularidade das ações e dos agentes termina por falsear toda norma ou paradigma prático, necessariamente exteriores à "condição" do agente moral - seja referentes às condutas corporais, seja às afecções internas do sujeito. Para Aristóteles, é indiscutível que o médico é competente para prescrever a melhor dieta ou o tratamento mais adequado para determinada doença, porque ele conhece os meios capazes de produzir a cura - ainda que este conhecimento não goze do mesmo grau de certeza e exatidão que o das ciências teoréticas. É indubitável, para ele, que o phrónimos pode prescrever em cada caso o melhor modo de agir para se chegar à felicidade, à medida que é capaz de deliberar corretamente sobre os meios de atingir o supremo bem, chegando à verdade referente às matérias da práxis por meio do silogismo prático. Do ponto de vista montaigneano, contudo, não há verdade a ser prescrita relativamente aos modos de agir ou de cuidar do próprio corpo - de modo que o médico e o prudente são definitivamente afastados de seu papel de portadores de normas práticas universalmente válidas.

Segundo Montaigne, somente a experiência é capaz de oferecer balizas para a orientação das condutas. Mas, "que gênero de experiência é esta?" - 
devemos nos perguntar - visto que o ensaísta desqualifica as técnicas justamente afirmando que a experiência sobre a qual elas repousam não produz conhecimento. Seria uma experiência semelhante à do prudente aristotélico? Sabemos, pelo oitavo capítulo do livro VI da EN, que o phrónimos é também o homem experiente, familiarizado com o particular, pois, do contrário, não poderia chegar à premissa maior do silogismo prático, nem formular sua premissa menor. Verificaremos, no entanto, que, em Montaigne, a experiência não funda nenhum cálculo prudencial. O experiente montaigneano é o homem que possui, como o phrónimos, familiaridade com o particular, mas sua experiência é, antes, aquela relativa à singularidade inarredável de todas as coisas; não vence a dessemelhança e não permite a realização do processo indutivo na direção de uma universalidade. Esta experiência, que opera no domínio da infinita diversidade dos casos e situações, no mundo da contingência, da mudança e da variação, exige que a ação seja sempre renovada e impede a constituição de qualquer critério fixo para sua orientação. É esta mesma experiência que leva Montaigne a prescrever aos jovens a adoção de uma conduta flexível e o exercício da variação, de modo a tornaremse aptos a se adequar às novas situações e circunstâncias de sua ação e a suportar com vigor e tranqüilidade as variações da Fortuna.

Procuraremos, portanto, nas páginas que se seguem, realizar o exame o mais atento e circunstanciado possível - do trajeto de interrogação e pensamento que nos é proposto por Montaigne neste belíssimo ensaio que ele denominou, justamente, Da experiência. Na primeira parte de nosso estudo, daremos atenção, sobretudo, ao viés crítico do texto que destacamos mais acima. Procuraremos, em primeiro lugar, explicitar os pressupostos a partir dos 
quais a jurisprudência e a medicina tradicionalmente se constituíam como disciplinas técnicas para, em seguida, avaliar a desmontagem operada por nosso autor de sua pretensão reguladora. Em sua segunda parte, nos deteremos na noção de experiência que a crítica permitiu isolar e circunscrever, bem como na exploração da ética que o ensaísta destaca e expõe, já que a leitura deste texto, talvez mais do que a de qualquer outro dos Ensaios, leva-nos a uma compreensão mais nítida da originalidade do empreendimento ético montaigneano, além de nos proporcionar, através da própria experiência do autor (já, então, no fim de sua vida), um extraordinário relato dos princípios "que o levaram tão longe" - princípios não professados, mas profundamente vividos e meditados, ou, mais propriamente, profundamente vividos, porque meditados. 


\section{Capítulo 1 - A Orientação Moral pela Arte}

"Composer nos meurs est nostre office [...]. Nostre grand et glorieux chef-d'oeuvre c'est vivre à propos." (Essais III 13, p. 1108). Estas duas frases, colhidas quase ao fim do Da experiência, exprimem bem o propósito do capítulo de encerramento dos Ensaios de Montaigne. Em seu conjunto, as considerações do ensaísta nos convidam aos caminhos em que se interroga sobre como "mediter et manier [n]ostre vie", sobre como realizar "la plus grande besoigne de toutes" - tão simplesmente "viver bem", ou seja, em sua bela e modesta formulação: "vivre à propos". E já o título, por um lado, remete explicitamente esta "finalidade" à noção de "experiência" e a abertura da discussão, por outro, a algum "saber" que, derivando desta, concorreria para a realização daquele mesmo fim.

Precisamente, após ter denunciado, na Apologia de Raymond Sebond, a incapacidade da razão de nos conduzir ao conhecimento das coisas - por se tratar de uma mera capacidade discursiva, um instrumento maleável ${ }^{10}$ por meio do qual podemos sustentar teses opostas ${ }^{11}$ com igual força persuasiva, sem que disponhamos de condições para em seguida decidir e escolher -, resta a Montaigne, no último de seus ensaios, examinar o outro meio pelo qual podemos buscar o conhecimento: a experiência. A primeira vista, poderia parecer que se trata apenas da consideração de um outro recurso ("entremise"), em que se apóiam os homens quando a razão falha, e que viria

\footnotetext{
10 "um instrumento de chumbo e de cera, alongeable, ployable e acomodável à tous biais e a todas as medidas". (Essais II, 12, p. 565)

11 Ou mesmo "cem contrárias em torno de um mesmo assunto". (ibid.)
} 
satisfazer este que é para o homem o "desejo mais natural”. Afinal, não é com o eco evidente da abertura mesma do primeiro livro da Metafísica de Aristóteles que se abre este último capítulo do livro? "Il n’est désir plus naturel que le désir de connaissance" (Essais III 13, p. 1065).

No entanto, Montaigne imediatamente assinala que este instrumento geralmente tomado como "plus foible et moins digne" que a razão, mas que, diz, não deve deixar de ser experimentado, ensaiado, dada a eminência do alvo que através dele procuramos: a verdade ${ }^{12}$-, não conduz propriamente a nenhum conhecimento. Em uma breve tira Montaigne, como que trazendo todo resultado de sua Apologia à baila, nos põe em presença do tropo mais fundamental empregado pela tradição cética pirrônica, sustentáculo mesmo de sua posição "suspensiva": a diaphonía e a conseqüente problemática do critério de escolha diante da multiplicidade de formas tomadas pela razão: "la raison a tant de formes, que nous ne savons à laquelle nous prendre" (ibid.). E disto aproxima uma nova multiplicidade, a das formas da experiência, aparentemente tão desestabilizadora das certezas quanto a primeira. Tudo parece indicar-nos que estamos diante da abertura de um novo litígio, que a pretensão de fundar in extremis alguma ciência ou arte, agora apoiando suas certezas não nas especulações da razão, mas nas semelhanças presentes nas próprias coisas que nos são dadas pela experiência - ciência ou arte que nos ajudaria na condução de nossa vida -, fica descartada desde as primeiras linhas do ensaio pelo anúncio de uma nova invectiva ${ }^{13}$. Tudo se passa como se

\footnotetext{
12 “[...] mais la verité est chose si grande, que nous ne devons desdaigner aucune entremise qui nous y conduise." (Idem, ibid., p. 1065)

${ }^{13}$ Anúncio, aliás, confirmado algumas páginas adiante, em que pela própria insistência
} 
houvesse a necessidade de combater e desalojar esta pretensão de saber que, como veremos na análise deste primeiro momento do texto, não deixa de ter conseqüências funestas, no âmbito da moral, da política, da religião e do próprio cultivo dos studia humanitatis. E ser-nos-á preciso avaliar no fim do percurso que encerra o conjunto do livro - e que, por assim dizer, reafirma muitas das "posições" conquistadas ao longo dos Ensaios - o que articulará a noção de "experiência" que o capítulo investiga e ponderar seus ganhos. Seu primeiro passo, porém, parece exibir uma orientação evidentemente crítica.

\section{O trabalho da diferença}

Já o início deste exame nos leva para o centro do problema da "indução"14 , se nos for concedido empregar um rótulo conveniente: a noção de semelhança, a partir da qual se fundariam certezas no âmbito da experiência, pois através dela teríamos acesso a um núcleo de identidade que perpassaria a "diversidade e variedade" dos fenômenos, da "imagem das coisas". Ora, é precipuamente contra a ilusão da presença de um núcleo estável e uno no cerne da realidade, ou ao menos no cerne da imagem impressa passivamente em nós desta realidade (em nossas representações - Montaigne se serve

anafórica do verbo promettre já se entrevê a opinião contrária de nosso autor: "Les arts qui promettent de nous tenir le corps en santé et l'ame en santé, nous promettent beaucoup; mais aussi n'en est il point qui tiennent moins ce qu'elles promettent." (Ibid., p. 1079.)

${ }^{14}$ Montaigne cita Manílio, I, LIX, que recolhe em fórmula lapidar o entendimento herdado pela antiguidade sobre a constituição das artes e indica a experiência como seu fundamento:"Per varios usus artem experientia fecit: Exemplo [isto é, o caso] monstrante viam" (De l'experience, p. 1065). 
freqüentemente da palavra fantaisie ao longo dos Ensaios, e nela reconhecemos o decalque do conceito estóico de "representação": phantasía), que se volta a tese geral sobre aquela natureza vincada de "diferença" que produz sempre a "dessemelhança". O alvo da tese mobilizada neste início da argumentação parece ser uma concepção pressuposta que projeta, sob ou por trás da mudança, diversidade e variação observadas na natureza, um elemento essencial, imutável e estável, a fim de garantir senão a infalibilidade e a verdade de um discurso geral que sobre ela se formule - pois, até reconheceria que a inscrição no mundo da contingência se faz às expensas da necessidade e da determinação -, ao menos um acerto assegurado pela "regularidade" observada entre as coisas e os eventos passados e os possíveis eventos futuros. Ainda que reconheça sempre a possibilidade da interferência da fortuna ou do acaso, e a não vigência de uma necessidade absoluta no seio mesmo das coisas mutáveis, tal concepção tentaria fundar nesta "regularidade", colhida da semelhança, o seu saber.

A experiência, em sua tentativa de produzir a "arte", operaria, de fato, com a semelhança de certo conjunto de ocorrências, extraindo algo comum a partir da memória ${ }^{15}$ das várias instâncias que compõem este conjunto e,

\footnotetext{
${ }^{15}$ Cf. Aristóteles, Metafísica, A, 1, 980b29-981a13 : 'Da recordação nasce, para os homens, a experiência, pois muitas recordações da mesma coisa chegam a constituir uma experiência. (...) Nasce a arte quando, de muitas observações experimentais, surge uma noção universal (kathólou) sobre os casos semelhantes. Pois ter a noção de que a Cálias, afetado por tal doença, fez bem tal remédio, e o mesmo a Sócrates e a muitos outros considerados individualmente (kath'hékaston), é próprio da experiência; mas saber que foi proveitoso a todos os indivíduos de tal constituição, agrupados em uma mesma classe e afetados por tal doença, por exemplo aos fleumáticos, aos biliosos ou aos febris, corresponde à arte". Aristóteles faz,
} 
simultaneamente, desprezando o que cada uma tem de radicalmente particular. E a partir dessa comunidade de essência, desse núcleo de identidade, inventaria as regras universais de operação, fixadas então em doutrina, por meio das quais realizaria tranqüilamente o homem sua inserção quase sempre feliz e bem-sucedida em meio ao fluxo da mudança, na posse de um saber que Ihe facultaria agir e produzir com alguma previsão segura. Segurança tanto mais grave e importante por se tratar do exame - no ensaio que analisamos não de quaisquer técnicas, mas das regras que produziriam, de um lado, a justiça, no corpo político, e de outro, a moderação das condutas e a saúde corporal, no domínio privado.

Mas a advertência montaigneana não tarda. É preciso admitir que "la consequence que nous voulons tirer de la ressemblance des evenemens est mal seure, d'autant qu'ils sont tousjours dissemblables" (ibid.). Montaigne

pois, a arte se assentar na experiência, e caracteriza a primeira pela sua capacidade de reconhecer e atuar sobre uma generalidade, perspectiva que certamente está no horizonte da crítica montaigneana. Mas, é relevante, sobretudo, observar como o juízo universal da técnica - 'tal remédio é proveitoso para todos os fleumáticos' - depende de uma noção geral 'fleumáticos' - extraída indutivamente da comparação de casos semelhantes - isto é, da comparação de indivíduos de constituição física semelhante. Este processo indutivo, a epagogè, é descrito por Aristóteles nos Tópicos, I, 12, 105a10-20: "a indução consiste em partir dos casos individuais (kath'hékaston) para ascender aos enunciados universais (kathólou); por exemplo, se é verdadeiro que o melhor piloto é aquele que conhece, e que ocorre o mesmo com o melhor cocheiro, então, de uma maneira geral, o melhor em todo domínio é aquele que conhece". Devemos lembrar que o próprio Aristóteles nos alerta que os juízos proferidos pela tékhne não são dotados de uma universalidade e uma necessidade efetivas - tal como na ciência -, de modo que suas conclusões não são válidas para absolutamente todos os casos e sempre, mas, apenas, na maior parte das vezes - hos epi to polý. 
insiste, insurgindo-se contra a concepção exposta acima em linhas gerais, precisamente no trabalho da "diferença" presente tanto nas produções da natureza (exemplo usitado dos ovos ${ }^{16}$ ) como no que se ingere nos artifícios humanos (as cartas de Perrozet ${ }^{17}$ ), e mobiliza mesmo o paradoxo para firmar essa posição: "il n'est aucune qualité si universelle en cette image des choses que la diversité et varieté" (ibid.). A qualidade mais universal, o traço constante e de unidade, é precisamente a variedade e a diversidade que se encontram nas coisas e que as separam umas das outras; a semelhança é vencida pela diferença; a natureza possui como lei ("Nature s'est obligée", dirá algumas linhas depois) a produção do "dessemelhante".

Ora, as artes operam como se houvesse identidade efetiva entre os eventos que associam, dando, assim, um passo arbitrário. Relacionam um conjunto de ocorrências meramente semelhantes como "casos de um mesmo gênero" e, demarcado este universo, formulam regras de orientação ou de intervenção relativas aos casos observados e a todos os outros que a eles se assemelhem. E estão certas de que tais normas são capazes de orientar com segurança as operações futuras com os casos "do gênero". Montaigne assinala que esta certeza e segurança são ilusórias. "Nenhuma arte pode chegar à

16 "Et les Grecs, et les Latins, et nous, pour le plus expres exemple de similitude, nous servons de celuy des oeufs. Toutesfois il s'est trouvé des hommes, et notamment un en Delphes, qui recognoissoit des marques de difference entre les oeufs, si qu'il n'en prenoit jamais l'un pour l'autre" (ibid.).

17 “La dissimilitude s'ingere d'elle mesme en nos ouvrages; nul art peut arriver à la similitude. Ny Perrozet ny autre ne peut si soigneusement polir et blanchir l'envers de ses cartes qu'aucuns joueurs ne les distinguent, à les voyr seulement couler par les mains d'un autre." (ibid.) 
similitude" - diz o ensaísta - isto é, à inteira superposição, à identidade entre os casos relacionados (ainda que um hábil jogador se esforce muito polindo e limpando suas cartas, sempre haverá quem as distinga na passagem de uma mão a outra; jamais se ultrapassará os limites da mera semelhança). A arte não se dá conta de que as semelhanças, longe de assinalarem qualidades essenciais de um gênero (de manifestarem qualidades naturais) destacam-se no interior de um universo de singularidades que as sobredeterminam e comprometem, ou desviam, as conseqüências que acreditamos poder tirar delas: "La ressemblance ne faict pas tant un comme la difference faict autre. Nature s'est obligée à ne rien faire autre, qui ne fust dissemblable". Ora, sem poder alcançar os universais que alicerçariam o conhecimento, a arte também não pode garantir qualquer orientação segura para as atividades humanas, qualquer encadeamento certo de conseqüências. ${ }^{18}$ Ela oferece, pois, como prescrição certa o que não vai além de indicação incerta; como conhecimento, enunciados de generalidade vazia; como saber normativo, relações inseguras. Enfim - mostra Montaigne -, todo o esforço da arte, fundada na semelhança, para conferir segurança e certeza às suas práticas, para alicerçá-las em um conhecimento objetivo, é vão.

Em última análise, dilui-se a própria pertinência da oposição entre predicados essenciais e acidentais das coisas, sem que com isso se apaguem traços de semelhança entre elas. ${ }^{19}$ Semelhança que, em vez de apoiar o salto

${ }^{18}[\ldots]$ tout exemple cloche, et la relation qui se tire de l'experience est tousjours defaillante et imparfaicte; on joinct toutesfois les comparaisons par quelque coin. Ainsi servent les loix, et s'assortissent ainsin à chacun de nos affaires, par quelque interpretation destournée, contrainte et biaise. (id. ibid., p. 1070)

19 Será preciso dar atenção mais abaixo a este traço espantoso da própria constituição e 
para a universalidade de uma noção que reúne, subordina e permite julgar seguramente todos os casos, é antes da ordem de uma analogia sempre refutável, em que resta sempre algum elemento que é ocasião de ver de outro modo. ${ }^{20} \mathrm{E}$ da mesma forma que não se chega a uma essência como causa das produções constantes da Natureza, não se poderia igualmente pretender obter "efeitos universais" quando da tentativa de interferir na ordem das coisas naturais e humanas para mudar seu rumo, orientando-se pelas regras extraídas dos exemplos. Montaigne amplifica os traços de inconstância e irregularidade do mundo em sua argumentação, sobretudo para denunciar a ilusão da eficácia desta intervenção calcada em um saber das coisas exteriores.

Deve-se notar, ademais, que se há dificuldade em aceitar a "vaidade" da pretensão de interferir no domínio das coisas naturais (o corpo e a correlata pretensão presente na arte dos médicos, atacada adiante no texto), não há menos no domínio das coisas humanas (as leis para o indivíduo e para a cidade, isto é, o âmbito descrito tradicionalmente como "o das coisas que estão em nosso poder fazer e dependem de nossas deliberações e escolhas"). Nosso autor se ocupará de ambas: neste primeiro momento, porém, primordialmente

natureza das coisas com que Montaigne opera, esta "engenhosa mistura da natureza", nem totalmente dessemelhante, nem totalmente semelhante. (Cf. id. ibid., p. 1070: "Comme nul evenement et nulle forme ressemble entierement à une autre, aussi ne differe nulle de l'autre entierement. Ingenieux meslange de nature. Si nos faces n'estoient semblables, on ne sçauroit discerner l'homme de la beste; si elles n'estoient dissemblables, on ne sçauroit discerner l'homme de l'homme. Toutes choses se tiennent par quelque similitude.")

20 Cf. ibid., p. 1070; também p. 1066: em que Montaigne discute sempre haver a possibilidade para o juiz de diversa consideração de julgamento, dada a diferença entre os casos. 
e de modo muito mais enfático da última. O que enseja uma crítica de grande alcance e enraizada profundamente nos rumos da cultura humanista de sua época, cujos alicerces (a recuperação e atualização do legado dos antigos, o cultivo do comentário e da glosa, a cultura da imitação e emulação das vidas exemplares do passado, a erudição, etc.) serão, como veremos, sensivelmente afetados.

\section{A crítica da glosa e da interpretação}

Quem lê as primeiras páginas do $D a$ experiência, não se depara certamente com grande demora em ver os motivos lembrados acima serem desenvolvidos - motivos que estão, por assim dizer, dispersos e em grande medida latentes no texto. A estratégia eleita pelo ensaísta é diversa. Isto já se percebe no salto argumentativo - verdadeira mudança de registro, aparente, contudo - logo depois do início em que se insistia nas operações da diferença. Montaigne passa, então, a queixar-se das conseqüências dos que operam pressupondo a verdade e a eficácia do saber organizado a partir da semelhança - no limite, saber dogmático, vazio, que acaba por ganhar autonomia e expede seus juízos sem grande consideração pela particularidade do caso.

Isto porque a colocação inicial sobre a dessemelhança alicerça a crítica de Montaigne à tentativa do legislador ${ }^{21}$ de aperfeiçoar as leis e de afastar a liberdade de interpretação dos juízes quando da sua aplicação, referindo-as a

\footnotetext{
21 "Pourtant l'opinion de celuy-là ne me plaist guiere, qui pensoit par la multitude des loix brider l'authorité des juges, en leur taillant leurs morceaux." (Ibid., p. 1065)
} 
gêneros e espécies bem determinados de "casos" ou ainda buscando as suas especificações mínimas de modo a cobrir todas as suas particularidades. Logo de saída, vemos duas linhas de argumentação se desenvolver. E a primeira que nos é anunciada é a da liberdade de interpretação aberta pelo procedimento da especificação, via que ocupa praticamente todo 0 desenvolvimento da primeira parte e leva até as considerações mais enfáticas da imperfeição das leis humanas, testemunho da "imbecillitas" humana. Somente anunciada, Montaigne retorna e brevemente trata de frustrar a intenção do legislador com um expediente, este sim calcado claramente na dessemelhança natural, que poderíamos denominar por "argumento da desproporção", que opõe o número infinito de casos ao finito de leis. Examinemo-lo em primeiro lugar.

Qu'ont gaigné nos legislateurs à choisir cent mille especes et faicts particuliers, et y attacher cent mille loix? Ce nombre n'a aucune proportion avec l'infinie diversité des actions humaines. La multiplication de nos inventions n'arrivera pas à la variation des exemples. Adjoustez y en cent fois autant: il n'adviendra pas pourtant que, des evenemens à venir, il s'en trouve aucun qui, en tout ce grand nombre de milliers d'evenemens choisis et enregistrez, en rencontre un auquel il se puisse joindre et apparier si exactement, qu'il n'y reste quelque circonstance et diversité qui requiere diverse consideration de jugement. (Ibid., p. 1066).

Como se vê, o argumento opera - apoiando-se na premissa, posta anteriormente, de uma natureza que engendra sempre o dessemelhante - com 
a impossibilidade de vencer a distância entre a infinidade numérica dos casos e a necessária finitude, igualmente numérica, das leis presas aos casos discriminados e arrolados: "a multiplicação" - diz Montaigne - "não alcança a variação", a "infinita variedade das ações humanas" é desproporcional à capacidade e esforço humanos de multiplicar suas "invenções". Ora, o que pretendia o aludido legislador? Pensava que por meio da limitação da generalidade das leis - isto é, por meio da segmentação das leis gerais em um conjunto de leis cada vez mais discriminadas e específicas - poderia afastar, ou diminuir, o arbítrio da prática judiciária: "brider l'authorité des juges, en leur taillant leurs morceux". Ignora que esta pretensão é ilusória, pois é quase como querer deduzir a partir de um "universal" todo particular que se engendra no mundo. Dada sua singularidade, os casos futuros a serem julgados nunca serão adequadamente decifrados e tocados por qualquer formulação do corpo de leis - inevitavelmente geral, por específica que seja -, de modo que sua aplicação sempre exigirá a interpretação ${ }^{22}$ do juiz; exigirá sempre que ele vença a distância incontornável entre as prescrições das leis e as determinações próprias das ocorrências consideradas. Em outras palavras: especificar as leis, isto é, segmentá-las em múltiplas leis específicas, não elimina de modo algum - mostra Montaigne - o hiato existente entre sua necessária generalidade e a singularidade dos casos, produzida pela diferença. A arbitrariedade na aplicação das normas jamais é eliminada, pois se chegaria ao extremo da exigência de uma lei para cada caso julgado - um contra-senso, pois equivaleria à ausência de leis, à consagração do arbítrio.

22 "[...] il ne sentoit point qu'il y a autant de liberté et d'estendue à l'interpretation des loix qu'à leur façon." (ibid., p. 1065) 
E, como arremate deste argumento, por assim dizer, "quantitativo", o ensaísta acresce um outro, em que uma outra diferença, que assenta agora na diversa "qualidade" entre as leis ("fixas e imóveis") e os casos ("sempre em mutação"), vem afastar definitivamente a utilidade da "multiplicação das invenções": "Il y a peu de relation de nos actions, qui sont en perpetuelle mutation, avec les loix fixes et immobiles" (ibid., grifos nossos).

Melhor seria, então, diz Montaigne, que as leis fossem poucas, simples e gerais ("Les plus desirables, ces sont les plus rares, plus simples et generales", ibid., p. 1066), e que se procedesse como aquelas nações que tomam como juiz "um primeiro passante", ou qualquer um eleito em dia de feira, que decide ali mesmo, na hora, todos os seus processos ${ }^{23}$. Melhor seria se os chamados a

${ }^{23}$ A consideração dos casos limite das nações sem leis, ou reguladas somente pelas leis naturais, neste passo (logo depois de Montaigne alegar o estado de licenciosidade e liberdade dos juízes em uma França que tem mais leis do que as necessárias para regrar todos os mundos de Epicuro), contrapõe-se ao projeto de multiplicação das leis - que tem como corolário a multiplicação do comentário - e, se não configura exatamente a proposição da supressão de toda lei por parte de nosso autor, ao menos deixa clara a queixa contra um corpo especializado na lide com as leis, contra o círculo autônomo de jurisconsultos mais preocupados com "exemplos e precedentes" do que com julgar a especialidade dos processos em toda sua "acidentalidade". (Cf. loc. cit.: "Quel danger y auroit-il que les plus sages vuidassent ainsi les nostres, selon les occurrences et à l'oeil, sans obligation d'exemple et de consequence? A chaque pied son soulier.") Segundo Montaigne, a liberdade de interpretação de que desfrutam os juízes seria menos nociva para a aplicação das leis se eles se mantivessem presos à particularidade e às circunstâncias do caso que é julgado, evitando verificar se ele se enquadra no rol de casos anteriores julgados de determinada maneira (para os quais há uma interpretação cristalizada da lei) ou prever as conseqüências de suas decisões, o que não apenas amplia novamente o campo de interpretação (pois o caso pode ou não se enquadrar no grupo de casos para os quais já há jurisprudência, e ele pode ou não abrir 
julgar tomassem, se não nenhum parâmetro, ao menos princípios que fossem gerais e julgassem os casos segundo suas determinações próprias, distinguindo-as "à l'oeil", sem pretender identificá-los a casos anteriores, nem submetê-los às malhas das "invenções" jurídicas, "fixas e imóveis". Na medida em que o arbítrio do juiz sempre será necessário para relacionar o caso à generalidade da lei, é preferível preservar e respeitar seu espaço de deliberação a pretender limitar sua autoridade em nome de uma ilusória segurança e precisão da prática jurídica - calcada num corpo de leis que pretenderia determinar até as mais particulares ocorrências, como que tendendo a antes deduzi-lo do geral que a dar-lhe verdadeira atenção -, até mesmo porque a tentativa de tornar esta prática certa e "objetiva" amplia, como veremos, sua margem de incerteza e arbitrariedade, sobretudo, com o surgimento de uma nova necessidade.

Com efeito, tudo estaria bem em se tratando de procedimento inócuo, sem mais. No entanto, o que a denúncia da "multiplicação e divisão" aparentemente inocente do legislador aponta não é somente o esforço inútil de percorrer um espaço infinito, mas o efeito bem mais pernicioso da divisão, agora efetuada pela "altercação e querela", ensejadas pela abertura do campo da interpretação e da glosa, devido à própria multiplicação do escrito, do texto da lei. Aqui teremos a oportunidade de ver se insinuar, guiados pelo arrazoado montaigneano, uma nova diferença, de "entendimento", e um novo fracasso da "similitude": esforço de reencontrar, não inquirindo as próprias coisas, mas falando dos escritos de um outro, a sua inteligência primeira; esforço de uma

um novo precedente), mas também desvia o foco de atenção do juiz de seu objeto próprio - o caso - para discussões intermináveis de interpretação. 
fala segunda, que se volta para outra, e tenta dizer o mesmo. Matriz, aliás, da cultura de seu tempo, apoiada na glosa, no comentário erudito, na erudição livresca, que não escapa à mobilização freqüente da tópica que exige que se interrogue antes as próprias coisas, ao invés de laborar no rastro das palavras ditadas pela memória dos livros.

Montaigne trata especificamente o problema, atacando o procedimento da glosa jurídica, sem deixar de ampliá-lo para os domínios da religião (candente questão aberta pela remissão às escrituras proposta pelos reformados) e da glosa humanista (em sua busca de recuperar, comentar, interpretar e atualizar os conhecimentos legados pela historiografia, prosa oratória, poesia e filosofia moral antigas). Vejamos, mais detidamente, a crítica à glosa jurídica.

Segundo Montaigne, o detalhamento das normas, visando eliminar a arbitrariedade em sua aplicação, termina por aprofundar sua indeterminação e por aumentar o espaço do arbítrio dos juízes no julgamento dos casos. É o que ocorre, argumenta o ensaísta, com a legislação francesa ${ }^{24}$ e o que se passa ainda no exercício dessa "science, de sa nature, generatrice d'altercation et division": a jurisprudência. Procurando determinar e esclarecer o sentido da lei, sempre genérico e equívoco, os "escholiers de la jurisprudence" empenham-se

\footnotetext{
24 "nous avons en France plus de loix que tout le reste du monde ensemble, et plus qu'il n'en faudroit à reigler tous les mondes d'Epicurus (...) et si avons tant laissé à opiner et decider à nos juges, qu'il ne fut jamais liberté si puissante et si licencieuse." Lembremos que há uma passagem similar em Jean Bodin, República, VI, 6: “...il se cognoit à vue d'oeil que plus il y a des loix plus il y a des procès sur l'interpretation d'icelles: cela se peut voir en ce royaume qui a plus de loix et de coustume que tous les peuples voisins et plus de procès que toute le reste de l'europe...".
} 
em interpretá-la, em assinalar a intenção do legislador e os limites da aplicação da norma. Acabam, no entanto - mostra Montaigne -, não apenas não chegando ao fundo objetivo que se propunham alcançar, mas ainda ampliando a indeterminação e obscuridade da lei, pois a incerteza quanto ao sentido de seu enunciado aplica-se também a cada uma de suas interpretações ${ }^{25}$. O jurista tem a ilusão de que há um solo ao qual a reta interpretação da lei o conduzirá, que o discurso que ele apõe ao escrito lançará luz sobre este fundo. Procede como se houvesse uma compreensão inteiramente determinada da lei que, explicitada, tornaria a extensão de sua aplicação evidente por si mesma. Ocorre que este solo ao qual ele pensa poder chegar nunca é alcançado; mais do que isso: cada movimento em busca da determinação do sentido e da extensão ou alcance da lei, cada tentativa de conhecê-los, produz novos espaços para a dúvida, pede novas interpretações: "en subdivisant ces

${ }^{25}$ A dúvida a respeito de como julgar determinado caso poderia ser eliminada à medida que se recorresse ao histórico de julgamentos anteriormente proferidos por outros juízes em casos semelhantes, ou seja, pelo recurso à jurisprudência. Tal histórico compõe um parâmetro de orientação no julgamento presente e vai cristalizando, aos poucos, a maneira correta de se interpretar a lei em casos semelhantes. O problema é que o recurso a este histórico supõe a semelhança entre os casos. O que Montaigne diz é que, em vez deste recurso facilitar o julgamento do caso presente, ele dificulta, pois reabre a discussão a respeito do pertencimento ou não do caso presente ao conjunto de casos anteriores supostamente semelhantes. Mais do que isso, põe também como objeto de discussão a possibilidade do caso presente abrir um novo precedente - uma nova interpretação da lei. Nesta passagem, Montaigne se refere à tradição da glosa e do comentário do direito romano herdada pelo seu tempo e nomeia expressamente seus expoentes: "Nous doubtions sur Ulpian, redoutons encore sur Bartolus et Baldus. II falloit effacer la trace de cette diversité innumerable d'opinions, non poinct s'en parer et en entester la posterité." (Les Essais, p. 1067). 
subtilitez, on apprend aux hommes d'accroistre les doubtes; on nous met en trein d'estendre et diversifier les difficultez, on les alonge, on les disperse" (lbid., p. 1067.).

O argumento, como percebemos, é duplo: de um lado, o esforço do jurista em alcançar o sentido último da lei, por princípio inalcançável, é vão; de outro, a própria atividade a que ele se entrega produz obscuridade, afasta ainda mais o fundo objetivo almejado. Pois a análise, potência capaz de identificar e distinguir no objeto sutilezas e detalhes indefinidamente, expõe toda a complexidade e multiplicidade de significados que atravessa o texto, enquanto as interpretações que pretendem esclarecer seu sentido são igualmente incertas e interpretáveis, exigindo idêntico esforço de compreensão. A imagem a que Montaigne recorre para expor a vaidade da atividade do jurista é a das crianças que tentam pôr em ordem uma massa de prata viva, de mercúrio, e a vêem escapar por entre os dedos, perdendo a unidade e consistência que possuía de início, pulverizando-se ao infinito:

Qui a veu des enfans essayans de renger à certain nombre une masse d'argent vif? Plus ils le pressent et pestrissent et s'estudient à le contraindre à leur loy, plus ils irritent la liberté de ce genereux metal: il fuit à leur art et se va menuisant et esparpillant au delà de tout compte. C'est de mesme [...] (Ibid., p. 1066-7.)

Esta lógica que preside os esforços do jurista é estendida por Montaigne à glosa em geral, dominando igualmente as tentativas do reformador - na exegese das Sagradas Escrituras - e do humanista erudito - dedicado ao comentário dos escritos dos antigos. No primeiro nível de sua argumentação, 
Montaigne nos mostra que, em todos os casos, a interpretação não alcança o sentido próprio do texto, já que o campo em que se ela dá é vasto, amplo, aberto:

Et ceux là se moquent, qui pensent appetisser nos debats et les arrester en nous r'appellant à l'expresse parolle de la Bible. D'autant que nostre esprit ne trouve pas le champ moins spatieux à contreroller le sens d'autruy qu'à representer le sien, et comme s'il y avoit moins d'animosité et d'aspreté à gloser qu'à inventer. (lbid., p. 1066)

Nesta passagem, o ensaísta sugere que o texto sempre pode ser compreendido diferentemente, que as possibilidades de interpretação são múltiplas, que é sempre possível elaborar um outro 'contra-rol' do escrito, uma diferente rede de significações que igualmente espelhe seu sentido necessariamente diverso, equívoco. E isto porque a interpretação se dá (se nos for permitido traduzir em termos modernos o que Montaigne parece indicar) na relação, sempre instável e aberta, entre sujeito e objeto. De um lado, o texto sempre se apresenta de maneira relativa, de uma perspectiva determinada, um ângulo específico, nunca de modo absoluto, total. Em si mesmo, o escrito não é totalizável, sequer possui unidade, mas se apresenta como multiplicidade aberta de sentido. De outro, mostra o autor, o leitor é sempre diferente, os intérpretes nunca são os mesmos, nem sequer é o mesmo aquele que toma o texto em diferentes momentos no tempo: "Jamais deux hommes ne jugerent pareillement de mesme chose, et est impossible de voir deux opinions semblables exactement, non seulement en divers hommes, mais en mesme homme à diverses heures" (Ibid., p. 1068). Não havendo, pois, estabilidade e 
unidade do lado do sujeito nem do lado do objeto, as possibilidades de interpretação do escrito são inevitavelmente múltiplas.

Mas, o glosador - mostra-nos Montaigne, avançando para um segundo nível em sua argumentação - afasta mesmo o fundo objetivo do texto, obscurece sua compreensão, quando elabora seus comentários. Pois, por meio da análise, ele identifica e destaca sutilezas no texto, distingue detalhes, segmenta $o$ escrito em unidades de sentido e estas em unidades ainda menores, pulverizando-o numa multiplicidade de significantes. E cada um destes é igualmente objeto de dúvida, de modo que de uma questão, derivamse muitas: "en subdivisant ces subtilitez, on apprend aux hommes d'accroistre les doubtes; [...] En semant les questions et les retaillant, on faict fructifier et foisonner le monde en incertitude et en querelles" (Ibid., p. 1067.). A análise considera Montaigne - fragmenta o escrito "à l'infinité des atomes d'Epicurus", pondo em xeque sua unidade. Da mesma maneira, compromete sua coesão interna e sua forma: "Nous ouvrons la matière et l'espandons en la destrempant". Como uma peça de metal submetida em excesso ao fogo, o texto à mercê do comentário - ampliado, expandido, estufado pela análise perde sua têmpera, sua solidez e consistência. É seu próprio estatuto de objeto que a análise põe assim em questão - pois já não podemos falar de algo que não possua unidade nem certa coesão. De modo que é a própria inteligibilidade do escrito que é comprometida pela análise levada longe demais, que não se contenta com os resultados parciais que alcança, mas insiste em buscar o solo último, definitivo, o fundo objetivo do texto. É o que Montaigne nos mostra quando considera os juristas que obscurecem o sentido da lei à medida que se esforçam, mais e mais, por circunscrever com precisão a extensão de sua 
aplicação: a orientação vaga e pouco segura que ela oferecia de início revelase menos duvidosa que a trazida pelo esforço interpretativo:

Si ce n'est que les princes de cet art [...] ont tant poisé chaque sillabe, espluché si primement chaque espece de cousture, que les voilà enfrasquez et embrouillez en l'infinité des figures et si menues partitions, qu'elles ne peuvent plus tomber soubs aucun reiglement et prescription ny aucune certaine intelligence. Confusum est quidquid usque in pulverem sectum est. (Ibid., p. 1066.)

O comentário, portanto, afasta-nos da compreensão do escrito. Até porque - e, com esta consideração, o ensaísta passa para o terceiro nível de seus argumentos - também ele tem sua própria opacidade. O comentário pretende conduzir o leitor ao sentido próprio do texto, mas coloca-se entre ambos como um obstáculo a ser transposto, um escrito que também exige entendimento: "nous obscurcissons et ensevelissons l'intelligence; nous ne la descouvrons plus qu'à la mercy de tant de clostures et barrieres." [...] (Ibid., p. 1068-9) E cada novo comentário que se elabora é ainda mais sutil, refinado, complexo, abordando aspectos cada vez mais intrincados do escrito e exigindo do leitor um esforço cada vez maior de compreensão: "Le centiesme commentaire le renvoye à son suivant, plus espineux et plus scabreux que le premier ne l'avoit trouvé." (ibid., p. 1067)

Esta crítica que Montaigne assim dirige à glosa não poderia, no entanto, ser estendida à atividade do conhecimento em geral? É o que o ensaísta parece fazer, sugerindo que, em toda e qualquer investigação, a pretensão de se alcançar - por meio da análise - as determinações últimas da coisa - sua 
essência íntima - põe em movimento um processo de segmentação (de gêneros em espécies e de espécies em sub-espécies ${ }^{26}$ ) que, levado longe demais, desfaz a coesão interna e a própria unidade do objeto investigado:

[...] Je sçay mieux que c'est qu'homme que je ne sçay que c'est animal, ou mortel, ou raisonnable. Pour satisfaire à un doubte, ils m'en donnent trois: c'est la teste de Hydra. Socrates demandoit à Memnon que c'estoit que vertu: II y a, fit Memnon, vertu d'homme et de femme, de magistrat et d'homme privé, d'enfant et de vieillart. -- Voicy qui va bien! s'escria Socrates: nous estions en cherche d'une vertu, en voicy un exaim." (p. 1069)

Tratar-se-ia de uma crítica a uma verdadeira obsessão analítica na investigação, que não põe limites a seu poder de segmentação - uma busca vã, que não alcança o conhecimento da coisa, e em que, mais do que isso, o investigador permanece a girar em falso, enredado na teia das palavras, sem conseguir se livrar do registro do discurso para alcançar as coisas mesmas:

[...] Les hommes mescognoissent la maladie naturelle de leur esprit: il ne faict que fureter et quester, et va sans cesse tournoiant, bastissant et s'empestrant en sa besongne, comme nos vers de soye, et s'y estouffe. Mus in pice. (ibid.,p. 1068)

[...] Nostre contestation est verbale. Je demande que c'est que nature, volupté, cercle, et substitution. La question est de parolles, et se paye de mesme. Une pierre c'est un corps. Mais

\footnotetext{
${ }^{26}$ Não esqueçamos de que o pensamento de Montaigne tem como contexto histórico a França do século XVI, em que prevalecia ainda em grande medida o modelo aristotélico de ciência.
} 
qui presseroit: Et corps qu'est-ce?--Substance, --Et substance quoy? ainsi de suitte, acculeroit en fin le respondant au bout de son calepin. (Idem, p. 1069)

Esta concepção nominalista ${ }^{27}$ da ciência, que Montaigne subrepticiamente introduz no fio de sua argumentação, é correlata ao que foi dito a respeito da glosa. Pois, assim como os comentários revelam-se obstáculos entre o leitor e o texto que pretendiam esclarecer, as palavras afastam, em vez de aproximar, o investigador das coisas. Isto não significa, no entanto, que o juízo de Montaigne a respeito da ciência é o mesmo que acerca da glosa. Pois, se, na ânsia de alcançarmos as coisas, condenamo-nos ao universo das palavras - "On eschange un mot pour un autre mot, et souvent plus incogneu" é somente na glosa que a relação com o conhecimento é de fato corrompida relação em que deixamos as coisas para buscar palavras com que designar outras palavras: "Il y a plus affaire à interpreter les interpretations qu'à interpreter les choses, et plus de livres sur les livres que sur autre subject: nous ne faisons que nous entregloser." (Ibid.,p.1069)

Antes de analisarmos, contudo, a crítica de Montaigne à cultura da erudição, dos comentários sobre comentários, é necessário que

\footnotetext{
${ }^{27}$ No exercício da ciência - afirma explicitamente Montaigne nesta passagem - substituímos uma palavra por outra, um signo por outro, que também tem sua opacidade. E frequentemente a substituição da palavra se faz em favor de várias outras ainda mais desconhecidas, de modo que a operação tende sempre a multiplicar as dúvidas, aumentar a obscuridade. Furtamo-nos a investigar mais a fundo esta concepção no presente estudo, não apenas porque sua menção neste ensaio é lateral e muito breve, mas, principalmente, porque a ausência desta investigação não compromete em nada a leitura de Da experiência.
} 
compreendamos um pouco melhor suas considerações sobre a investigação científica. Pois, Montaigne não ataca a busca do conhecimento enquanto tal que, pejorativamente, chamamos de obsessão analítica. Nem poderia fazê-lo, já que reconhece - acompanhando Aristóteles e toda uma tradição - que se trata de uma afecção - um desejo, uma paixão - inerente à condição humana: "Il n'est desir plus naturel que le desir de connoissance." (Ibid., p.1065) [...] "Les hommes mescognoissent la maladie naturelle de leur esprit: il ne faict que fureter et quester..." (Ibid., p. 1068). A procura incessante pelo conhecimento mostra Montaigne - é apenas sinal de vitalidade, de adesão a esse páthos intelectual que nos move, esse desejo que nos lança adiante, em busca de mais e mais: "Nul esprit genereux ne s'arreste en soy: il pretend tousjours et va outre ses forces; il a des eslans au delà de ses effects; s'il ne s'avance et ne se presse et ne s'accule et ne se choque, il n'est vif qu'à demy" [...] (Ibid., p. 1068) E é sinal de virtude - grandeza de alma, generosidade, força. Pois, o vício mostra Montaigne - não está em procurarmos incessantemente pelo conhecimento, mas em abandonarmos a busca, que não chegara a seu fim: "Ce n'est rien que foiblesse particuliere qui nous faict contenter de ce que d'autres ou que nous-mesmes avons trouvé en cette chasse de cognoissance; un plus habile ne s'en contentera pas." [...] (Ibid.) Abandonando-a por contentamento, satisfeitos com o que conquistamos (pretenso conhecimento que apenas revela o quanto ainda ignoramos), expomos nossa alma pequena, que precisa de pouco para se satisfazer ("C'est signe de racourciment d'esprit quand il se contente, ou de lasseté") ou fraca, que não se dispõe ao esforço, ao sofrimento, ao sacrifício por mais; ou ainda mesquinha: não com os outros, mas consigo mesma, proibindo-se de buscar mais, de querer mais, forçando-se 
ao contentamento com o já conquistado. A virtude, na relação com 0 conhecimento, está em buscá-lo incessantemente, em reconhecer, sempre e novamente, que ele ainda não foi alcançado, que é necessário ir mais além: "II y a tousjours place pour un suyvant, ouy et pour nous mesmes, et route par ailleurs. [...] II n'y a point de fin en nos inquisitions; nostre fin est en l'autre monde." (ibid.)

Mas, por que há virtude nesta zetética, nesta pesquisa incessante - e não vaidade? Ora, porque, ainda que o conhecimento não seja alcançado mas permaneça como mero horizonte cuja função é pôr a investigação em movimento -, produz-se, no exercício da própria busca, a formação intelectual e moral daquele que a realiza. $\mathrm{Na}$ investigação - como veremos explicitar-se mais adiante -, o espírito se prepara e ordena para todo novo enfrentamento. Cada investida feita em direção à ciência - cada juízo emitido acerca das coisas -, exercita sua capacidade de julgar - e, ao mesmo tempo, alerta-o de que sua ignorância persiste - forçando-o a abandonar toda sorte de arrogância. É isto o que faz da busca do conhecimento o seu próprio fim: ela é formadora; constitui as disposições moral e intelectual do sujeito, sua "suffisance" e seu caráter. Nosso alimento - aquilo que nos move -, diz Montaigne, não deve ser o conhecimento, mas a própria investigação; mais que a presa, interessa a caça.

Nesse sentido, a crítica que o ensaísta empreende neste momento do ensaio refere-se menos ao procedimento analítico enquanto tal e mais à sua aplicação irrestrita ao comentário de textos, à glosa, que deixa o exame das coisas para ocupar-se somente de saberes alheios. Limitando-se a tentar esclarecer os textos das leis ou dos clássicos, iluminar o que foi dito por autoridades do passado - sem questionar ou confrontar seu saber - o glosador 
deixa de exercitar seu juízo, de "frotter et limer [sa] cervelle contre celle d'autrui" (Les Essais, De I'Institution des Enfans, p. 153). O alvo mais amplo da crítica do ensaísta, aqui, é a cultura humanista de seu tempo, a erudição que assume o lugar do saber, a ciência identificada com os textos dos autores do passado. "Tout fourmille de commentaires; d'auteurs, il en est grand cherté", diz Montaigne. Pois, se todo o conhecimento é buscado nos clássicos, o comentário com vistas a esclarecê-los assume o lugar preponderante como instrumento da cultura, e a autoridade dos antigos toma o lugar do crivo próprio do investigador:

[...] Le principal et plus fameux sçavoir de nos siecles, est-ce pas sçavoir entendre les sçavans? Est-ce pas la fin commune et derniere de tous estudes? Nos opinions s'entent les unes sur les autres. La premiere sert de tige à la seconde, la seconde à la tierce. Nous eschellons ainsi de degré en degré. Et advient de là que le plus haut monté a souvent plus d'honneur que de mérite; car il n'est monté que d'un grain sur les espaules du penultime. [...] (p. 1069)

Como se vê, nem mesmo a contribuição daquele "que subiu mais alto" é vista como elemento positivo no modo de transmitir e fazer avançar o domínio do saber. Este deixa de buscar o saber por si mesmo e, pensando poder tomá-lo quase todo de empréstimo, permanece de mãos vazias, enredado nas teias da interpretação. A erudição, que pretende beneficiar-se de um saber alheio, é um saber vazio, pois não apreende as coisas, as matérias em causa, e não alcança sequer o sentido dos textos de que se apropria, não chegando nunca à sua suposta objetividade. 
Mas, o núcleo mesmo da crítica montaigneana à cultura do comentário, neste momento do ensaio, é menos o vazio da erudição em que ela redunda e mais as conseqüências práticas de sua obsessão analítica, que gera - acerca das leis e dos textos eclesiásticos, por exemplo - dissenso, querelas e sedição. Como o próprio contexto histórico do autor nos ajuda a compreender, o esforço de juristas e teólogos na exegese das leis e das Escrituras, sua pretensão de alcançar o sentido próprio do escrito e estabelecer o consenso a seu respeito, teve efeitos funestos: "J'ay veu en Alemagne que Luther a laissé autant de divisions et d'altercations sur le doubte de ses opinions, et plus, qu'il n'en esmeut sur les escritures sainctes." A análise de tais textos, estabelecendo distinções, produziu somente dissenso, discórdia e querelas de interpretação, que culminaram em guerras e sedição. É justamente neste terreno - o da prática - que a crítica de Montaigne às artes e à sua pretensão de objetividade mais se aprofunda. É exatamente o que veremos na próxima seção do estudo.

\section{A imperfeição das leis humanas e a inapreensibilidade das leis naturais}

A crítica de Montaigne à glosa no âmbito da jurisprudência, como vimos na seção anterior, não se refere apenas à vaidade de sua busca. Deve-se ainda a algo mais que isso. $O$ que está fundamentalmente em questão para o ensaísta é o fato, bem mais grave, de ela encerrar os homens num mundo de dogmas, levando-os a operar com eles a cada vez que devem julgar. E o horizonte de seu esforço de racionalização e controle dos juízos particulares que não retira os homens da esfera da opinião, mas apenas os faz crer ter dela saído - termina sendo a atenção à pura forma da lei. E, com o formalismo, a arte jurídica assume toda a sua face violenta. Pois, se toda submissão de 
casos particulares e circunstanciados a normas gerais fixas já é, por princípio, uma forma de violência - como veremos nos exemplos da medicina -, o formalismo leva-a às suas últimas conseqüências quando inverte a lógica que levou inicialmente à elaboração da técnica, tornando a manutenção da racionalidade da forma prioritária em relação à solução dos problemas empíricos particulares. Esta inversão perniciosa parece ser o limite a que chega a razão técnica. Inicialmente formulada para dar racionalidade às práticas, retirando delas, por meio da justificação racional dos procedimentos adotados, todo traço de arbitrariedade, a técnica aos poucos adquire, por meio de sua ânsia de controle, uma pretensão arquitetônica e totalizante, capaz de suprimir todo traço de contingência e particularidade em nome da manutenção da racionalidade formal do todo. Seu esforço em eliminar de seu seio todo traço de arbitrariedade faz, pois, as técnicas voltarem-se para si mesmas e zelarem, antes de tudo, pela racionalidade de suas formas.

Mas, antes de chegar aos últimos desdobramentos da aspiração técnica de controle, Montaigne mostra ser impossível que normas gerais regulem com equidade condutas tão diferentes, tão singulares: "ce n'est pas merveille si celles qui gouvernent tant de particuliers" sejam tão difíceis de estabelecer ("dresser") (Cf. ibid., p. 1070). Assim, à impossibilidade de determinar com segurança sua compreensão e a extensão de sua aplicação, juntam-se seu descompasso necessário em relação aos casos, a resistência da singularidade destes às suas formulações genéricas. Para prová-lo, Montaigne aponta as contradições e erros da justiça - inclusive da França de seu tempo -, sua incapacidade para atingir os fatos a que se volta na sua materialidade e complexidade próprias, verdadeiro testemunho da fragilidade humana: 
[...] Considerez la forme de cette justice qui nous regit: c'est un vray tesmoignage de l'humaine imbecillité, tant il y a de contradiction et d'erreur. Ce que nous trouvons faveur et rigueur en la justice, et y en trouvons tant que je ne sçay si l'entredeux s'y trouve si souvent, ce sont parties maladives et membres injustes du corps mesmes et essence de la justice. [...] (ibid., p. 1070.)

A arte jurídica, buscando fazer justiça, produz apenas favor ou rigor: ou é complacente demais, não punindo quem deve ser punido, ou rigorosa demais, condenando inocentes. Sua balança oscila entre estes extremos, sem nunca encontrar o ponto da mediania, o equilíbrio da justiça: "Ce que nous trouvons faveur et rigueur en la justice, et y en trouvons tant que je ne sçay si l'entredeux s'y trouve si souvent, ce sont parties maladives et membres injustes du corps mesmes et essence de la justice." (Ibid.). E não se trata de um traço que the seja acidental, diz Montaigne, e sim de uma fragilidade essencial, já observada, aliás, pelos antigos: se, como sustentam os estóicos, "nature mesme procede contre justice, en la plus part de ses ouvrages", que dizer das leis que os homens arbitrariamente elaboram?

As leis são fruto do arbítrio humano, sustenta Montaigne: não têm um fundamento metafísico; não procedem da Justiça. São sujeitas às imperfeições de seus autores, vãos e incertos, freqüentemente tolos e, mais ordinariamente ainda, iníquos. É por isso que não há nada tão ampla e gravemente faltoso como as leis, nem tão habitualmente; elas não se separam da injustiça. E as leis francesas, segundo o ensaísta, constituem um caso paradigmático dessa precariedade: 
[...] Les nostres françoises prestent aucunement la main, par leur desreiglement et deformité, au desordre et corruption qui se voit en leur dispensation et execution. Le commandement est si trouble et inconstant qu'il excuse aucunement et la desobeyssance et le vice de l'interpretation. [...] (Ibid., p. 1072.)

São desajustadas, disformes; seus comandos, confusos e inconstantes - o que termina por justificar os erros dos juízes em sua interpretação e aplicação, a desordem e corrupção em sua dispensa e execução. A mesma desorientação alcança os cidadãos, cuja desobediência e inobservância a tais normas malseures tornam-se compreensíveis.

Se os homens recorrem às leis em busca do justo, eles alcançam, no entanto, apenas as próprias leis, nunca a justiça. A ausência de um fundo metafísico nas leis faz com que prevaleçam entre eles as 'fórmulas da justiça':

[...] Or les loix se maintiennent en credit, non par ce qu'elles sont justes, mais par ce qu'elles sont loix. C'est le fondement mystique de leur authorité; elles n'en ont poinct d'autre!. [C] Qui bien leur sert. Elles sont souvent faictes par des sots, plus souvent par des gens qui, en haine d'equalité, ont faute d'equité, mais tousjours par des hommes, autheurs vains et irresolus. II n'est rien si lourdement et largement fautier que les loix, ny si ordinairement. [B] Quiconque leur obeyt parce qu'elles sont justes, ne leur obeyt pas justement par où il doibt. (Ibid., p. 1072.)

O reconhecimento da ausência de vínculo entre as leis e a Justiça não leva Montaigne, todavia, a defender sua desobediência. Se a legitimidade e 
autoridade das leis não vêm do fato de serem justas - isto é, deduzidas da idéia de justiça ou elaboradas a partir do conhecimento do justo -, vêm, no entanto, da pura autoridade que têm enquanto leis estabelecidas. Fruto do arbítrio humano, elas devem ser observadas porque constituem e garantem o vínculo possível entre os homens, reunindo-os em sociedades políticas. O fundamento da obediência que lhes devemos reside nelas próprias, em sua pura função de autoridade e de comando político. Mas isto não significa, certamente, que se deva obedecê-las de maneira cega. É preciso ter sempre em vista sua fragilidade e arbitrariedade. Esta consciência confere à obediência às leis algum distanciamento crítico ou certa adesão distanciada. O próprio fato de não tomá-las como absoluto faculta a Montaigne manter e guardar a exigência e a liberdade internas da interrogação constante sobre o valor e a legitimidade das leis, embora permaneça o imperativo da obediência exterior a elas em sua mesma imperfeição. "I'I n'y a remede”, diz, a não ser subtrair-se ao seu jugo pela obediência que folga em não ser sequer tocada pela lei, como parece sugerir: "L'indemnité n'est pas monnoye suffisante à un homme qui faict mieux que de ne faillir point." (Ibid.) Ou ir buscar incontinenti outras em outro $\operatorname{lugar}^{28}$

Em se tratando de uma justiça puramente formal, na qual a absolvição ou condenação não dependem da inocência ou culpa efetivas do réu, mas apenas da capacidade de seu advogado, Montaigne diz que, sabendo-se

\footnotetext{
${ }^{28}$ Cf. Ibid., p. 1072, todo parágrafo em que discute seu grande apego à liberdade e agradece a Deus por não ter sido interpelado por juiz na posição de juiz, nem recebido em prisão, e lamenta a condição daqueles que se acham impedidos de ir e vir por ter-se voltado contra as leis. Villey nos lembra em nota, que pouco tempo mais tarde, em julho de 1588, Montaigne permaneceria preso pelos da "Liga", oito horas, na Bastilha.
} 
inocente, jamais se apresentaria diante de homem que decidisse acerca de sua cabeça. Até porque, para um homem que faz melhor do que não errar, o risco não vale a pena, visto que é uma justiça que apenas pune, e da qual o máximo que se pode esperar é a absolvição. Submetendo-se-Ihe, Montaigne somente teria a perder: ou perderia a vida, ou, na melhor das hipóteses, sua honra seria maculada. Para este homem, de fato, somente valeria a pena submeter-se ao julgamento da lei se, como na China, houvesse a possibilidade de compensação pela correção dos atos - justamente o que indicaria o equilíbrio na balança da justiça. Não sendo este o caso na França, Montaigne diz que agiria diferentemente de Sócrates: ameaçado pelas leis do país, e sabendo-se inocente, faria como Alcibíades: correria, como dissemos, em busca de outras. Mas sempre sem a ilusão de poder viver humanamente fora do abrigo das leis, ou de opôr as que temos, imperfeitas, à Justiça ${ }^{29}$. Não se vê traço de uma iniciativa de "correção" das imperfeições, senão pela ordenação propiciada pela volta a si (pelo reconhecimento de sua ignorância, pela afirmação constante da inconstância e da incerteza nas conduções tanto da própria vida, como mais ainda na de muitas em conjunto, que sofrem incessantemente a intervenção da fortuna), o que acaba por constituir advertência suficiente e que aponta para algum proveito, como estudaremos à frente. Neste sentido, podemos dizer que a distância estabelecida pela interrogação reflui sobre o domínio público e permite a moderação e certa

\footnotetext{
${ }^{29} \mathrm{O}$ caso extremo que encontramos tratado no primeiro capítulo do terceiro livro, "De l'utile et de l'honneste", do monarca que, somente em situação de salvação pública de sua nação, poderia incorrer numa quebra de obediência, ainda sim lamentando-se por tê-lo feito, não constituiria instância que infirmasse essa orientação ao "loyalisme" e a obediência, em rigor, geral nos Ensaios. Nem mesmo a "evasão" aludida acima.
} 
maleabilidade na aplicação das leis, que a relação dogmática não proporcionava. Isto certamente não dependeria da experiência em sua relação com as coisas exteriores, nem no saber que ela supostamente estaria apta a fundar. Não é daí que Montaigne pensa extrair seu "proffict", nem instruir sua "institution":

[...] Quel que soit donq le fruict que nous pouvons avoir de l'experience, à peine servira beaucoup à nostre institution celle que nous tirons des examples estrangers, si nous faisons si mal nostre proffict de celle que nous avons de nous mesme, qui nous est plus familiere, et certes suffisante à nous instruire de ce qu'il nous faut. (Ibid., p. 1072.)

A reorientação para a experiência de si impõe um novo programa de estudos. “Je m'estudie plus qu'autre subject. C'est ma metaphisique, c'est ma phisique" (Ibid.). Antes de passar a ele, contudo, é preciso uma última consideração sobre as leis, agora não mais as humanas, mas as naturais aquelas que os filósofos pensam ter descoberto e as quais nos remetem para a ordenação das nossas condutas: "les philosophes, avec grande raison", diz Montaigne, "nous renvoyent aux regles de Nature". Mas, acrescenta ironicamente, elas "n'ont que faire de si sublime cognoissance", pois seu esforço em busca deste conhecimento produz, inevitavelmente, um saber falsificado. Toda Física, isto é, toda exposição das leis de natureza na forma de uma teoria, necessariamente as "falsifica", apresenta "son visage peint trop haut en couleur et trop sophistiqué", dando grandiosidade e complexidade a algo que, no fundo, é simples. Toda teorização sobre a ordem da natureza mostra Montaigne - apresenta-a alterada, e é por isso que "naissent tant de 
divers pourtraits d'un subject si uniforme". Tal diaphonia - diversidade de discursos de valor equivalente a respeito do mesmo assunto - mostra, então, que nenhum deles constitui conhecimento efetivo, e servem somente de alimento para nossa curiosidade.

Assim, quando Montaigne diz que devemos "[nous] commettre à nature", ele não quer dizer que devemos nos orientar pelo conhecimento de suas leis - saber "ingenieuse, robuste et pompeuse" -, mas conduzir-nos "naïvement et ordonnéement", entregando-nos "le plus simplement" a ela, ignorantemente e sem curiosidade. Já que não podemos conhecer as normas que a regem - e mesmo que pudéssemos, este saber não as faria "changer de route", não faria leis que são gerais e comuns se aplicarem de modo diferente a nós -, devemos nos deixar levar por elas, sem conhecê-las e sem nos preocuparmos com isso, como faz o próprio autor: "je me laisse ignoramment et negligemment manier à la loy generale du monde"30. Sem acesso às regras

\footnotetext{
${ }^{30}$ Poderia surpreender que algumas páginas depois de ter insistido tanto no que chamamos "trabalho da diferença" Montaigne agora nos ofereça esta pintura de uma Natureza regrada necessariamente por leis semelhantes, públicas e comuns, não fosse o caráter antitético daquela primeira argumentação. Se insiste lá numa Natureza que produz constantemente o dessemelhante, o que parece incompatível com esta "loy generale du monde" - a que se deixa manejar, mas que não pretende conhecer, nem muito menos fazer, possuindo um saber dela, mudar de rumo -, é para contrapô-la à pretensão do saber dogmático da jurisprudência em regrar as condutas humanas a partir de si com segurança. Vale enfatizar que desde o início do capítulo notamos a presença de uma figura arguta, judiciosa e hábil (o homem de Delfos que distingue os ovos, o jogador experiente que reconhece o verso das cartas) que, este sim, é capaz de desestabilizar o saber incerto dos sçavants com sua capacidade de fazer distinções. Não se trata, pois, de afirmação de cunho físico ou metafísico, acerca da desordem e instabilidade do mundo, mas de produzir diaphonía.
} 
que governam o mundo, devemos nos "descharger du soing de son gouvernement", confiando na sabedoria da natureza, na bondade e capacidade de seu governante.

Mas, em que consiste propriamente a conduta "en celuy qui a l'heur de sçavoir s'employer [...] naturellement", em quem sabe entregar-se à "prudence" que possui a Natureza para nos guiar na vida, tal como nos dotou de pés para andar? Deixar-se manejar ignorantemente e negligentemente pela natureza, parece descartar uma concepção de "lei natural", que teria para o Homem um caráter normativo, tal como a descreve a tradição estóica - que pretendia conhecê-la para poder "habitá-la" pela vontade, coincidindo com a necessidade que impera em todo recanto do Mundo, conformando-se-Ihe e esposando-a pela vontade. Assim como uma outra, em que a inserção do homem no mundo, dotado de um saber de suas leis, propicia, ao menos em uma parcela deste, certa possibilidade de intromissão e modificação. Montaigne alega, porém, que esta lei "ne se diversifiera pas pour [lui]". Eis a loucura dos homens que sofrem por isso. Tais invenções, em sua sofisticação, são acusadas, não apenas por sua "falsidade", mas por sua inutilidade.

Também, e este talvez seja o ponto principal, pelo caráter de regulação imposta do exterior que esta "norma", supostamente conhecida, comporta. Não é outro o caso da jurisprudência atacada até aqui, nem o será o da medicina. Todas pretendem regular as condutas a partir de um modelo estável e imposto de fora. Trazendo o perigo, denunciado veementemente por Montaigne nestas últimas páginas de seus Ensaios, de subtrair a liberdade do sujeito que a elas se submete de maneira inflexível e definitiva. Este seu traço mais contundentemente funesto. 
Daí Montaigne propor-nos uma reorientação reflexiva da experiência. Seu primeiro passo é o reconhecimento da ignorância acerca dos acontecimentos e eventos exteriores e a recusa de toda regulação a partir de um saber que se impõe igualmente do exterior, e é experimentado como violência.

Assim, o autor se recusaria a propor-nos que fundamentemos nossas condutas sobre o conhecimento das causas por meio das quais a natureza opera - isto é, sobre a ciência das leis naturais, como pretendem os filósofos -, para propor-nos que as assentemos na observação de seus efeitos sobre nós. Deslocaria o fundamento da moral, portanto, do conhecimento da natureza para a observação de nós mesmos. Ora, não é exatamente isto o que ele faz? Ele não diz que se estuda "plus q'autre subject", e que este estudo é sua "metafísica" (seu saber fundante) e sua "física" (a 'ciência' em que busca os parâmetros para suas ações)? De fato, a experiência "que nous tirons des exemples estrangers" dificilmente serve para nossa "institution", isto é, dificilmente nos orienta, já que a cristalizamos na forma de leis arbitrárias que somente produzem injustiça, ou a deturpamos, elaborando um conhecimento falso acerca dos eventos naturais. Assim, devemos recorrer à experiência "que nous avons de nous mesme, qui nous est plus familiere, et certes suffisante à nous instruire de ce qu'il nous faut". Na medida em que as leis da arte e as leis da natureza não podem orientar nossas condutas, devemos buscar em nós mesmos o parâmetro de nossas ações. 


\section{Capítulo 2 - A Orientação Moral pela Experiência}

\section{As Artes de Viver e a Experiência de Si}

No primeiro movimento do ensaio, Montaigne inicia a desqualificação que alicerça o conjunto do texto - de toda pretensão a um saber normativo referido às condutas humanas, apontando a impossibilidade de nos orientarmos seja pelas leis humanas - que não nos levam à justiça - seja pelas leis da natureza - que nos são desconhecidas. No presente movimento, ele desqualificará a pretensão das "artes da vida", fundadas no acervo de exemplos morais legados pela história, a forma paradigmática da ética cultivada pelos humanistas ${ }^{31}$. Em oposição às noções genéricas e abstratas com que operam estas artes, às suas figuras exemplares, o ensaísta apontará a experiência de si como o único saber capaz de orientar, de alguma forma, nossas ações, sempre singulares e circunstanciadas, referidas sempre a situações particulares e matérias (afetivas) diversas.

As artes de viver e as coleções de relatos, adágios, florilégios de exemplos, que seu tempo cultiva mobilizam "formas" ou noções gerais (humores, caracteres, condições, tipos de vida, afetos, disposições, com suas qualidades essenciais) que Ihes permite identificar e nomear a multiplicidade dos casos particulares, construir classificações e inferir leis a partir dos casos observados. Operam, enfim, com a pretensão de constituir um verdadeiro

\footnotetext{
${ }^{31}$ Estas artes da vida referem-se a preceitos de regulação e orientação da vida ordinária, na tradição do que é realizado pelos manuais estóicos ou ainda pelo De Officiis, cuja importância
} 
conhecimento da moralidade (com seus "objetos" próprios, suas noções gerais, seus modelos, casos paradigmáticos e prescrições de comportamento), análoga à física dos filósofos (com seus gêneros, espécies, e sua referência a uma metafísica das substâncias), que seu século começa a fazer vacilar. Montaigne recusa-se, enfim, a referir a orientação das ações a estes conhecimentos e afronta diretamente a tradição assumida por seu tempo, assinalando suas pretensões como vãs e infundadas: "Non seulement je trouve mal-aisé d'attacher nos actions les unes aux autres, mais chacune à part soy je trouve mal-aisé de la designer proprement par quelque qualité principalle, tant elles sont doubles et bigarrées à divers lustres" (Essais III 13, p. 1076-7). Não podemos identificar com segurança nossas afecções e disposições, nossos movimentos internos; não podemos determiná-los, conhecê-los: "Je laisse aux artistes, et ne sçay s'ils en viennent à bout en chose si meslée, si menue et fortuite, de ranger en bandes cette infinie diversité de visages, et arrester nostre inconstance et la mettre en ordre" (ibid.). Devido à complexidade $e$ indeterminação de nossas afecções e disposições, toda tentativa de predicá-las -- 'tal ação é corajosa', 'temperante' ou 'justa' - apenas designa um dentre tantos traços possíveis; permite, no máximo, a identificação de alguma semelhança em relação a outras, de modo algum a identificação de um gênero ou de uma "essência". E isto ocorre não apenas no registro dos movimentos internos do agente moral mas no que diz respeito a ele próprio:

[...] Ce qu'on remarque pour rare au Roy de Macedoine Perseus, que son esprit, ne s'attachant à aucune condition,

na constituição da cultura humanista é bastante conhecida. Cícero escreve seu livro, segundo diz, "ad intitutionem vitae communis", e não em vista da constituição de uma Ciência da ética. 
alloit errant par tout genre de vie et representant des moeurs si essorées et vagabondes qu'il n'estoit cogneu ny de luy ny d'autre quel homme ce fust, me semble à peu pres convenir à tout le monde. (ibid.)

A equivocidade que encontramos em nossos afetos e disposições, também se assinala, pois, na identificação do caráter dos indivíduos, que variam de uma disposição psicológico-moral a outra, de um comportamento a outro, sem nunca se fixar em nenhuma "assiette" estável, identificável, cognoscível. Assim como a predicação de uma ação ou paixão, também a dos agentes 'melancólico', 'virtuoso', 'corajoso', 'temperante' ou 'justo' -- não equivale à apreensão de seu ser, ao seu conhecimento.

Assim, as noções gerais e paradigmas das artes de viver não podem orientar nossas condutas com nenhuma segurança, já que toda tentativa de fazer nossas ações corresponderem às suas abstrações alcançará, no máximo, algum traço de semelhança entre a noção geral e o caso, nunca uma efetiva correspondência entre ambos. E, se de um lado, tais hipóstases de traços parciais destacados de um conjunto de casos assinalam semelhanças, também obscurecem e mascaram sua singularidade; apagam suas diferenças e especificidades. E mesmo os exemplos morais legados pela história (que foram um dia casos concretos, ações particulares de personagens reais, determinados) mostram-se inutilizáveis para preencher as funções que lhes damos -- segundo o adágio da historia magistra vitae --; pois, não só apresentam múltiplas determinações diversas daquelas dos casos a que são referidos, como se tornam meras abstrações quando, pelo isolamento de algum ou de alguns de seus inumeráveis aspectos, são transformados em 
paradigmas de conduta.

É, portanto, esta crítica da ilusão essencialista das artes morais e da abstração do caminho da exemplaridade e ainda a exigência que lhe é correlata da consideração da particularidade das situações e da singularidade dos casos - a exigência de sua apreensão concreta, viva e encarnada - que levará o ensaísta a afastar os paradigmas externos para voltar-se para si mesmo, a buscar na experiência de si, na inspeção minuciosa das condições e matérias singulares de sua ação, alguma orientação para suas condutas:

[...] Quel que soit donq le fruit que nous pouvons avoir de l'expérience, à peine servira beaucoup à nostre institution celle que nous tirons des exemples estrangers, si nous faisons si mal nostre proffict de celle que nous avons de nous mesme, qui nous est plus familiere, et certes suffisante à nous instruire de ce qu'il nous faut. (ibid., p. 1072)

Trata-se, pois, de passar do externo para o interno, do exemplo para a experiência: "La vie de Caesar n'a poict plus d'exemple que la nostre pour nous; et imperière, et populaire, c'est toujours une vie que tous accidents humains regardent" (ibid., p.1073) . É melhor, mais produtivo e eficaz, buscar instrução moral em si mesmo que nos livros: 'j'aymerois mieux m'entendre bien em moy qu'en Ciceron" (ibid.) (cujo belo tratado De Officiis, estofado de exemplos e casos paradigmáticos, deduz das inclinações naturais do homem as virtudes e as prescrições de comportamento).

Todo saber prático provém desta experiência. Estudar-se, examinar-se, observar as "legeres occasions qui l'on remué d'un estat à l'autre"(ibid.). Escutar-se e auscultar-se, "espier de pres les effects et circonstances des 
passions qui le regentent" (ibid.) é o que se impõe ao agente na ausência de qualquer saber prévio sobre a natureza destes afetos e sobre as disposições que os dirigem. A experiência procede fundamentalmente da inspeção destes movimentos internos do sujeito. Ela os apreende na complexidade de suas manifestações vivas, na sua plenitude sensível: "par vray sentiment, non par discours", dirá o ensaísta mais adiante ${ }^{32}$. Não se trata mais de submeter os fenômenos internos à malha das noções gerais operada pelo intelecto, mas de armazená-los na memória, que os retém de forma plena, como vivências.

É certo que Montaigne, como bem sabemos, é um crítico tenaz dos empreendimentos de formação dos jovens alicerçados na memória e na erudição livresca, responsáveis, segundo indica, pelas "suffisances d'apparences" e o pedantismo. No entanto, a memória por ele visada nestas críticas é, sobretudo e em primeiro lugar, aquele gênero de memória empenhada na técnica de produção de discursos, posta a serviço da inventio retórica, à qual ela oferece um manancial (thesaurum) de argumentos e exemplos, dispostos em classificações e "lugares", as rubricas gerais que permitem encontrá-los, para sustentar a causa defendida em uma determinada peça oratória. Trata-se, portanto, aí, justamente da associação da memória àquela operação intelectual de identificação e nomeação de casos através de

\footnotetext{
32 Ibid., p. 1095. Ainda uma outra vez, neste mesmo ensaio, Montaigne utiliza-se desta fórmula ao relatar o efeito que tem sobre ele a crença de uma pessoa próxima, sobre os perigos do sereno da tarde: “... il m'a cuidé imprimer non tant son discours que son sentiment" (quase incutiu em mim não tanto seu discurso, mas seu sentimento) (ibid., p. 1084). Podemos lembrar ainda a passagem já mencionada em que o ensaísta afirma que conhecerá a lei geral do mundo quando a sentir: "En ceste université, je me laisse ignoramment et negligemment manier à la loy generale du monde. Je la sçauray assez quand je la sentiray." (ibid., p. 1073)
} 
noções gerais que, como já vimos, Montaigne censura nas artes, desde o início do ensaio. Ora, quando mobilizada pela experiência de si, a memória procede de modo bem diverso: não sustenta as operações de abstração e classificação de gêneros e espécies, mas associa e aproxima afecções e imagens ("sans regle, [...] et à tastons" (ibid., p. 1076), como nas associações imaginativas mobilizadas nos processos de memorização dos discursos) ${ }^{33}$, aprendidas de maneira plena, na sua imediatez sensível ou, enfim, na sua singularidade. Aqui, pela memória, revivemos nossos afetos, como que experimentamos novamente, de algum modo, o que sentimos no passado, evocamos sua presença viva.

É certo que tais associações se estabelecem mediante traços de semelhança ou por alguma afinidade entre as afecções repertoriadas pela observação e auto inspeção e, também, que estas semelhanças configuram um certo 'esquema' imaginativo que oferece à memória um suporte, um conjunto de balizas para suas operações ${ }^{34}$. No entanto, este 'quadro' com o qual opera a memória não se fixa ou cristaliza ao modo de uma grade de

${ }^{33}$ Referimo-nos aqui à Memória como uma das partes da arte retórica. Ela é posta em operação depois da articulação do discurso pela Invenção, Disposição e Elocução, como condição da boa Atuação do orador diante de seu público. Não se pode esquecer que esta parte da técnica ganha alguma autonomia no Renascimento com o aparecimento de suas numerosas Artes da Memória. Verificar, sobretudo, Yates, F. As Artes da Memória.

${ }^{34}$ Encontramos adiante uma observação valiosa sobre este gênero de procedimento: "A faute de memoire naturelle [diz ele] j'en forge de papier, et comme quelque nouveau symptome survient à mon mal, je l'escris. D'où il advient qu'à cette heure, estant quasi passé par toute sorte d'exemples, si quelque estonnement me menace, feuilletant ces petits brevets descousus comme des feuilles Sybillines, je ne faux plus de trouver où me consoler de quelque prognostique favorable en mon experience passée." (Ibid. p. 1092). 
conceitos; mantém-se móvel e instável, lábil e indeciso. Não identifica ou assimila as afecções atuais, apenas as aproxima das passadas, mantendo-as em sua inteira e concreta singularidade. E, de outro lado, como memória de afetos (não de conceitos), ela mesma atua como força afetiva sobre o espírito (pois também as lembranças emocionam), como uma força que potencializa ou atenua o afeto atual, aumenta ou diminui ("ralentiroit un peu leur impetuosité et leur course" - lbid. p. 1074) sua potência - enquanto a lembrança das afecções passadas e de seus efeitos é ela própria permeada pelas pulsões fundamentais (em intensidades e combinações diversas) da atração ou da repulsa, do amor e do ódio.

Enfim, a memória introduz na cena dos afetos e disposições presentes novos elementos afetivos, capazes de exacerbar ou de equilibrar os primeiros ou de "advertir" (afetivamente) o agente sobre seus efeitos possíveis: "Qui remet en sa mémoire l'excez de sa cholere passée, et jusques ou cette fièvre l'emporta, voit la laideur de cette passion mieux que dans Aristote, et en conçoit une haine plus juste." (ibid. p. 1073) A lembrança de afecções passadas semelhantes e de seus efeitos - odiosos ou desejáveis - traz imediatamente consigo (como que no nível da nossa animalidade) a repulsa ou a atração que contamina as afecções atuais. Por isso a metódica e constante observação de nossos movimentos internos, das paixões e disposições do espírito, "prepara para seus movimentos futuros": "Qui se souviens des maux qu'il a couru, de ceux qui l'ont menassé, des legeres occasions qui l'ont remué d'un estat à l'autre, se prepare par là aux mutations futures ..." (ibid.). Tudo observar e estudar, estender o campo da memória, acumular experiências, este é o estudo produtivo para se ‘aprender' o que evitar e o que seguir (“J'estudie tout: ce qu'il 
me faut fuyr, ce qu'il faut suivre" - Ibid. p. 1076). Ao invés, pois, de procurar a orientação incerta de um saber ordenado "[par] certains genres et chapitres", estabelecido por "divisions en classes et regions cogneues"(27), Montaigne indicará ao agente moral este caminho da inspeção de si mesmo e da acumulação, sempre flutuante, da memória -- como ele próprio o faz: “Je m"estudie plus qu'un autre sujet. C'est ma metaphysique, c'est ma physique" (ibid. p. 1072) - nesta inspeção de si mesmo, no registro das manifestações singulares de seu corpo e de seu espírito, estão toda sua física e sua metafísica.

Mas, se, como vemos, o ensaísta atribui a esta experiência um saldo positivo, se lhe reconhece, em alguma medida, a possibilidade de regular seus afetos, de ensinar-Ihe a enfrentá-los, é preciso observar que ela é sobretudo "pour l'interne santé exemplaire assez pour prendre l'instruction à contre-poil" (ibid., p. 1079 - grifo nosso). Pois, na verdade, visto que a experiência, sustentada pela memória, preserva a singularidade irredutível dos movimentos internos e disposições do sujeito, ela ensina, afinal, mais "par contrarieté" , "par disconvenance", que "par accord", "par difference" que "par similitude", como se lê na abertura do De l'Art de Conferer (Essais, III 8, p. 922). A experiência ensina mais a discriminar que a identificar; ela não só impede de generalizar, como possibilita distinguir (não confundir), e, assim, frear as ilusões do entendimento. $\mathrm{O}$ que mais seguidamente tiramos da experiência são advertências; ela nos oferece sobretudo contra-exemplos. Ensina mais a evitar que a seguir, atua, segundo a expressão daquele ensaio, mais "par fuite que para suite".

Mas, ainda, bem considerada esta experiência de si, podemos extrair 
dela, mostra-nos Montaigne, além das advertências para nossas condutas, um ensinamento ainda mais amplo e mais útil, uma advertência maior: a do reconhecimento de nossa condição de fragilidade - a imbecillitas da condição humana, isto é, sua inconstância, ignorância e tolice:

[...] C'est par mon experience que j'accuse humaine ignorance qui est, à mon avis, le plus seur party de l'eschole du monde. Ceux qui ne la veulent conclure en eux par um si vain exemple que le mien ou que le leur, qu'ils la recognoissent par Socrates, le maistre des maistres (ibid., p. 1075).

O preceito délfico do conhece-te a ti mesmo $^{35}$ encontra na fragilidade intelectual e moral dos homens seu sentido mais legítimo. Retomado por Sócrates, este preceito nos ensina nossa ignorância como uma condição intermediária entre saber e não saber ou, justamente, sua fragilidade e permanente insuficiência. Não se trata de anular nossa ciência ou de comprovar nossa inciência, mas de verificar sua fraqueza e obscuridades:

[...] Les difficultez et l'obscurité ne s'aperçoivent en chacune science que par ceux qui y ont entrée. Car encore faut il quelque degré d'intelligence à pouvoir remarquer qu'on ignore, et faut pousser à une porte pour sçavoir qu'elle nous est close (ibid.)

Não é dado aos homens renunciar à pretensão de saber, afastar seu

\footnotetext{
35 “L'avertissement à chacun de se cognoistre doibt estre d'un important effect, puisque ce Dieu de science et de lumieres le fit planter au front de son temple, comme comprenant tout ce qu'il avoit à nous conseiller" (ibid.).
} 
espírito da relação nativa que mantêm com a verdade. Montaigne não abre por acaso este ensaio com a sentença de Aristóteles (retomada a seu modo pelos estóicos): "Il n'est desir plus naturel que le desir de connoissance"36. Os homens querem saber e pretendem saber; precisam, entretanto, compreender ("remarquer") que este saber é frágil, inconstante e sempre provisório, permeado de não-saber, de ignorância, ou ainda, feito à medida de nossa condição. A marca do saber humano não é, enfim, a inciência ou a nulidade, mas sua "faiblesse". Esta fragilidade, ensinada pela experiência (sem a qual o ingênuo jamais aprenderá sua tolice ${ }^{37}$ ), traduz-se, no plano intelectual, por uma atitude examinadora -- uma "complexion studieuse" - e, no plano moral, pela moderação e a modéstia:

[...] Moy qui ne faicts autre profession [que a de seguir 0 preceito délfico], y trouve une profondeur et varieté si infinie, que mon apprentissage n'a autre fruict que de me faire sentir combien il me reste à apprendre. A ma foiblese si souvent recogneuë je doibts l'inclination que j'ay à la modestie, à l'obeyssance des creances qui me sont prescrites, à une

\footnotetext{
${ }^{36}$ A abertura da "Apologia de Raimond Sebond não pode aqui ser esquecida. Esse texto que se empenha em solapar os fundamentos da ciência, em mostrar a vanidade de sua pretensão de certeza, começa com a seguinte consideração: "C'est, à la verité, une tres utile et grande partie que la science, ceux qui la mesprisent, tesmoignent assez leur bestise; mais je n'estime pas pourtant sa valeur jusques à cette mesure extreme qu'aucuns luy attribuent ..."(Essais, II, 12, p.438).

37 "Cettuy-cy aura donné du nez à terre cent fois pour un jour: le voylà sur ses ergots, aussi resolu et entier que devant; vous diriez qu'on luy a infuz dépuis quelque nouvelle ame et vigueur d'entendement, et qu'il luy advient comme à cet ancien fils de la terre, qui reprenoit nouvelle fermeté et se renforçoit par sa cheute...” (ibid., p. 1075)
} 
constante froideur et moderation d'opinions... (ibid.).

A estas qualidades intelectuais e morais Montaigne oporá a arrogância, a afirmatividade (nunca dublada pela dúvida) e a "opiniastreté" - "signes exprez de bestise". Em matéria de auto conhecimento, "ce que chacun se voit si resolu et satisfaict, ce que chacun y pense estre suffisamment entendu, signifie que chacun n'y entend rien du tout, comme Socrates apprend à Euthydeme en Xenophon" 38 .

Montaigne termina estas considerações sobre a "experiência de si", sobre sua operação e seu interesse moral, com um excurso relativo à extensão dos benefícios desta experiência e de sua instrução também aos outros. Se o sujeito moral se observa, espia e tateia suas emoções e disposições ("je m'estudie plus qu'un autre sujet..."), adquirindo, assim, neste domínio, uma 'compleição investigadora' ("j’ay acquis une complexion studieuse en cela...”), torna-se também, por este prolongado exercício de auto-inspeção, certamente apto não só a reconhecer e distinguir, discriminar e julgar, os próprios movimentos internos, mas ainda os dos outros:

[...] Cette longue attention que j'employe à me considerer me dresse à juger aussi passablement des autres, et est peu de choses dequoy je parle plus heureusement et excusablement. II

\footnotetext{
${ }^{38}$ Lembremos aqui a célebre passagem do ensaio De la Presomption retomada tantas vezes depois: "On dit communement que le plus juste partage que nature nous aye fait de ses graces, c'est celuy du sens: car il n'est aucun qui ne se contente de ce qu'elle luy en a distribué [...] Je pense avoir les opinions bonnes et saines; mais qui n'en croit autant des siennes? L'une des meilleurs preuves que j'en aye, c'est le peu d'estime que je fait de moy [...] mes opinions je les trouve infiniement hardies et constantes à condamner mon insuffisance..."(Essais, II 17, p.657).
} 
m'advient souvent de voir et distinguer plus exactement les conditions de mes amys qu'ils ne font eux mesmes (ibid., p. 1076).

Mas (e a pergunta se impõe de imediato), como é possível penetrar as emoções e disposições internas de um outro? Montaigne, de forma sucinta, faz-nos compreender que esta comunicação se dá por espelhamento, por um procedimento que poderíamos, aproximadamente, assinalar como mimético: "Pour m'estre, dés mon enfance - diz --, dressé à mirer ma vie dans celle d'autruy [...] je laisse eschaper au tour de moy peu de choses qui y servent: contenances, humeurs, discours" (ibid., grifo nosso). Enxergar-se em um outro e espelhar o outro em si, restituindo à superfície externa das suas afecções alguma profundidade, decalcada nas próprias vivências, no conhecimento que se tem de si mesmo. O sujeito mobiliza, enfim, as próprias inclinações internas (observáveis) para decifrar os 'efeitos' ou manifestações ("productions") externas das afecções (invisíveis) dos outros. "Ainsin à mes amys je descouvre, par leurs productios, leurs inclinations internes", conclui o ensaísta. É certo que em vista da inacessibilidade da vida interior do outro, da singularidade dos agentes e da diversidade das ocorrências observadas e de suas circunstâncias, esta operação será sempre aproximativa e incerta ("passable" e "excusable"). Mas, em contrapartida, visto também que o espelhamento cumpre-se necessariamente no elemento da afinidade e da semelhança, ele se realizará de modo tanto mais feliz e bem sucedido quanto maiores forem entre os interlocutores os vínculos de convivência e amizade: "II m'advient souvent de voir et distinguer plus exactement les conditions de mes amys qu'ils ne font eux mesmes. J'en ay estonné quelq'un par la pertinence de 
ma description, et l'ay adverty de soy" (ibid.). É esta operação de observação e espelhamento -- certificada pelo assentimento e acolhimento da advertência por parte do amigo -- que constitui a dinâmica fundamental e o "ofício" mais valioso da amizade. ${ }^{39}$

Surpreendentemente, no entanto, um pouco mais adiante, o ensaísta parece estender este ofício da advertência, tão próprio -- e mesmo, de algum modo, exclusivo -- da amizade, justamente para o terreno que the parece 0 mais hostil, aquele das relações (por excelência assimétricas) entre senhor e súdito. Ora, se Montaigne sabe bem, como diz expressamente aí, que "la plus part des offices de la vray amitié sont envers le souverain en un rude et perilleus essay" (ibid., p. 1078), como, então, pretender atribuir este lugar do conselheiro do rei, desde sempre reservado ao adulador - "cette canaille de gens" (ibid.) -, a um súdito fiel, franco em suas palavras, "sans crainte de toucher vifvement et profondement le coeur du maistre" (ibid.) e de "luy pincer l'ouye" (ibid.) com suas verdades? Ora, passando para o registro político (deixando o espaço privado em que germinam as amizades), o dever da advertência, segundo mostra a passagem, ganha um outro estatuto e se estabelece a partir de premissas diversas. Quando Montaigne afirma 'j'eusse dict ses veritez à mon maistre, et eusse contrerrolé ses meurs, s'il eust voulu" (ibid., p. 1077), ele não entende, como amigo, advertir o soberano sobre suas 'condições' internas espelhadas e refletidas em si, mas pretende fazê-lo ver, como diz diretamente, "quel il est en l'opinion commune"; pois, aí está sua verdade -- a matéria à qual conformar sua ação -- e não nas suas próprias

\footnotetext{
${ }^{39}$ O ensaio I, 28, De l'Amitié, é o texto pelo qual melhor se compreende este processo de espelhamento e os ofícios da amizade.
} 
afecções e disposições. E vemos então que, neste domínio, a inspeção e investigação que respalda o juízo relativo "ao que é necessário fugir e ao que é necessário seguir" desloca-se da experiência de si para a experiência do "comum", do coletivo, a opinião pública -- a ser cuidadosamente escutada e auscultada e também ela associada (como ocorre no caso dos agentes privados) à memória, à memória histórica. São os humores, paixões e disposições da opinião pública as afecções sobre as quais, ou mesmo com as quais, atua o homem público e é sobre elas que o conselheiro fiel e verdadeiramente amigo deve the advertir. Trata-se de espelhar o sujeito político, público, nas afecções públicas. Montaigne expressa isto com toda a clareza:

[...] Or, il n'est aucune condition d'hommes qui ayt si grand besoing que ceux-la de vrays et libres advertissements. Ils soustiennent une vie publique, et ont à agreer à l'opinion de tant de spectateurs, que, comme on a accoustumé de leur taire tout ce qui les divertit de leur route, ils se trouvent, sans le sentir, engagez en la haine et detestation de leurs peuples pour des occasions souvent qu'ils eussent pue eviter, à nul interest de leurs plaisirs mesme, qui les eut advisez et redressez à temps. (ibid., p. 1078).

\section{A Medicina e a Natureza do Corpo}

Vimos, assim, como Montaigne prolonga sua crítica à pretensão normativa sobre as condutas humanas - dirigida, no primeiro grande movimento do ensaio, à arte jurídica --, voltando-a ao horizonte mais amplo da 
tradição das "artes de viver". No lugar do saber genérico e abstrato destas, como vimos, o ensaísta estabelece a experiência de si, única fonte de saber capaz de orientar nossas condutas, pois, enquanto apreensão sensível de vivências singulares, aumenta nossa capacidade de distinguir a especificidade das matérias sobre as quais nossas ações intervêm, permitindo-nos realizá-las de modo adequado. Agora, o ensaísta palmilhará o terreno da sua própria experiência relativa ao domínio do corpo, para ensaiá-la - realizá-la --, apropriar-se dela e apresentá-la ao leitor, opondo-a, a cada passo, à arte dos médicos, que oferece um discurso vazio e cego relativamente ao doente e à doença, prometendo a saúde e o alívio das dores, mas produzindo somente mais doença e sofrimento. A experiência de nós mesmos - mostrará Montaigne - é a única experiência possível da natureza que nos constitui na nossa singularidade: é a experiência da nossa compleição corporal (forjada pelos costumes), das afecções e doenças que em nós se manifestam (só adequadamente apreendidas por nossa própria experiência) e de nossa condição humana (cujos limites naturais devemos aprender, dirá ele, a "souffrir doucement" - ibid., p. 1089).

Montaigne abre este movimento oferecendo ao leitor, como útil para sua orientação, sua própria experiência no cuidado de sua saúde: "quant à la santé corporelle, personne ne peut fournir d'experience plus utile que moy..." (ibid., p. 1079). Pois, neste terreno, segundo pensa, nada pode ser mais útil do que o saber que a experiência nos proporciona. Os próprios médicos pretendem tê-la como pedra de toque e solo de sua prática ${ }^{40}$, embora, na verdade, façam seus

\footnotetext{
40 "Si faict la medecine profession d'avoir tousjours l'experience pour touche de son operation." (ibid.)
} 
diagnósticos e prescrevam seus tratamentos com base em representações abstratas de nossos corpos e de nossas doenças, e não de qualquer experiência efetiva: eles "nous guident comme celuy qui peint les mers, les escueils et les ports, estant assis sur sa table et y faict promener le modele d'un navire en toute seureté" (ibid.). Ao invés, pois, do discurso vazio da medicina, que se limita a identificar, nos casos, traços genéricos (essenciais) que assinalam uma determinada doença, Montaigne entende oferecer-nos sua experiência. E se diz que, neste domínio, ninguém pode apresentar experiência mais útil que ele, é porque teve uma longa convivência com a doença (“J'ay assez vescu, pour mettre en compte l'usage qui m'a conduict si loing..." - ibid., p. 1080), buscando observá-la, inspecioná-la, sem se deixar influenciar pelas categorias da medicina e pelas crenças comuns. Assim, apresenta suas vivências efetivas, vivas, "puras": "nullement corrompue par l'art et par l'opination"(ibid., p. 1079).

Somente aquele que tateia e sente seu corpo e suas enfermidades no que eles têm de mais próprios e de mais singulares ("em todos os seus acidentes e circunstâncias") é capaz, segundo o ensaísta, de julgar, de discriminar e avaliar, suas afecções, as patologias e as condições de sua saúde:

[...] Platon avoit raison de dire que pour estre vray medecin, il seroit necessaire que celuy qui l'entreprendroit eust passé par toutes les maladies qu'il veut guarir et par tous les accidens et circonstances dequoy il doit juger. C'est raison qu'ils prennent la verole s'ils la veulent sçavoir penser. (ibid.) 
A consideração, mesmo com seu traço de ironia, tem um alvo claro: aquele que não viveu uma doença, que não experimentou a trama das complexíssimas disfunções corporais que nela se exprimem, a identificará abstrata e aleatoriamente apenas por algum ou alguns de seus aspectos (alguns de seus inumeráveis acidentes e circunstâncias), interpretados por um modelo artificial de reconhecimento e de intervenção, incapaz de recobri-la na sua efetividade. Por isso, o médico que não viveu a doença mostra-se inepto para ajuizá-la, para julgá-la e oferecer-Ihe medicina adequada. O diagnóstico que Montaigne extrai de sua experiência sobre estas práticas é contundente:

[...] Les arts qui promettent de nous tenir le corps en santé et l'ame en santé, nous promettent beaucoup; mais aussi n'en est il poit que tiennent moins ce qu'elles promettent. Et en nostre temps, ceux qui font profession de ces arts entre nous en montrent moins les effects que tous autres hommes. On peut dire d'eus pour le plus, qu'ils vendent les drogues medicinales; mais qu'ils soyent medicins, cela ne peut on dire. (ibid.)

Enfim, se apenas a experiência pode nos orientar no cuidado com nossos corpos, é porque não apreende seus movimentos, afecções e disposições através de modelos, noções gerais ou conceitos, mas porque os apreende sensivelmente, inteiros e vivos. Mais do que um saber formal, Montaigne nos oferece, pois, sua experiência em relação ao corpo na forma de vivências ("essais de [sa] vie") registradas ${ }^{41}$ como "articles descousues" (sem ordem ou sistematicidade, como convém ao objeto fortuito de que trata), associados pelas operações da memória: "En voicy quelques articles, comme

\footnotetext{
41 "En fin, toute cette fricassée que je barbouille icy n'est qu'un registre des essais de ma vie..."
} 
la souvenance me les fournira" (ibid., p.1080). Oferece-nos as vivências de seu corpo, das doenças que the advêm e da condição mortal que toca a todos os homens e que ele experimenta de maneira concreta em si mesmo. Os ensinamentos desta experiência não têm valor de norma. Trata-se de uma experiência singular a ser produzida, ensaiada e degustada pelo autor, e remetida ao seu leitor, que encontra nela um quadro (heurístico, poderíamos dizer) que, por semelhanças, Ihe permite evocar e contrastar suas próprias vivências e que Ihe oferece apenas a medicina - a única eficaz - da advertência.

Começa aqui, propriamente, o ensaio de sua experiência, ou ao menos uma amostragem dela: "Pour qui en voudra gouster, j'en ay faict l'essay, son eschançon." (ibid.) Na primeira de suas considerações, o ensaísta revela que não adota uma conduta fixa em relação aos cuidados do corpo, mas que a varia "selon les accidents", visto que o corpo e tudo aquilo que a ele se relaciona está sujeito à mudança e à variação. Propõe-se, no entanto, a apresentar as maneiras de agir que mais freqüentemente põe em prática: "celles que j'ay plus souvent veu en train, qui ont eu plus de possession en moy jusqu'à cette heure". (ibid.) E é neste ponto que, de fato, se inicia o terceiro movimento do ensaio, com a apresentação do primeiro dos ensinamentos que se estenderão até o final do texto.

Em sua primeira observação, Montaigne diz que, doente, adota exatamente os mesmos hábitos que segue quando saudável, sem variá-los qualitativamente, mas apenas quantitativamente - moderando-os aqui e ali:

[...] Ma forme de vie est pareille en maladie comme en santé: mesme lict, mesmes heures, mesmes viandes me servent, et mesme breuvage. Je n'y adjouste du tout rien, que la 
moderation du plus et du moins, selon ma force et appetit. (ibid.)

Ao se examinar, ele verifica, portanto, que sua saúde - o bom funcionamento de seu corpo - está referida a certas regularidades, ou ainda consiste no seu funcionamento justamente regular, em manter-se na sua trilha. $E$ assinala ainda que estas regularidades não se estabelecem segundo regras ou leis da natureza, mas são produzidas pelo costume:

[...] Ma santé, c'est maintenir sans destourbier mon estat accoustumé. Je voy que la maladie m'en desloge d'un costé? si je crois les medecins, ils m'en destourneront de l'autre: et par fortune et par art, me voylà hors de ma route. (ibid.)

Deste modo - podemos constatar -, Montaigne inicia a exposição do aprendizado que tira da observação de seu corpo contrastando-o com a concepção naturalista da medicina, com suas concepções de doença e saúde e, ainda, com a prática da dietética, que, justamente, prescreve mudanças de hábitos como caminho para a cura das patologias. Para a medicina, o estado natural de saúde do corpo é abalado (e aqui ressaltamos que Montaigne não se ocupa das doenças congênitas ${ }^{42}$ ) por fatores contrários à constituição física

\footnotetext{
${ }^{42}$ Doenças necessárias (por ananké), provocadas pela própria phýsis do indivíduo, em que há um desequilíbrio humoral constitutivo. O corpo humano, na medicina hipocrática, é constituído pela mistura (krásis) de quatro 'sucos' ou humores (khymós) - sangue, fleuma, bílis amarela e bílis negra - que se dispõem em quatro combinações, cada uma com a prevalência de um deles, as quais formam quatro temperamentos ou disposições físico-psíquicas básicas respectivamente, sangüínea, fleumática, colérica e melancólica. Toda patologia, para a
} 
natural do indivíduo, sejam fatores casuais e independentes de sua vontade, sejam comportamentos que ele adote. Seguindo hábitos contrários à natureza de seu corpo, o indivíduo adoece. Para que recupere sua saúde, o médico lhe recomenda o abandono dessas condutas e a adoção daquelas que, por natureza, são conformes à sua compleição corporal. A medicina adota, portanto, em suas concepções de saúde e de doença, uma visão naturalista do corpo, segundo a qual este é por natureza inclinado a tal ou tal modo de vida.

A experiência do próprio corpo ensina a Montaigne, no entanto, que são os hábitos que ele adota desde sua mais tenra infância que forjam sua compleição corporal:

[...] C'est à la coustume de donner forme à nostre vie, telle qu'il lui plaist; elle peut tout en cela: c'est le breuvage de Circé, qui diversifie nostre nature comme bon luy semble. (ibid.)

Nesse sentido, não é possível dizer que existem hábitos por natureza favoráveis ou desfavoráveis à sua compleição física, apenas que existem comportamentos favoráveis ou desfavoráveis enquanto mais próximos ou afastados daqueles que ele adotou e incorporou - e que, por instaurarem regularidades em seu corpo, constituem seu estado de saúde, o equilíbrio da normalidade. A doença, dessa forma, é fruto de qualquer fator que venha a comprometer a regularidade instaurada pelo hábito - seja um fator casual e independente de sua vontade, seja um comportamento que ele adote e que contrarie os costumes de seu corpo. E ele adoece - como veremos mais à frente - se não teve o cuidado de variar seus hábitos de vez em vez, mas se os 
deixou se cristalizar, de forma a não poder suportar nenhum tipo de mudança em seu modo de vida. De outra forma, avalia Montaigne, a doença virá 'par fortune', por acaso, já que ele, variando aqui e ali seus modos de vida, mantém o horizonte de sua saúde, não importando as vicissitudes e situações adversas em que se encontra.

A observação sobre o poder de conformação dos costumes, no entanto, como pudemos observar na passagem supracitada, não se refere apenas aos comportamentos e aos corpos, mas tem um alcance muito mais amplo. Diz respeito ainda ao caráter dos povos, aos diferentes usos nacionais ou regionais, aos costumes familiares e à singularidade dos indivíduos. O costume conforma todos os modos de vida.

Boa parte da seqüência do texto será destinada ao arrolamento de exemplos que corroborem a tese da formação - e diversificação - das compleições corporais, espirituais e culturais dos homens e suas cidades pelos costumes. Instaurados, seguidos e repetidos ao longo do tempo, os costumes forjam diferentes modos de ver e de ser; produzem profundas variações nos comportamentos dos homens, em seus modos de conceber o mundo, os outros, a eles mesmos, ou ainda de se relacionar com o meio que os cerca e com os demais homens. Montaigne prossegue arrolando uma série de casos que mostram as diferentes relações dos povos com o clima (seus modos de se aquecer, de enfrentar o sereno), seus hábitos diversos relativos à alimentação, à bebida, ao sono etc.:

[...] Combien de nations, et à trois pas de nous, estiment ridicule la crainte du serain, qui nous blesse si apparemment; et 
nos bateliers et nos paysans s'en moquent. Vous faites malade un Aleman de le coucher sur un matelas, comme un Italien sur la plume, et un François sans rideau et sans feu. L'estomac d'un Espagnol ne dure pas à nostre forme de manger, ny le nostre à boire à la Souysse. (ibid.)

Mostra-nos mesmo que as profundas diferenças nos modos de ver e de ser dos homens sequer se associam à distância do tempo e do espaço em que vivem. Pessoas que habitam os mesmos lugares, na mesma época, podem apresentar, em função de inumeráveis determinações de nascimento, circunstâncias, educação ou hábitos, disposições físico-psíquicas e modos de vida absolutamente distintos. Mesmo nos sendo próximos, podem revelar-se mais diversos de nós que os integrantes dos povos mais afastados no espaço ou no tempo: "Regardez la difference du vivre de mes valets à bras à la mienne: les Scythes et les Indes n'ont rien plus esloigné de ma force et de ma forme." (ibid., p. 1082)

Vale a pena observar que Montaigne vai arrolando casos e exemplos de variações referentes aos costumes até se deter em um caso especial: aquele dos homens que só acreditam nos escritos, sobretudo os do passado: "Que ferons nous à ce peuple qui ne fait recepte que de tesmoignages imprimez, qui ne croit les hommes s'ils ne sont en livre, ny la verité si elle n'est d'aage competant?" (ibid., p. 1081). Por um lado, esta observação visa, certamente, apenas a assinalar mais uma variação dos costumes (uma astuta 'relativização' da cultura de seu tempo, cujo traço mais saliente é apresentado como mais uma variação antropológica, de valor idêntico ao das demais já arroladas); mas, por outro lado, trata-se também de atribuir a este caso uma função 
reflexiva bem nítida: trazendo como exemplo da singularidade dos costumes justamente a cultura da exemplaridade moral (associada às Letras clássicas), Montaigne atesta, com a própria afirmação da singularidade de sua forma (o valer-se apenas de exemplos alheios, tomados do passado pela mediação do escrito), a exigência de que cada um consulte o presente da própria experiência, na sua forma viva, não escrita. "Je dis souvent que c'est pure sottise qui nous fait courir apres les exemples estrangers et scholastiques. Leur fertilité est pareille à cette heure à celle du temps d'Homere et de Platon." (ibid.) Ele se opõe, portanto, à tola atribuição de autoridade ao escrito, enquanto escrito, em detrimento do dito e ao antigo, enquanto antigo, em detrimento do novo, e equipara o testemunho - a experiência - dos clássicos àquele que sua própria experiência Ihe fornece:

[...] Mais moy, qui ne mescrois non plus la bouche que la main des hommes, et qui sçay qu'on escript autant indiscretement qu'on parle, et qui estime ce siecle comme un autre passé, j'allegue aussi volontiers un mien amy que Aulugele et que Macrobe, et ce que j'ay veu que ce qu'ils ont escrit. (ibid.)

Daí em diante, o texto arrolará, em pé de igualdade, os exemplos clássicos ao lado daqueles que ele mesmo e seu tempo testemunharam, como se vê nesta passagem:

[...] Or sur mon subject, laissant les exemples que je sçay par les livres et ce que dict Aristote d'Andron, Argien, qu'il traversoit sans boire les arides sablons de la Lybie, un gentil-homme, qui s'est acquité dignement de plusieurs charges, disoit où j'estois qu'il estoit allé de Madril à Lisbonne en esté sans boire. (ibid.) 
Uma longa sequência de exemplos permite, então, ao ensaísta sublinhar sua convicção sobre a origem costumeira das regularidades que moldam nossos corpos e, justamente, regulam seu funcionamento, e reforçar a tese de que o caminho para nossa saúde (o funcionamento regular do corpo, é preciso insistir) se encontra na manutenção de nossos hábitos. No entanto, a mesma experiência de seu corpo o levará também a reconhecer que, certamente, o melhor de seus hábitos corporais é aquele de ser "flexible et peu opiniastre" (ibid., p. 1083), ou seja, o de ser capaz, com facilidade, de afastar-se deles ocasionalmente, se os acontecimentos e circunstâncias assim o exigirem. Montaigne diz ter assumido, junto com os hábitos e regularidades encarregados de "dar forma à [sua] vida" --, uma certa aptidão para a mudança e a variação, quando as ocasiões o requerem. Esta experiência das vantagens da maleabilidade leva-o, assim, a advertir o jovem sobre os males da fixação em nossos hábitos, do enrijecimento de nossa compleição corporal; enfim, sobre os benefícios do habituar-se a certa flexibilidade. Dada a natureza costumeira das regularidades de nosso corpo (e das inclinações que produzem), tendo em vista não advirem de nenhuma necessidade natural, o jovem, para permanecer maleável, para manter seus hábitos "ploiable[s] et soupple[s]" (ibid.), deverá, diz o ensaísta, contrariá-los ocasionalmente e lançar-se muitas vezes no próprio excesso e desmedida ("autrement la moindre debauche le ruyne"43). "Un jeune homme doit troubler ses regles pour esveiller sa vigueur, la garder de moisir et s'apoltronir" (ibid.). Ele se torna, assim, vigoroso, capaz de suportar, sem embaraços e sofrimento, diversidades e

\footnotetext{
${ }^{43}$ Ibid. A mesma idéia é desenvolvida no ensaio I, 26, De l'institution des enfants, p. 167: "Je veux qu'en la debauche mesme il surpasse en vigueur et en fermeté ses compagnons."
} 
adversidades (climas diversos, outros hábitos alimentares, outras condições de vida), além de tornar-se sociável e agradável no convívio com os homens mais diversos.

A esta virtude do jovem vigoroso e sociável Montaigne opõe aqui (e ele volta a esse tema outras vezes nos Ensaios) o vício da "delicatesse". Se permitir que seus hábitos corporais se fixem e se enrijeçam, se permitir que sua saúde se empenhe em regularidades sistemáticas e estáveis, o jovem se tornará 'delicado' e sensível, incapaz de acompanhar seus colegas, inapto para o convívio:

[...] II y a de la honte de laisser à faire par impuissance ou de n'oser ce qu'on voit faire à ses compaignons. Que telles gens gardent leur cuisine. Par tout ailleurs il est indecent, mais à un.homme de guerre [um nobre] il est vicieux et insuportable, lequel, comme disoit Philopoemen, se doit accoustumer à toute diversité et inegalité de vie. ${ }^{44}$

Não se permitam os jovens, considera o ensaísta, tornarem-se escravos de seus hábitos - "il n'est train de vie si sot et si debile que celuy que se conduit par ordonnance et discipline" --, pois a rigidez leva à 'delicatesse' (que a vida penaliza) e às idiossincrasias (que dificultam a relação com os homens):

[...] il se rend incommode et desaggreable en conversation. La plus contraire qualité à un honneste homme, c'est la delicatesse et obligation à certaine façon particulière; et elle est particuliere si elle n'est ploiable et soupple. (ibid.)

\footnotetext{
${ }^{44}$ Ibid. Ainda referindo-nos ao paralelismo com o ensaio I 26, cf. p. 166: "Qu'on rend hardiment un jeune homme..."
} 
Estas advertências conduzem o ensaísta à conclusão mais ampla extraída de sua experiência relativa ao corpo. E ele a formula de maneira lapidar: "On se doit adonner aux meilleures regles, mais non pas s'y asservir" (ibid., p. 1085), apegar-nos às regularidades mais benéficas, mas não nos escravizarmos a elas, para acostumarmos nosso corpo a manter sua saúde mesmo em situações adversas às suas inclinações mais próprias e espontâneas, suas inclinações naturais. Por esta dupla recomendação referente aos cuidados do corpo, somos, enfim, exortados a manter nossos costumes ("[les] inclinations plus propres et ordinaires et plus agreables" - ibid., p. 1083), responsáveis por nossa saúde, mantendo embora o domínio sobre estas regularidades, não permitindo que se transformem em necessidade, que nos domine como uma necessidade natural. "Estendons nostre possession jusque aux derniers moyens" (ibid., p. 1084), exorta Montaigne. Não estamos escravizados e submetidos a necessidades (naturais) do nosso corpo, ele se oferece a nós como um espaço para o exercício de nossa autonomia.

Montaigne não deixa aqui, como sempre, de fustigar seu leitor com imagens fortes. llustra, quase como emblema, estas considerações sobre 0 exercício corporal da autonomia com um exemplo que alcança a todos: a evacuação, "[les] plus sales services". Trata-se da função quase paradigmática da necessidade (como atestam freqüentemente as expressões que a designam) e ainda do conforto das regularidades nas coisas do corpo, mas também daquela que mais experimenta, mesmo na vida cotidiana, embaraços e limitações. Ora, adverte o ensaísta, se é benéfico submeter este ato a uma regularidade costumeira, não devemos, no entanto, escravizar-nos a ela e, 
sobretudo, a certas comodidades particulares; é preciso, ao menos ser ploiable às imposições das circunstâncias de lugar, de comodidades e mesmo de sua duração possível.:

[...] Et les Roys et les philosophes fientent, et les dames aussi.

[...] je diray cecy de cette action: qu'il est besoing de la renvoyer à certaines heures prescriptes et nocturnes, et s'y forcer par coustume et assubjectir, comme j'ay faict; mais non s'assujectir, comme j'ay faict en vieillissant, au soing de particuliere commodité de lieu et de siege pour ce service, et le rendre empeschant par longueur et mollesse. (ibid., p. 1085)

Duas outras experiências, no entanto, levam Montaigne a limitar 0 universo dos destinatários das advertências sobre a autonomia relativa ao próprio corpo: as experiências da velhice e da doença. Com o peso dos anos, o ensaísta vê a estabilização de seus hábitos e sua manutenção quase como necessárias - indispensáveis - para a saúde de seu corpo:

[...] m'estant en vieillissant plus arresté sur certaines formes [...], la coustume a desjà, sans y penser, imprimé si bien en moy son caractere en certaines choses, que [...] sans m'essaier, ne puis ny dormir sur jour, ny faire collation entre les repas, ny desjeuner, ny m'aller coucher sans grand intervalle, comme de trois bonnes heures, apres le soupper [...] (ibid., p. 1083) 
A fragilidade trazida pelo tempo, ele observa, impede a luta contra o processo de enrijecimento dos hábitos, tornando-o quase inexorável. Assim, a formação de novos hábitos corporais, ou mesmo a flexibilidade em relação aos antigos, não podem ser exigidos do homem de idade, que está fora do alcance da educação: "mon aage est hors d'institution et n'a desormais dequoy regarder ailleurs que à se maintenir" (ibid.). Resta-lhe apenas, como condição da saúde, seguir os seus hábitos, já transformados em 'mollesses', em 'delicatesses' (“Je dois plusieurs telles mollesses à l'usage" - ibid., p. 1084) ${ }^{45}$.

Ora, além do homem de idade, Montaigne verifica que também a doença acomoda-se melhor à regularidade dos costumes. Se, sem dúvida, a mudança de hábitos, levando à perda dos equilíbrios fisiológicos, faz mal a qualquer um - "Le changement, quel qu'il soit, estonne et blesse" (ibid., p. 1085) --, ela prejudica, ainda mais, o doente, já debilitado pela patologia. Para este, diz Montaigne, não há conduta mais segura do que manter-se em seus próprios hábitos: "Je ne juge donc point, comme je disois, où les malades se puissent mettre mieux en seurté qu'en se tenant quoy dans le train de vie où ils se sont eslevez et nourris." (ibid.) Manter suas regularidades costumeiras, o horizonte da saúde, certamente o ajudará a enfrentar os percalços da doença em melhores condições.

E, no entanto, os médicos, operando com sua falsa compreensão do corpo (pois o vêem como caso de um gênero natural e ignoram sua constituição 'costumeira'), tomando os hábitos do paciente como causas de sua doença, pretendem afastá-los deles: "On leur va ordonnant, une non seulement

\footnotetext{
45 Sendo que Montaigne acrescenta às 'mollesses' adquiridas com o hábitos algumas que possui 'por natureza': "Nature m'a aussi, d'autre part, apporté les siennes". (ibid.)
} 
nouvelle, mais contraire forme de vie: mutation qu'un sain ne pourroit souffrir." (ibid.) Ora, desviando o doente daquilo a que o inclinam seus hábitos, o médico não só o afasta do que lhe dá conforto e prazer ${ }^{46}$, mas também do que lhe é mais próprio e apropriado (o que é mais seu), do que dá forma a sua vida: "Cogimur a suetis animum suspendere rebus, Atque, ut vivamus, vivere desinimus (obrigam-nos a renunciar a nossos hábitos e cessamos de viver para viver)." As Assim, constata a contradição a que a medicina se expõe por sua concepção naturalista de corpo: em vez de fazer bem, faz mal, preparando os pacientes, pouco a pouco, não para a vida - sua vida - mas para a morte: "S'ils ne font autre bien, ils font au-moins cecy, qu'ils preparent de bonne heure les patiens à la mort, leur sapant peu à peu et retranchant l'usage de la vie." (ibid.)

A experiência ensina, pois, a Montaigne que, velho e doente, deve manter seus hábitos e continuar usufruindo de seus prazeres, que não podem Ihe fazer mal - "rien ne me nuit que je face avec faim et allegresse; je n'ay jamais nuisance d'action qui m'eust esté bien plaisante" (ibid., p. 1086) -, visto que são o que seu corpo busca mais espontaneamente, aquilo a que se

\footnotetext{
${ }^{46}$ Montaigne se refere, certamente, a conforto e prazer duráveis, persistentes (pois associados a hábitos), não incluindo aí os prazeres desmedidos, imoderados, do intemperante, que ele apresentará, mais adiante, segundo se verá, como uma doença do prazer.

${ }^{47}$ Citação de Maximianus, ibid., p.1085, precedida do seguinte comentário: "Allez croire que les chastaignes nuisent à um Perigourdin ou à um Lucquois, et le laict et le fromage aux gens de la monaigne. On leur va ordonnant, une non seulement nouvelle, mais contraire forme de vie: mutation qu'um sain ne pourroit soufrir. Ordonnez de l'eau à un Breton de soixante dix ans, enfermez dans une estuve un homme de marine, deffendez le promener à un laquay basque; ils les privent de mouvement, et en fin d'air et de lumiere."
} 
habituou ao longo do tempo ${ }^{48}$. E ela ensina também que tudo o que the causa dor só pode prejudicá-lo - "quoy que je reçoive desagreablement me nuit" (ibid.) -, pois, se the causa desconforto e desagrado é porque se revela estranho e inapropriado à sua constituição física. Portanto, sobretudo os velhos, quando doentes, não devem deixar de satisfazer suas inclinações e desejos, associados a modos de vida enraizados e como que atestados pela própria duração de suas vidas - "et sain et malade, je me suis volontiers laissé aller aux appetits qui me pressoient" (ibid.) -, nem aceitar os tratamentos desagradáveis que os médicos lhes impõem: "Je n'ayme point à guarir le mal par le mal; je hay les remedes qui importunent plus que la maladie." (ibid.)

A experiência ensina, enfim, que o velho deve manter seus hábitos, a despeito de toda prescrição médica, porquanto esta conduta mantém o terreno e o horizonte da saúde, a vida regular, normal, do corpo, mesmo perturbada por circunstâncias e acidentes. Já o médico lhe promete alcançar, pelo mal temporário do tratamento, a saúde, apresentando-a apenas como um bem futuro. Montaigne mostra, no entanto, que nem mesmo isto ele the pode garantir; pois, a doença que o afeta vem e vai "par fortune". Se seus hábitos são saudáveis, moderados e puderam inscrever-se e manter-se em sua vida

\footnotetext{
${ }^{48} \mathrm{~A}$ identidade entre o que agrada e o que faz bem - entre o prazer e o bem do corpo - só pode ser compreendida à luz da constituição "costumeira" do corpo e de suas regularidades. Aquilo que visamos por nossos apetites e, portanto, é-nos agradável, é aquilo a que estamos habituados e que, assim, é apropriado às disposições do nosso corpo, faz-nos bem. Esta questão será diretamente considerada por Montaigne nos momentos finais do ensaio, mas remete também às considerações de Aristóteles sobre o caráter não apenas intelectual, mas ainda desiderativo das virtudes morais (que supõem que o hábito refira os apetites aos fins adequados e encontre neles seu prazer, como já indicamos em nossa introdução).
} 
por longo tempo, não há porque atribuir a eles os males do corpo, envolvidos pela doença. Vale mais, assim, considera Montaigne, manter suas formas de vida; pois, com isso, garante um bem, e ainda seus prazeres: "Puisque on est au hazard de se mesconter, hazardons nous plustost à la suitte du plaisir." (ibid.) Ao contrário, aceitando as prescrições médicas, ele se vê afetado por dois males - pela mudança penosa de seus hábitos de vida e pela doença, que aquelas mudanças, as novas regras prescritas pelo médico, por si mesmas, não curam: "D'estre subject à la cholique et subject à m'abstenir du plaisir de manger des huitres, ce sont deux maux pour un. Le mal nous pinse d'un costé, la regle de l'autre." (ibid.)

Montaigne, porém, não se limita a este argumento da casualidade e acidentalidade da doença para sustentar sua decisão de manter diante dela os próprios hábitos e satisfazer seus desejos. Invoca, não sem alguma ironia, a possibilidade de sempre corroborar tal decisão com o aval da autoridade dos próprios médicos. Pois, dada a diaphonia existente no campo da medicina, as controvérsias de opinião entre seus praticantes, sempre se encontrará, diz ele, algum deles que autorize com seu saber a manutenção dos nossos hábitos e a satisfação de nossos apetites:

[...] L'art de medecine n'est pas si resolue que nous soyons sans authorité, quoy que nous facions: elle change selon les climats et selon les Lunes, selon Farnel et selon l'Escale. Si vostre medecin ne trouve bon que vous dormez, que vous usez de vin ou de telle viande, ne vous chaille: je vous en trouveray un autre qui ne sera pas de son advis. La diversité des arguments et opinions medicinales embrasse toute sorte de formes. (ibid., p. 1087) 
É certo que ao defender, para as situações de doença, a manutenção dos hábitos estabelecidos e a recusa das prescrições da dietética, Montaigne não sugere que deixemos de tratar as doenças que nos acometem, recomenda apenas que não o façamos nos termos da medicina. Pois, a experiência ${ }^{49}$ ainda the ensina que as doenças são processos que têm seu desenvolvimento, declínio e fim próprios:

[...] Les maux ont leur vie et leurs bornes, leurs maladies et leur santé. La constitution des maladies est formée au patron de la constitution des animaux. Elles ont leur fortune limitée dés leur naissance, et leurs jours. (ibid., p. 1088)

Afrontar estes processos, tentar abreviá-los, interferir em seu curso espontâneo, como fazem os médicos, aguilhoa a doença e a faz reagir e mesmo se expandir: "qui essaye de les abbreger imperieusement par force, au travers de leur course, il les allonge et multiplie, et les harselle au lieu de les appaiser". (ibid.) Portanto, vale mais deixá-las prosseguir espontaneamente, pois assim duram menos e nos atingem de maneira mais suave:

[...] On doit donner passage aux maladies; et je trouve qu'elles arrestent moins chez moy, qui les laisse faire; et en ay perdu, de celles qu'on estime plus opiniastres et tenaces, de leur propre decadence, sans ayde et sans art, et contre ses reigles. (ibid.)

\footnotetext{
${ }^{49}$ O caráter de relato da própria experiência deste texto é expresso: "J'ay laissé envieillir et mourir en moy de mort naturelle des reumes, defluxions gouteuses, relaxation, battement de
} 
Isto, evidentemente, não significa, segundo indica, que devamos "leur succomber de mollesse"; apenas assinala que não devemos opor-nos a elas "obstinéement $(\ldots)$ et à l'estourdi”, e sim "leur (...) ceder naturellement, selon leur condition et la nostre" (ibid.): dar-lhes espaço para que nos ataquem e responder a cada uma de suas investidas, na exata proporção em que nos atingem, "comme entre ceux qui jouent à la paume, celuy qui soustient se desmarche et s'apreste selon qu'il voit remuer celuy qui luy jette le coup et selon la forme du coup." (ibid.) Enfrentá-las, pois, golpe a golpe, pontual e atentamente, segundo suas manifestações, sem pretender dominá-las e vencêlas, como se conhecêssemos de antemão sua natureza e seus movimentos.

Uma objeção que poderia ser feita a esta conduta - e a favor da intervenção impaciente, totalizante e violenta da medicina - diz respeito ao risco de morte empenhado em certas doenças: “-- Mais un tel en mourut!", dirão frequentemente. Ora, este risco não justifica, segundo o ensaísta, que nos submetamos aos tratamentos médicos, visto que com eles a possibilidade de morte permanece igualmente presente - o que comprova 0 caráter inteiramente acidental, fortuito e singular das doenças - "Et combien n'ont pas laissé d'en mourir, ayant trois medecins à leur cul?", responde ele. Além do mais, a morte não é uma mera possibilidade; é um acontecimento inevitável, um fato inexorável de nossa vida - "Si fairés vous, sinon de ce mal là, d'un autre" -, que devemos aprender a padecer suavemente: "Il faut souffrir doucement les loix de nostre condition. Nous sommes pour vieillir, pour affoiblir,

coeur, micraines et autres accidens, que j'ay perdu quand je m'estois à demy formé à les nourrir. On les conjure mieux par courtoisie que par braverie." (ibid., p. 1089) 
pour estre malades, en despit de toute medecine." (ibid., p. 1089) A velhice, a doença e a morte - mostra Montaigne -- são leis da condição humana, fatos ou acontecimentos que atingem necessaria e universalmente a vida dos homens.

Porém, o que entender exatamente por condição humana? Já vimos que o autor nos diz claramente que os homens são formados por seus costumes, que forjam suas maneiras de ser, seus modos de ver o mundo e mesmo suas diversas disposições físico-psíquicas. Num certo nível, portanto, a condição do homem é a de produzir-se por seus costumes - os quais, pela sua diversidade, fazem-no aparecer como um ser "incerto, variável e irresoluto" (Essais, I, 1, p.). No entanto, é verdade também que todos os homens necessariamente envelhecem, adoecem e morrem, ou seja, todos apresentam determinações que, tomadas absolutamente, escapam do "poder dos costumes" (Essais, I, 23, p.). Há, assim, uma condição mortal universal dos homens: o poder transformador e diversificador dos costumes se exerce dentro de limites impostos pela natureza. A condição humana designa, pois, este "ingenieux meslange" ${ }^{50}$ de cultura e natureza, uma natureza que se vê ininterruptamente transformada pelos costumes, que se lhe sobrepõem, dando-lhe em cada caso "un different visage". Não alcançamos a natureza pura, aquém dos costumes, a "loy generale du monde" (Essais, De l'Experience, p. 1073) . Por isso, diz Montaigne, "Je la sçauray assez quand je la sentiray" (Ibid.). E ele a alcança mais diretamente na experiência da morte que na da vida, sempre já permeada

\footnotetext{
50 Para utilizar a expressão já utilizada pelo autor em outro contexto, que analisamos anteriormente: "Comme nul evenement et nulle forme ressemble entierement à une autre, aussi ne differe nulle de l'autre entierement. Ingenieux meslange de nature. Si nos faces n'estoient semblables, on ne sçauroit discerner l'homme de la beste; si elles n'estoient dissemblables, on ne sçauroit discerner l'homme de l'homme." Essais, De l'Experience, p. 1070.
} 
- informada - pelos costumes. É no declínio de sua saúde e na decadência de seu corpo, isto é, na velhice, na doença e na iminência da morte, que o ensaísta sente, apreende esta natureza; que conhece, por experiência, as leis da humana condição.

Ora, se o envelhecimento, o adoecimento e a morte são eventos necessários e universais, ninguém pode lamentar por ter sido acometido ou ameaçado por eles, como se fosse vítima de alguma injustiça, nem pode pretender evitá-los. Lastimá-los como injustos, é ser injusto - afinal aplicam-se a todos de maneira igual: "C'est injustice de se douloir qu'il soit advenu à quelqu'un ce qui peut advenir à chacun, indignare si quid in te inique proprie constitutum est..51 (ibid. p. 1089) Pretender afastá-los, por sua vez, é sinal de loucura: "Voyez un vieillart, qui demande à Dieu qu'il luy maintienne sa santé entiere et vigoreuse, c'est à dire qu'il le remette en jeunesse. Stulte, quid haec frustra votis puerilibus optas? N'est-ce pas folie? Sa condition ne le porte pas." (ibid.) Desse modo, devemos aprender a "souffrir doucement les loix de nostre condition" (ibid.) - o que não equivale a uma triste resignação. Ao contrário, 'padecer suavemente' o medo da morte, assim como as dores físicas e psíquicas em geral, consiste - mostrará Montaigne mais à frente - em saber vivê-las sem Ihes dar importância ou prestar-Ihes atenção, mas reduzindo-as em sua duração e significado por meio do desvio da própria consciência que, voltada para outros objetos ou realidades agradáveis - em uma palavra: distraída - deixa toda dor 'escoar', passar de maneira fugidia, efêmera, afetando-nos de maneira menos sensível:

[...] je passe le temps, quand il est mauvais et incommode;

\footnotetext{
51 “Lamenta-te se apenas a ti impõe-se-te uma lei injusta” (Sêneca, Epístolas a Lucílio, XCl)
} 
quand il est bon, je ne le veux pas passer, je le retaste, je m'y tiens. II faut courir le mauvais et se rassoir au bon. [...] (Ibid. p., 1111)

[...] Voicy depuis, de nouveau, que les plus legers mouvements espreignent le pur sang de mes reins. Quoy, pour cela je ne laisse de me mouvoir comme devant et picquer apres mes chiens d'une juvenile ardeur, et insolente. [...] sens je quelque chose qui crosle? Ne vous attendez pas que j'aille m'amusant à recognoistre mon pous et mes urines pour y prendre quelque prevoyance ennuyeuse; je seray assez à temps à sentir le mal, sans l'alonger par le mal de la peur. Qui craint de souffrir, il souffre desjà de ce qu'il craint. [...] Regardez ceux qui font autrement et qui dependent de tant de diverses persuasions et conseils: combien souvent l'imagination les presse sans le corps' [...] (lbid., p. 1095)

O mesmo mecanismo - que, no plano dos discursos, tem na amplificatio retórica seu equivalente - Montaigne propõe para a relação com o prazer. Isto é, que o sujeito amplie o prazer que experimenta em sua duração e significado, aplicando-Ihe vivamente não só os sentidos, mas a consciência, fruindo-o passo a passo, lentamente, alcançando-o em toda sua profundidade e extensão, detendo-o ou ao menos o retardando no tempo - tornando seu efeito e sentido mais vivo, pleno:

[...] Les autres sentent la douceur d'un contentement et de la prosperité; je la sens ainsi qu'eux, mais ce n'est pas en passant et glissant. Si la faut il estudier, savourer et ruminer, pour en 
rendre graces condignes à celuy qui nous l'ottroye. Ils jouyssent les autres plaisirs comme ils font celluy du sommeil, sans les cognoistre. A celle fin que le dormir mesme ne m'eschapat ainsi stupidement, j'ay autresfois trouvé bon qu'on me le troublat pour que je l'entrevisse. Je consulte d'un contentement avec moy, je ne l'escume pas; je le sonde et plie ma raison à le recueillir, devenue chagreigne et desgoutée. Me trouve-je en quelque assiete tranquille? y a il quelque volupté qui me chatouille? je ne la laisse pas friponer aux sens, j'y associe mon ame, non pas pour s'y engager, mais pour s'y agreer, non pas pour s'y perdre, mais pour s'y trouver [...] (Ibid., p. 1112)

É desse controle sobre os estados de prazer e de dor (não somente físicos, mas ainda psíquicos), controle sempre difícil e que precisa sempre ser posto novamente em prática, que se pode esperar alguma forma de felicidade em Montaigne - uma felicidade difícil, tensa, ativa, mas não menos possível:

[...] Me trouve-je en quelque assiete tranquille? y a il quelque volupté qui me chatouille? je ne la laisse pas friponer aux sens, j'y associe mon ame [...] et l'employe de sa part à se mirer dans ce prospere estat, à en poiser et estimer le bon heur et amplifier. Elle mesure combien c'est qu'elle doibt à Dieu d'estre en repos de sa conscience et d'autres passions intestines, d'avoir le corps en sa disposition naturelle, jouyssant ordonnéement et competemmant des functions molles et flateuses, par lesquelles il luy plait compenser de sa grace les douleurs de quoy sa justice nous bat à son tour, combien luy vaut d'estre logée en tel point que, où qu'elle jette sa veue, le ciel est calme autour d'elle: nul 
desir, nulle crainte ou doubte qui luy trouble l'air, aucune difficulté passée, presente, future par dessus laquelle son imagination ne passe sans offence. (Ibid., p. 1112)

Esta felicidade, no entanto, supõe a satisfação de nossos desejos, pois apenas assim nossa alma estará "en repos de sa conscience et d'autres passions intestines". É para legitimá-la, então, que Montaigne, no último movimento do ensaio, dedicar-se-á a combater a recusa estóica dos prazeres do corpo e a re-instaurar seu lugar em nossa vida, assinalando o caráter 'natural' - espontâneo, forjado pelo hábito - dos apetites que nos levam em sua direção. Acompanhemos, então, o desenlace de Da experiência.

\section{A Reconciliação com o Prazer}

A experiência relativa a seu corpo leva Montaigne, no último movimento do ensaio, a dar um lugar de destaque ao prazer (corpóreo) na vida humana. Experimentando seus apetites como inclinações que lhe são próprias, impulsos que o movem espontaneamente na direção de suas necessidades, Montaigne considera, pois, que reprimi-los implica em violência em relação a si mesmo, e, mais do que isso, que é sinal de desprezo pela condição corpórea do homem e de uma aspiração desmedida por uma perfeição supra humana. A fruição dos prazeres do corpo - fruição temperante certamente, pois, como já vimos, somente nela há verdadeiro prazer -, revela-se, pois, indissociavelmente ligada à virtude, que o estóico, de maneira vã e arrogante, projeta na ação moldada pelo puro dever. Esta virtude humana - nova figura da mediania - é a virtude daquele que conhece a si mesmo e a seus limites e que sabe que o que the 
cabe é viver adequadamente sua vida cotidiana, ordinária - vivê-la "à propos" (De l'Experience, p. 1108)

Nos relatos que Montaigne faz da experiência de seus apetites, já é possível antever elementos da crítica que ele dirigirá, nas páginas finais do ensaio, ao desdém dos estóicos pelos prazeres do corpo. Tanto nas lembranças de infância - seu tutor que procura corrigir-lhe o paladar -, quanto no relato de certos hábitos de corte, verifica tentativas de obstrução da força motriz dos apetites, dos impulsos que lhe são mais próprios e espontâneos, configurando, assim, uma repressão violenta, porquanto contrária a si mesmo. A banalidade dos casos não suprime seu alcance moral:

[...] On a eu en mon enfance principalement à corriger le refus que je faisois des choses que communement on ayme le mieux en cet aage: sucres, confitures, pieces de four. Mon gouverneur combatit cette hayne de viandes delicates comme une espece de delicatesse. [...] Qui oste à un enfant certaine particuliere et obstinée affection au pain bis et au lart, ou à l'ail, il luy oste la friandise. (ibid., p. 1099)

...[je] hay l'opinion de Favorinus qu'en un festin il faut qu'on vous desrobe la viande où vous prenez appetit.

Em ambos os casos, assim como na proposta de submissão dos desejos à frugalidade e à austeridade ("qu'il vaut mieux obliger son desir aux choses plus aisées à recouvrer..." - ibid.), Montaigne vê a repressão dos apetites como vício (“...mais c'est toujours vice de s'obliger”), como orientação a ser particularmente evitada.

Os apetites são forças que nos movem espontaneamente, segundo 
nossa constituição físico-moral, na direção daquilo que nos é necessário, isto é, daquilo que nós, em nossa condição corpórea, precisamos para viver. Tais necessidades não se definem imediatamente por uma legalidade natural que nos transcende, e que seria apenas alcançada pela razão, mas manifestam-se por nossas disposições constituídas, forjadas pelo hábito, através do desejo: "Si ne m'osteront-ils pas de la teste que ce ne soit un tres-convenable mariage du plaisir avec la necessité, avec laquelle, dict un ancien, les Dieux complottent tousjours." (ibid., p. 1114) É tolice, portanto, pensa Montaigne, deixar de satisfazê-los, deixar de entregar-se a estas forças: "A quoy faire desmembrons nous en divorce un bastiment tissu d'une si joincte et fraternelle correspondance? Au rebours, renouons le par mutuels offices." (ibid.) A necessidade verdadeira, corporificada, humana ("intelectualmente sensível, sensivelmente intelectual"), infiltrada em nossas disposições corporais singulares, não se divorcia do prazer.

Compreendemos, portanto, porque o ensaísta afirma que detesta a "sabedoria desumana" (dos estóicos), que desdenham satisfazer seus apetites: "Moy, qui ne manie que terre à terre, hay cette inhumaine sapience qui nous veut rendre desdaigneux et ennemis de la culture du corps." (ibid., p. 1106) Desprezando os prazeres do corpo, ela recusa sua condição corpórea, contraria os impulsos que Ihe são espontâneos, mais próprios e naturais. Os homens que buscam apenas pela razão as necessidades que neles operam (e que buscam, portanto, por ela, o que é verdadeiramente digno de ser apetecido) agem de maneira tão viciosa quanto aqueles que se entregam desmedida e imediatamente - sem a mediação ordenadora dos hábitos - aos prazeres do corpo: 
J'estime pareille injustice prendre à contre coeur les voluptez naturelles que de les prendre trop à coeur. Xerxes estoit un fat, qui enveloppé en toutes les voluptez humaines, alloit proposer pris à qui luy en trouveroit d'autres. Mais non guere moins fat est celuy qui retranche celles que nature luy a trouvées. (ibid.)

É preciso, portanto, aceitar estas forças 'habitualmente' espontâneas que nos movem, satisfazer nossos apetites e fruir os prazeres que nos proporcionam. Não se trata de procurá-los ou evitá-los, mas de aceitá-los, recebê-los, abraçálos: "Il ne les faut ny suyvre, ny fuir, il les faut recevoir." (ibid.) Se há falta de razão, acidentalidade e vanidade em nossos apetites, há ainda mais em exagerar-Ihes a inanidade e, assim, desdenhá-los e evitá-los: "Nous n'avons que faire d'exagerer leur inanité; elle se faict assez sentir et se produit assez. Mercy à nostre esprit maladif, rabat-joye, qui nous desgoute d'elles comme de soy mesme..." (ibid.) Negar nossos apetites é também negar o que somos; por pretendermos ser o que não somos - sábios, retos e inflexíveis:

[...] Moy qui me vente d'embrasser si curieusement les commoditez de la vie, et si particulierement, n'y trouve, quand j'y regarde ainsi finement, à peu pres que du vent. Mais quoy, nous sommes par tout vent. Et le vent encore, plus sagement que nous, s'ayme à bruire, à s'agiter, et se contente en ses propres offices, sans desirer la stabilité, la solidité, qualitez non siennes. (ibid.)

O que é, certamente, colocado em questão pelo ensaísta é a pretensão dos estóicos de agir com base na pura vontade racional e em vista do puro 
dever. Assim, ele desafia estes homens a levarem seu desdém pelos prazeres do corpo às últimas conseqüências - mostrando a insensatez de seus propósitos e, no limite, sua impossibilidade:

[...] Que ne renoncent ils encores au respirer? que ne vivent-ils du leur, et ne refusent la lumiere, de ce qu'elle est gratuite et ne leur coute ny invention ny vigueur? Que Mars, ou Pallas, ou Mercure les sustantent pour voir, au lieu de Venus, de Cerez et de Bacchus. Chercheront ils pas la quadrature du cercle, juchez sur leurs femmes! (ibid., p. 1107)

É, assim, na direção oposta ao esforço do estóico por afastar sua consciência da apreensão sensível do prazer (tentando realizar a ação eventualmente prazerosa apenas por dever), que Montaigne reclama que nos apliquemos à satisfação de nossos apetites: "Je hay qu'on nous ordonne d'avoir l'esprit aus nues pendant que nous avons le corps à table. Je ne veux pas que l'esprit s'y cloue ny qu'il s'y veautre, mais je veux qu'il s'y applique, qu'il s'y sée, non qu'il s'y couche." (ibid.) Não sugere, com isso, que nos entreguemos intemperante e passivamente aos prazeres corpóreos, mas que apliquemos ativamente nossa consciência a eles, que adiramos a eles, fruindo-os integralmente: "Quand je dance, je dance; quand je dors, je dors..." (ibid.)

Ecoa, certamente, nessas passagens (e Montaigne se encarregará, como veremos em seguida, de tornar explícita a aproximação) a noção estóica de consiliatio - a oîkeiosis dos discípulos de Zenão -, o habitar a si mesmo, o querer a si próprio como a natureza o quer.

[...] Nature est un doux guide, mais non pas plus doux que prudent et juste. Intrandum est in rerum naturam et penitus quid 
ea postulet pervidendum. Je queste partout sa piste: nous l'avons confondue de traces artificielles; et ce souverain bien Academique et Peripatetique, qui est vivre selon icelle, devient à cette cause difficile à borner et exprimer; et celuy des Stoïciens, voisin à celuy là, qui est consentir à nature. (ibid., p. 1113)

No entanto, a consiliatio montaigneana, a afirmação da necessidade de consentir à natureza, de abraçar seu movimento em nós, não tem, evidentemente, o mesmo sentido que tem para os estóicos. Para eles, a virtude consiste na adesão consciente e ativa à necessidade racional da própria Natureza que opera no agente; consiste em consentir à Natureza, compreendida como o Lógos universal que tudo penetra. Ora, Montaigne toma a máxima estóica em um sentido completamente distinto e a reinterpreta voltando-a contra eles mesmos. Quando considera que a natureza é um guia "suave", "prudente" e "justo", e que não há porque "romper com suas regras”, ele não se refere à mesma Natureza do estóico (pois, sabe-se incapaz de alcançar a "lei geral do mundo", o Lógos universal que opera em nós); ele o detecta nas inclinações que os hábitos e costumes imprimiram em seu corpo, nas suas inclinações 'naturais'. O estóico, ao pretender, arrogantemente, conhecer e conformar-se às leis da Natureza, contraria, finalmente, a sua natureza, corpórea, habituada, a única natureza a que podemos aceder, posto que a outra se oculta irremediavelmente sob os "traços artificiais" desta natureza singular que nos impregna, que nos constitui.

É porque o estóico busca conformar-se à Natureza, e não à sua natureza - erigindo uma medida externa, e não própria para suas ações - é 
que ele busca uma perfeição supra humana, inadequada à nossa condição. Ora, a virtude que ele projeta na retidão racional absoluta da ação (e que se exprime de modo perfeito, acabado, na magnanimidade do sábio), Montaigne a traz de volta para a terra, para o mundo propriamente humano: "La grandeur de l'ame n'est pas tant tirer à mont que tirer avant, comme sçavoir se ranger et circonscrire. Elle tient pour grand tout ce qui est assez, et montre sa hauteur à aimer mieux les choses moyennes que les eminentes." (ibid., 1110) A verdadeira virtude, mostra, pois, o ensaísta, não está nas ações eminentes, extraordinárias, mas em "amar as coisas medianas" e em "saber se alinhar e circunscrever", isto é, dar ordem à própria vida, manejá-la e adequar a ela nossa conduta. Trata-se, verifica Montaigne, de uma virtude muito mais difícil e mais nobre que a pretendida pelo estóico, já que para ela não há parâmetros de orientação pré-estabelecidos, nem referencial algum que nos permita saber até onde podemos ir antes de cairmos em erro (enquanto os que almejam a eminência têm sempre, como referência, as ações máximas dos sábios): "Le peuple se trompe: on va bien plus facilement par les bouts, où l'extremité sert de borne d'arrest et de guide, que par la voye du millieu, large et ouverte (...) mais bien moins noblement aussi, et moins recommandablement." (ibid.) “Desempenhar bem e devidamente o papel de homem”, diz o autor, é o que há de mais "belo e legítimo"; "saber viver esta vida" (nossa vida de homens) "bem e naturalmente" (isto é, de acordo com o que nos é habitual e espontâneo) é a ciência mais árdua que existe. "Desprezar nosso ser", ao contrário, é "a mais selvagem de nossas doenças" (ibid.). O estóico, portanto, aspirando uma perfeição supra humana - aspirando uma condição divina - põe-se aquém do humano. 
Viver nossa vida cotidiana, corriqueira, própria, é - ensina a Montaigne sua experiência - a "ocupação ordinária" de nossa vida. E mais que isso: "C'est non seulement la fondamentale mais la plus illustre de [nos] occupations" (ibid., p. 1108). A grandeza e a glória que cabem a nós, homens, não estão, pois, nas grandes ações, nos grandes feitos ou nas grandes conquistas do espírito ("composer des livres, (...) gaigner (...) des batailles et provinces", "regner, thesauriser, bastir"); tudo isso é menor, secundário (“n'en sont qu'appendicules et adminicules" - ibid.), diante do verdadeiro fim que devemos buscar: "viver", ou, mais do que isso, "vivre à propos", sabendo "meditar e manejar [nossa] vida", compondo nosso comportamento, buscando viver de acordo com aquilo que nos é próprio e apropriado, de modo a alcançar "a ordem e a tranqüilidade em nossas condutas" (ibid.).

O modelo máximo desta virtude - mostrará Montaigne - é Sócrates, justamente aquele que, pelo conhecimento de seus próprios limites - pelo reconhecimento sempre renovado da fragilidade do próprio saber - não quer ser mais do que é (homem), não aspira a ser deus. Vive sua vida banal, corriqueira, com ordem e tranqüilidade, fruindo em toda sua extensão os prazeres ordinários que a vida lhe dá - sabendo ser homem a tal ponto que adquire a graça da divindade ${ }^{52}$ :

[...] Et parmy tant d'admirables actions [...] il n'est chose plus remercable en Socrates que ce que, tout vieil, il trouve le temps de se faire instruire à baller et jouer des instrumens, et le tient pour bien employé. [...] cet homme là estoit-il convié de boire à lut par devoir de civilité, c'estoit aussi celuy de l'armée à qui en demeuroit l'avantage; et ne refusoit ny à jouer aux noysettes 
avec les enfans, ny à courir avec eux sur un cheval de bois; et y avoit bonne grace; car toutes actions, dict la philosophie, siéent également bien et honnorent egallement le sage."

52 "D'autant es tu Dieu comme Tu te recognois homme." (ibid., p. 1115) 


\section{Conclusão}

O estudo que aqui se encerra teve como objeto o ensaio Da experiência, texto que põe fim aos Ensaios de Michel de Montaigne e Ihes dá seu tom final, recolhendo e retomando uma série de concepções e reflexões desenvolvidas ao longo da obra e referentes aos mais diversos temas e campos, como a crítica do conhecimento, da cultura humanista, o papel formador dos costumes, a noção de natureza, a relação com o corpo, com o prazer, com a morte etc. Num certo sentido, julgamos profícuo tomar especificamente este ensaio como objeto de estudo por sua própria abrangência, a qual o texto alcança, no entanto, por meio de um eixo muito bem determinado: a recusa de toda pretensão de regulação de nossas condutas a partir de um conjunto de normas assentadas em um conhecimento de essências ou das leis da natureza. $O$ esclarecimento desta recusa, e, sobretudo, dos parâmetros para a orientação de nossas condutas que Montaigne propõe no lugar daquela pretensão normativa, foi, na verdade, o motivo real que nos moveu ao longo deste estudo, pois acreditamos se tratar de uma chave para a compreensão da própria empresa dos Ensaios, cujo horizonte essencialmente ético - em que se destacam a exigência de liberdade, a recusa de toda violência e a recuperação do prazer - se desenha sob a afirmação da autonomia sobre a heteronomia, da autenticidade sobre a inautenticidade. De fato, é pelo esclarecimento do papel da experiência de si nesta relação tensa do sujeito moral com as formas de heteronomia que se the impõem como ser social que acreditamos poder compreender o sentido desta obra em que Montaigne, mais do que meramente se retratar, compõe-se, forma-se. 
Como é próprio da natureza do ensaio (o que o torna, num certo sentido, avesso a toda tentativa de escandi-lo em uma 'estrutura' clara e distinta), os movimentos crítico e propositivo que procuramos descrever neste estudo encontram-se dispersos (ou melhor, entrelaçados) ao longo do texto. Neste entrelaçamento, como vimos, Montaigne toma como alvo as artes da jurisprudência e da medicina, assim como o saber prático formulado pelos estóicos, todos pretensamente apoiados sobre um conhecimento mais ou menos certo de essências (como é o caso da jurisprudência) ou das regularidades da natureza (como na ética estóica ou na técnica médica) conhecimento consolidado na forma de um conjunto de regras (uma doutrina) que se querem capazes de orientar com eficiência nossas condutas em direção à justiça, à saúde e à felicidade.

Esta pretensão de eficiência ou de alguma garantia de sucesso de nossas condutas, como vimos, parece ser o ponto em que se inicia a divergência entre Montaigne e tais formas de saber; pois é ela que leva os homens a buscar fundar suas práticas sobre uma ciência, um conhecimento objetivo das normas de suas ações e da realidade sobre a qual elas incidem, sendo ela, portanto, responsável, em última instância, pela violência que deriva das tentativas de aplicação desse conhecimento fixo e geral a uma realidade que se revela sempre móvel e atravessada pela particularidade. A pretensão de eficácia e o esforço de fundamentação das práticas que dela deriva - como vimos - são atacados pelo ensaísta desde as primeiras linhas do $D a$ experiência, em que Montaigne mobiliza meramente a título de argumento uma concepção da natureza e do campo das práticas humanas que põe em xeque toda pretensão regulatória das artes. À medida que os homens buscam trazer 
alguma segurança para suas práticas e que, para tanto, formulam e consolidam - na forma de uma doutrina - regras destinadas a orientar suas ações futuras, eles esbarram - assinala Montaigne - em uma realidade sempre diversa e particular, portanto avessa à regulação por meio de normas fixas e gerais.

Procuramos assinalar que as artes, nesse sentido, padecem - para Montaigne - de uma dificuldade inerente à sua própria compreensão e articulação interna. Jurisprudência, medicina e as artes de viver - como vimos - não são capazes de orientar as ações devido à desproporção, ao mesmo tempo quantitativa e qualitativa, entre suas normas - sempre poucas, gerais e fixas - e a realidade - atravessada pela particularidade, multiplicidade e mudança de todas as coisas e eventos. 'Se as normas morais são tão difíceis de se estabelecer', considera Montaigne, 'não é de se surpreender que as leis que regem a vida de tantos homens sejam ainda mais difíceis de se produzir'. O mesmo vale para as artes de viver e para a medicina. Pois as primeiras, na forma de verdadeiros manuais de moralidade, oferecem uma classificação de virtudes, paixões, caracteres e gêneros de vida que, na forma de modelos gerais e abstratos, têm um efeito de orientação inócuo para situações morais sempre particulares. Da mesma forma, a medicina, ignorando a radical intervenção dos costumes sobre nossa constituição física - intervenção que a forma e diversifica -, funda prescrições vazias em representações abstratas e gerais de nossos corpos - como as compleições fleumática, sangüínea, melancólica e colérica da escola hipocrática -, calcadas em um pretenso conhecimento da natureza psicofísica dos homens. Mais do que apenas incapazes de nos orientar - adverte Montaigne - medicina, jurisprudência e artes de viver nos violentam, à medida que procuram forçar a singularidade de 
nossos corpos e constituições morais e sociais à generalidade de suas prescrições.

Como pudemos observar, no entanto, os próprios técnicos têm ciência das dificuldades inerentes à sua prática. Consideram, nesse sentido, que a distância entre normas e casos deve ser superada pela experiência do técnico, só ela capaz de levá-lo a reconhecer a particularidade dos casos e a flexibilizar, em sua função, as normas da arte. A princípio, como vimos, Montaigne guarda simpatia por esta concepção de técnica. É por isso que considera mais felizes que a França de sua época, sufocada sob uma infinidade de leis que tentam abarcar a realidade, as nações que têm leis em pequeno número, simples e gerais - nações nas quais cabe ao discernimento do juiz fazer justiça, aplicando as leis à luz das circunstâncias do caso.

Esta concepção de técnica, que faz apelo à experiência e habilidade de quem a executa, não é, no entanto, a única, mas é acompanhada por uma outra, que com ela rivaliza desde os tempos da polêmica entre racionalistas e empiristas no interior da medicina hipocrática. Segundo esta outra concepção, a eficácia da arte não pode ser deixada à mercê da experiência ou habilidade do técnico - que é sempre contingente - mas deve ser assegurada (tanto quanto a interferência do acaso o permita) pela qualidade das normas, que devem alcançar e exprimir no nível do discurso - isto é, objetivamente - as relações de causalidade que regem a realidade.

Ora, esta pretensão de assentar as práticas num discurso que alcance e exprima a realidade das coisas, como vimos, é questionada por Montaigne já nas primeiras linhas do ensaio, em que a busca do legislador e do jurista por aprimorar a qualidade das leis - especificando as que são muito gerais e 
esclarecendo as que são muito obscuras - revela-se não apenas falaciosa, mas ainda nociva, visto que compromete, paradoxalmente, a mínima perspectiva de justiça que se pode esperar que o juiz alcance na execução das leis. A especificação das leis - argumenta Montaigne - não suprime em definitivo a distância entre a norma e o caso, nem as interpretações eliminam em absoluto as dúvidas acerca de sua aplicação: ao contrário, tal atividade apenas multiplica o universo de referências que o juiz deve considerar na discriminação dos casos e dificulta a construção de seu veredito.

Neste contexto, a glosa jurídica - e ainda o comentário de textos em geral - é tomada pelo autor como paradigma da busca vã pelo conhecimento efetivo das coisas. A interpretação - como vimos Montaigne argumentar - não apenas não chega ao objeto que se propõe alcançar - pois o texto é sempre tomado por leitores que nunca são os mesmos e para os quais ele sempre se apresenta em determinada perspectiva - mas, ainda, o destrói sob o esforço da análise, que, segmentando-o, o faz perder sua unidade, coesão e delimitação, multiplicando-o em inúmeros novos objetos. Pior do que isso, a interpretação se torna ela mesma objeto de novas interpretações; coloca-se como barreira que veda o acesso ao texto a que pretendia conduzir - rede de significados que o intérprete cria e em que ele próprio se enreda. O destino da interpretação, enfim, é o de passar de meio a fim: é a cultura vazia e formal da erudição, dos comentários sobre comentários, que Montaigne critica no movimento humanista de seu tempo.

Esta conversão perniciosa dos meios em fins, pela qual é responsável a busca obsessiva pela objetividade no conhecimento, surge, no plano da prática, como fruto da busca incessante por garantias de eficiência. Montaigne 
expõe este mecanismo insidioso, como vimos, no registro da jurisprudência. $\mathrm{Na}$ medida em que a eficácia da arte jurídica pretende se desvincular totalmente da experiência ou habilidade daquele que a executa - o juiz - e identificar-se sem mais à qualidade das leis, estas adquirem autonomia, como expressão objetiva do conhecimento de essências - a natureza dos casos apreciados -, e passam a ser obedecidas e aplicadas de forma inflexível, afastando definitivamente o horizonte da justiça.

A técnica, portanto, parece sofrer de um dilema. Se a distância entre as normas que a constituem e os casos (a que visa regular) leva ao erro e à ineficácia, toda tentativa de contornar esta contradição - que lhe é inerente por meio do aprimoramento de suas normas apenas potencializa sua ineficiência, conduzindo a uma massa de regras e sub-regras dificilmente manobrável, cuja aplicação (que se quer, então, cada vez mais certa e inflexível) se torna prioritária em relação à produção dos fins a que originalmente se propôs: fazer jus aos casos. A saída para este impasse, a princípio, estaria na outra concepção de arte a que aludimos anteriormente, que atribui à experiência e habilidade do executor das normas um papel fundamental para o sucesso da técnica - o qual, no entanto, é necessário assumir como nunca efetivamente assegurado.

Do ponto de vista montaigneano, contudo, esta saída não faz da arte o saber em que devemos buscar a orientação de nossas condutas. Certamente, como vimos, o autor considera preferível um sistema jurídico que tenha menos leis e dê mais poder para juízes experientes, assim como um médico menos preocupado em fazer valer a doutrina que aprendera na escola e mais atento ao modo muito particular como se manifesta a doença no corpo daquele doente 
em específico. Ainda assim, no entanto, a arte permanece no interior de uma concepção essencialista do mundo. Ainda que precise da experiência - do 'olho' - para que suas normas sejam aplicadas em um mundo em que a matéria e o tempo introduzem indeterminação nas coisas, a arte, ainda assim, supõe a existência e a possibilidade de acesso a normas objetivas. É exatamente contra esta ilusão, como vimos, que Montaigne se ergue, considerando que as artes operam por meio de normas que, na verdade, fundam-se ou no arbítrio dos homens ("autores vãos e incertos"), como é o caso das leis no âmbito da justiça, ou em um conhecimento muito duvidoso das regularidades da natureza (na verdade inapreensíveis), o caso das prescrições morais das artes de viver (os kat' orthoma do estoicismo) ou das prescrições relativas ao corpo, no campo da medicina. No primeiro caso - diz Montaigne - 'os comandos das leis produzidas pelo homem são tão confusos e inconstantes que chegam a justificar o erro dos juízes em sua aplicação e mesmo a desobediência da parte dos cidadãos'. No outro, as prescrições são tão variadas e incertas que, 'se nosso médico prescreve uma dieta contrária à de nossos hábitos, devemos procurar um outro, pois certamente encontraremos um cuja autoridade avalizará nosso modo de vida'.

Como vimos, então, é em outra instância que Montaigne busca os parâmetros para a orientação de suas condutas. Não mais em um saber normativo que se impõe às ações do exterior - e que, por sua exterioridade, permanece como expressão de violência - mas em um saber proporcionado pela volta a si, pela observação, em si mesmo, do que convém, no registro das condutas privadas e no cuidado do próprio corpo. Já no registro público, a passagem das normas da arte para a experiência de si não traz consigo a 
desobediência das leis, mas instaura uma obediência refletida, uma adesão distanciada, em que ao reconhecimento da necessidade de respeito às leis (não por serem expressão da Justiça, mas por constituírem e garantirem o vínculo possível entre os homens) associa-se um distanciamento crítico, uma livre interrogação acerca de seu valor e legitimidade. Mas que não se pense, com isso, que a liberdade proposta por Montaigne é meramente interior, pois ele escapa ao jugo das leis por uma obediência que folga em não ser sequer tocada por elas. Enfim, não se trata de propor a ausência de normas, mas de afastar toda forma de heteronomia e de afirmar a autonomia do sujeito - que, a partir do recuo crítico trazido pela experiência de si, restitui às leis e costumes seu valor e legitimidade próprios, tornando-os passíveis, então, de uma livre adesão.

Mas, por que a experiência de nós mesmos nos fornece um solo melhor para a orientação de nossas condutas? Ora, porque, por meio dela, conhecemo-nos não de maneira abstrata e geral, enquadrando-nos em tipos fixos e pré-estabelecidos, mas nos aproximamos de nossa singularidade, daquilo que nos constitui mais propriamente. Pois, como vimos, o olhar para si nunca é meramente intelectual, pura potência de abstração que identifica e assinala traços gerais, mas atravessado pela sensibilidade, que ilumina e destaca no sujeito sua própria singularidade: mais do que 'experiência de si', devemos falar em 'vivência de si'. E a observação e exame atento de nós mesmos, a rememoração de nossos erros passados, adverte-nos para os erros futuros, advertência tanto mais forte e eficaz quanto atravessada por uma carga afetiva que, em circunstâncias semelhantes àquelas em que erramos outrora, alerta-nos vivamente sobre os efeitos possíveis de nossas ações. 
Contudo, como pudemos observar, não é esta ainda a lição maior trazida pela experiência de si. Como já bastante repisado pela tradição de comentário que interpreta os Ensaios à luz do ceticismo, sabemos que a experiência de seus erros passados leva Montaigne a aprender sua própria fragilidade intelectual e moral - a imbecilitas da condição humana -, aprendizado que produz a suspensão do juízo e conduz à atitude examinadora (no plano intelectual) e à modéstia e moderação (no plano moral). A abertura para a investigação - isto é, novamente, para a experiência - põe o juízo em movimento, exercita-o e forma-o, sendo este juízo, fundado numa relação com o particular, o verdadeiro ganho obtido com a experiência de si.

O ensaio que nos propusemos a examinar, no entanto, não se limita a apresentar a experiência de si como o solo a partir do qual devem se orientar as condutas de cada um. Mais do que isso, ele é o espaço em que Montaigne apresenta sua própria experiência. Ou ainda mais: é o terreno em que observamos esta experiência em ato, sendo não apenas relatada, mas realizada pelo autor. Ora, é na relação com seu corpo que vemos Montaigne examinar-se a si mesmo, opondo a conduta que "tanto fez por sua saúde" ao discurso vazio da medicina, cego em relação ao doente e à doença que the afeta.

Para a medicina, o estado natural de saúde do corpo é abalado (e aqui ressaltamos que Montaigne não se ocupa das doenças congênitas) por fatores contrários à constituição física natural do indivíduo, sejam fatores casuais e independentes de sua vontade, sejam comportamentos que ele adote. Seguindo hábitos contrários à natureza de seu corpo, o indivíduo adoece. Para que recupere sua saúde, o médico the recomenda o abandono dessas 
condutas e a adoção daquelas que, por natureza, são conformes à sua compleição corporal. A medicina adota, portanto, em suas concepções de saúde e de doença, uma visão naturalista do corpo, segundo a qual este é por natureza inclinado a tal ou tal modo de vida.

A experiência do próprio corpo ensina a Montaigne, no entanto, que são os hábitos que ele adota desde sua mais tenra infância que forjam sua compleição corporal. Nesse sentido, não é possível dizer que existem hábitos por natureza favoráveis ou desfavoráveis à compleição física do indivíduo, apenas que existem comportamentos favoráveis ou desfavoráveis enquanto mais próximos ou afastados daqueles que ele adotou e incorporou, e que, por instaurarem regularidades em seu corpo, constituem seu estado de saúde - 0 equilíbrio da normalidade. A doença, dessa forma, é fruto de qualquer fator que venha a comprometer a regularidade instaurada pelo hábito - seja um fator casual e independente da vontade do indivíduo, seja um comportamento que ele adote e que contrarie os costumes de seu corpo. E ele adoece se não teve o cuidado de variar seus hábitos de vez em vez, mas se os deixou se cristalizar, de forma a não poder suportar nenhum tipo de mudança em seu modo de vida. De outra forma, avalia Montaigne, a doença virá 'par fortune', por acaso, pois o indivíduo, variando aqui e ali seus modos de vida, mantém o horizonte de sua saúde, não importando as vicissitudes e situações adversas em que se encontra.

Se o impacto das mudanças de vida sobre o corpo depende do quanto este se fixou em seus próprios hábitos, é o exercício da flexibilidade em relação a estes, então, que deve instaurar a saúde como um horizonte constante, um estado tenso, sempre posto à prova por uma nova mudança, que o exercita, o 
fortalece. A variação dos hábitos opera um alargamento no registro do que surge como 'normal' para o sujeito, estende o âmbito de sua constituição. O corpo, desse modo, aparece em Montaigne como o espaço para o exercício da autonomia, da liberdade, em que devemos lutar para não nos tornar escravos de nossos próprios hábitos, para ampliar o arco de nossas possibilidades, instaurando uma disposição para o múltiplo.

Esta relação ativa e tensa com o próprio corpo, no entanto, não vale para o homem doente e para o homem de idade. O primeiro, sem dúvida, não recuperará sua saúde pondo à prova as regularidades de seu corpo, das quais justamente fora desalojado. O segundo, enrijecido pelo tempo, está fora do alcance da educação: tem sua saúde assentada em um arco de possibilidades muito pequeno. Em ambos os casos, portanto, há que se manter os hábitos com que seus corpos se acostumaram, como única medida para recuperar a saúde, no primeiro caso, e evitar a dor desnecessária, no segundo. Devem, nesse sentido, permanecer usufruindo dos prazeres que seus hábitos lhes proporcionam, prazeres que seus corpos buscam espontaneamente, habitualmente, e que, portanto, coincidem com sua saúde.

Montaigne, dessa forma, propõe a recusa de toda prescrição médica, que, em nome de um suposto conhecimento da natureza dos corpos, afasta o doente dos hábitos em que se formou e, portanto, do horizonte de sua saúde, prometendo alívio dos males e trazendo apenas dor, violência. Com isso, o autor não sugere o abandono de todo enfrentamento da doença, apenas propõe que o doente, mantendo seus hábitos, colabore para que seu corpo retorne espontaneamente para seu estado de saúde, e, deixando a doença seguir seu curso natural, conduza-a a uma morte igualmente espontânea, tão 
casual quanto foi seu surgimento. $\mathrm{E}$, diante do último dos argumentos a que o médico apela - 'mas você pode morrer agindo assim!' - lembra os tantos que morreram cumprindo à risca toda orientação de seus médicos, e, ainda, que, no limite, nossa morte não é conseqüência de uma ou outra atitude que tomemos, mas fato inexorável, parte integrante de nossa condição corpórea cujo medo que nos provoca devemos aprender a 'souffrir doucement', a padecer suavemente.

Ora, padecer suavemente o medo da morte, assim como as dores físicas e psíquicas em geral, consiste em saber vivê-las sem lhes dar importância ou prestar-Ihes atenção, mas, ao contrário, em reduzi-las na sua duração e no seu significado por meio do desvio da própria consciência que, voltando-se para outros objetos ou realidades agradáveis - em uma palavra: distraindo-se - faz toda dor 'escoar', passar de maneira fugidia, efêmera, afetando de maneira menos sensível aquele que a experimenta. $O$ mesmo mecanismo - que, no plano dos discursos, tem na amplificatio retórica seu equivalente - Montaigne propõe para a relação com o prazer. Isto é, que o sujeito amplie o prazer que experimenta em sua duração e significado, aplicando-Ihe vivamente não só os sentidos, mas a consciência, fruindo-o passo a passo, lentamente, alcançando-o em toda sua profundidade e extensão, detendo-o ou ao menos o retardando no tempo - tornando seu efeito e sentido mais vivo, pleno. É desse controle sobre os estados de prazer e de dor, controle sempre difícil e que precisa ser sempre novamente posto em prática, que se pode esperar alguma forma de felicidade em Montaigne - uma felicidade difícil, tensa, ativa, mas não menos possível.

'Mas' - poderíamos nos perguntar - 'Montaigne sugere com isso uma 
entrega imoderada aos prazeres do corpo? Esta pergunta nos remete imediatamente ao último movimento do ensaio. Se a experiência do próprio corpo leva o ensaísta a recuperar o lugar do prazer sensorial nas linhas finais do Da experiência, também o leva a expor o tecido fino no qual prazer e virtude se entrelaçam. É neste terreno - o da relação entre virtude e prazer, corpo e alma - que Montaigne enfrenta diretamente a ética estóica e sua concepção de virtude, como ação realizada em nome do puro dever.

A experiência do próprio corpo leva Montaigne a perceber seus apetites como inclinações que Ihe são próprias, habituais, espontâneas - inclinações que o conduzem na direção do que lhe é necessário, e cuja satisfação, portanto, é legítima. Toda contenção ou repressão dos desejos lhe aparece, portanto, como tolice, ou, mais do que isso, como forma de violência. Com isso, Montaigne não defende a entrega imoderada aos prazeres - a intemperança apenas assinala que a verdadeira temperança não se encontra na contenção dos apetites, mas na moderação desejada, acompanhada de prazer e realizada 'espontaneamente' - virtude forjada pelo hábito e consubstancial ao agente.

Para o estóico - e desde já apresentamos a figura combatida pelo autor - a temperança (assim como a coragem e todas as demais virtudes) somente é uma virtude à medida que se realiza em vista do puro dever, não em vista do prazer, pois somente há mérito na ação realizada pelo puro dever. Para o estóico, portanto, a virtude da temperança somente pode se expressar na forma da contenção dos apetites, na moderação forçada dos prazeres, buscada não pelo desejo e com vistas ao prazer, mas pela razão e com vistas ao dever. O estóico entende que nossas necessidades se definem por uma legalidade natural que nos transcende (o conjunto das leis da natureza) e que 
somente pode ser alcançada pela razão, que deve ser a única a nos conduzir na satisfação de nossas necessidades naturais, da qual o desejo está totalmente desvinculado.

Ora, é exatamente disto que Montaigne zomba, isto é, de alguém que desvia sua consciência dos momentos de prazer apenas para que a satisfação de suas necessidades seja realizada em nome do puro dever. Para Montaigne, se nossas necessidades têm algum lastro em uma legalidade natural (a que, a bem dizer, não temos acesso pela razão), é em nossas disposições adquiridas (que o hábito desde sempre sedimentou sobre nossa natureza) que elas se manifestam, através do desejo. A necessidade efetiva, nesse sentido, isto é, a necessidade corporificada, humana, infiltrada por nossas disposições corporais, não se divorcia do prazer.

Mas, do ponto de vista de Montaigne, esta cisão que o estóico estabelece entre o dever e o prazer tem um motivo claro: ela deriva de uma concepção específica do que seja a consiliatio (a oikeiosis, o 'habitar-se a si mesmo', 'querer a si próprio como a natureza o quer'). Para os estóicos e para Montaigne, a virtude consiste na consiliatio, isto é, em 'consentir à natureza', 'abraçar seu movimento em nós'. Do ponto de vista do estóico, no entanto, a consiliatio é uma adesão racional à necessidade da própria natureza, compreebndida como o lógos universal que tudo penetra e que opera no agente. Para Montaigne, diferentemente, a consiliatio consistiria numa adesão consciente e ativa à necessidade que se manifesta nas inclinações desiderativas que os hábitos e costumes imprimiram em nossos corpos. O erro da consiliatio estóica, para Montaigne, vem do fato dela repousar numa falsa crença no acesso às leis da natureza por meio da razão, e numa falsa 
concepção da natureza como razão universal. Ao pretender conhecer e se conformar às leis da natureza, o estóico ignora e contraria a sua natureza, desiderativa, corpórea, atravessada e moldada pelo hábito, única 'natureza' a que podemos de fato aceder. A busca estóica por uma autenticidade nascida do encontro do indivíduo consigo mesmo no seio da razão universal termina se revelando, para Montaigne, a mais pura inautenticidade. Pois ele erige, para suas ações, uma medida externa, não própria; age contra suas disposições, isto é, contra os condicionamentos e limites que seu próprio ser (forjado no encontro da natureza com os costumes) Ihe impõe.

Mais do que isso, o estóico, identificando a virtude com a ação em vista do puro dever, erige e busca uma virtude divina, uma perfeição sobre-humana, alheia à nossa condição. Em contraposição, Montaigne reivindica 0 consentimento à nossa natureza, à nossa condição corpórea, aos nossos hábitos e costumes, e, enfim, aos nossos desejos. Trata-se, portanto, de uma reivindicação de autenticidade, de adesão a si, aos condicionamentos e limites que nosso próprio ser nos impõe, da recusa de toda aspiração a uma perfeição divina, sinal de presunção e arrogância, e motivo de dor e violência.

Montaigne, enfim, traz a virtude de volta para o mundo dos homens, sob uma nova forma da mediania, virtude muito mais difícil de ser alcançada e praticada que a virtude pretendida pelo estóico, já que para ela não há parâmetros pré-estabelecidos, nem referencial que nos permita saber até onde podemos ir antes de incorrermos em erro.

A verdadeira virtude, enfim, não se caracteriza pela eminência, pela grandiosidade, mas pela suficiência: o virtuoso sabe se circunscrever - isto é, conhece seus limites e age conforme eles. Porém, ordenadamente, sabendo 
manejar e dar ordem à própria vida, uma vida corriqueira, cotidiana, não uma vida grandiosa e eminente: em suma, é num Sócrates muito peculiar que, para Montaigne, está o modelo do homem virtuoso. 
ANEXOS 


\section{ANEXO I}

\section{A Querela das Artes}

A Querela, que se desenvolveu sobretudo durante o Quattrocento italiano, mas que certamente teve ressonâncias em grande parte da Europa até o século XVI - como se pode constatar em certos textos de autores como Melanchthon ${ }^{53}$-, definiu-se em grande medida como um debate centrado na noção de 'dignitas hominis' e na questão da via pela qual "o homem pode realizar mais completamente a própria perfeição" - se pela 'vida ativa' ou pela 'vida contemplativa' (COLOMBERO, p. 39). A 'Querela' se deu entre os defensores da Jurisprudência e os da Medicina, assumindo-se a "identificação do Direito com a vida ativa e da Medicina com a especulação pura" ${ }^{54}$ Os médicos afirmavam a superioridade da Medicina e os juristas a da Jurisprudência, ambos considerando que a 'arte' defendida implicaria numa 'forma de vida mais nobre'.

Para os primeiros, a maior nobreza da Medicina em relação à Jurisprudência viria de que ela - por representar a 'vita contemplativa', 'speculativa' - seria a única atividade capaz de produzir a "vera felicità" (VERNIA, in COLOMBERO, P. 54). Por outro lado, de acordo com os juristas, a Medicina seria menos nobre que a Jurisprudência porque esta representaria a "vita attiva", que é "in ogni modo preferibile" (SALUTATI, in COLOMBERO, p. 
51), pois "s'afferma di tutte l'opere umane, niuna essere più prestante, maggiore, né più degna, che quella che si esercita per accrescimento e salute della patria” (PALMIERI, in COLOMBERO, p. 58).

Embora a 'Querela' tenha assumido em grande medida o sentido de disputa acerca do registro da afirmação da 'dignitas hominis', de polêmica sobre as noções de 'vita attiva' e 'vita contemplativa', esta configuração do debate, segundo Eugenio Garin, teria sido tardia, ou seja, "ultrapassava e modificava a discussão tradicional". ${ }^{55} \mathrm{Em}$ suas origens, de acordo com o historiador italiano, a Querela teria sido determinada sobretudo pelo comentário averroísta do De anima, onde Aristóteles teria desenvolvido uma hierarquia das ciências ou segundo a 'certeza do método', ou segundo a 'dignidade do objeto', 'argumentos' a partir dos quais tanto médicos quanto juristas procurariam fundamentar a dignidade de sua disciplina. ${ }^{56}$

A idéia de 'certeza do método', elemento fundamental a partir do qual se desenvolveu o debate, permite-nos compreender como, já na sua configuração originária, a "Querela das Artes" tinha em grande parte um sentido epistemológico. O argumento da 'solidez dos fundamentos', mais tarde

${ }^{53}$ MELANCHTHON, PHILIP - "On the honor of Medicine" e " On the honor of Law", in Orations on philosophy and education, Cambridge University Press, New York, 1999

${ }^{54}$ Eugenio Garin, em sua Introdução à coletânea La Disputa delle Arti nel Quattrocento, Vallecchi Editore, Firenze, 1947, p. XVI.

${ }^{55}$ Idem, ibid.

${ }^{56}$ Introdução a La Disputa delle Arti nel Quattrocento, Vallecchi Editore, Firenze, 1947, p. XIV: “il tema e l'impostazione della questione circa la nobilità delle scienze, almeno come si profilò nel '400, seguiva puntualmente il primo commento d'Averroè al De anima, ove, appunto, si 
agregado ao da 'certeza do método', apenas reforça essa idéia sobre os critérios de definição da nobreza da ciência na disputa.

$\mathrm{Na}$ obra de Salutati, por exemplo, podemos observar ambos os argumentos:

La scienza giuridica (...), traendo principio dalla natura e dalle prime e somme norme di giustizia innate alle menti umane, procede dalla causa all'effeto, procedimento che è detto propter quid." (...) "La Medicina, invece, (...) trae origine (...) dalle proprietà delle cose (...), trae principio dall'esperienza; (...) si riduce, o dovrebbe ridursi, a canoni e regole desunti con l'esperienza da molti casi particolari." (...) "il medico giunge alla regola muovendo dall'effetto, procedimento che i logici sono soliti chiamare scientia quia." (...) "Intelletto, ragione e volontà, daí quali nasce la legge scritta, sono certo più nobili delle forze e delle proprietà di qualsiasi cosa corporea, dalle quali deriva la Medicina; e il bene e il giusto, sui quali si fonda l'arte giuridica, sono più nobili della fallace esperienza delle cose, sulla quale si fonda l'arte della Medicina. (SALUTATI, in COLOMBERO, pps. 48/49)

Já nos textos de um defensor da Medicina como Bracciolini, o argumento da 'estabilidade dos fundamentos' é mobilizado junto ao da 'dignidade do objeto':

Di quanto la morale è inferiore alla filosofia naturale, di altrettanto le leggi sono inferiori alla Medicina. (...) vostre leggi

profilava una gerarchia delle discipline o secondo il metodo (...) o secondo la dignità dell'oggetto", 
(...) sono comprese nella filosofia morale, dottrina che (...) varia secondo i tempi (...). Infatti i costumi non sono sempre gli stessi, e ciò che una volta viene considerato utile, con il tempo diviene molto spesso il contrario. Tali sembrano le leggi. Infatti sono varie, o piuttosto diverse, poiché quasi ogni singolo stato si stabilisce il proprio diritto, che viene detto civile. (...) La Medicina ha invece un fondamento più stabile, in quanto deriva dalla (...) natura, che è sempre la stessa, e non viene soppressa o modificata secondo l'arbitrio di chiunque, non nasce dai tentativi degli uomini o dei popoli e prescinde anche dall'approvazione della plebe: uomini, popoli e plebe che sono soliti stabilire quelle leggi e quel diritto che ritengono poter essere loro utili. E così, quanto una cosa stabile, immutabile e solida è più forte di una cosa leggera, instabile e fondata sull'arbitrio degli uomini, altrettanto la nostra dottrina appare più eccellente del vostro diritto. (BRACCIOLINI, in COLOMBERO, p. 52)

Vernia, por sua vez, elabora sua defesa da Medicina agregando ao argumento da 'certeza do método' o da 'dignidade do objeto':

È più nobile di un'altra la scienza che segue un metodo più nobile (...) per la certezza della dimostrazione. Tale è la Medicina: infatti essa si serve talvolta del procedimento quia e talvolta del procedimento propter quid, e nelle sue dimostrazioni è consapevole di dimostrare, mentre l'opposto accade nel diritto..." (...) "La Medicina è una nobile scienza, subordinata alla filosofia naturale che, quanto a nobilità, non può essere 
paragonata al diritto civile, perché la conoscenza del diritto no può essere detta propriamente scienza..." (...) "Le nozioni o le conoscenze di cose indeterminate, variabili e bisognose di direzione, sono indeterminate e irrazionali, e non possono essere in alcun modo considerate come scientifiche: le nozioni di diritto civile sono appunto tale..." (...) "La scienza riguarda cose immutabili e eterne e non nasce di ciò che è variabile e indeterminato (...) la legge concerne le azioni umane, riguardo alle quali è impossibile stabilire una norma universale del vero [...] (VERNIA, in COLOMBERO, pps. 53 e 54)

Partimos, pois, desta posição central dos argumentos da 'certeza do método' e da 'solidez dos fundamentos' como critérios para a definição da 'nobreza da ciência', para enfatizar, dentre os múltiplos sentidos da 'Querela', seu interesse epistemológico. Sublinhando, desse modo, a afinidade de intenções que existe entre os litigantes e Montaigne (os primeiros visam desqualificar epistemologicamente a disciplina defendida pelos adversários, e o segundo almeja fazê-lo para ambas) e seu desdobramento na fina sintonia de argumentos entre os textos dos querelantes e muitas passagens de $D a$ experiência, acreditamos ser possível demonstrar que a crítica montaigneana à Medicina e à Jurisprudência tem a 'Querela das Artes' como referente cultural mais próximo, aquém da discussão mais ampla e contundente do ensaísta com as perspectivas platônica e aristotélica acerca das condutas humanas.

Por exemplo, Montaigne apresenta a experiência como base da Medicina e, como Salutati, denuncia o caráter falacioso do seu procedimento de elaboração de regras: 
L'experience est proprement sur son fumier au subject de la medecine, où la raison luy quite toute la place. (...) Si faict la medecine profession d'avoir tousjours l'experience pour [pierre de] touche de son operation. (De l'Experience, p. 1079)

II n'est desir plus naturel que le desir de connoissance. Nous essayons tous les moyens qui nous y peuvent mener. Quand la raison nous faut, nous y employons l'experience (...) qui est un moyen plus foible et moins digne; (...) La raison a tant de formes, que nous ne sçavons à laquelle nous prendre; l'experience n'en a pas moins. La consequence que nous voulons tirer de la ressemblance des evenemens est mal seure, d'autant qu'ils sont tousjours dissemblables: il n'est aucune qualité si universelle en cette image des choses que la diversité et varieté. (...) La ressemblance ne faict pas tant un comme la difference faict autre. Nature s'est obligée à ne rien faire autre, qui ne fust dissemblable. [...] (ibid., p. 1065)

[...] tout exemple coche, et la relation qui se tire de l'experience est tousjours defaillante et imparfaicte [...] (ibid., p. 1070)

L'exemple est un miroüer vague, universel et à tout sens. (ibid., p. 1088).

Por outro lado, em sua crítica à pretensão científica da Jurisprudência, Montaigne aponta o caráter instável de seus fundamentos - de modo semelhante a Bracciolini e Vernia -, também atribuindo a origem das leis ao arbítrio humano: 
[...] il y a autant de liberté et d'estendue à l'interpretation des loix qu'à leur façon.” (Idem, p. 1065) “Qu'ont gaigné nos legislateurs à choisir cent mille especes et faicts particuliers, et y attacher cent mille loix? Ce nombre n'a aucune proportion avec l'infinie diversité des actions humaines. La multiplication de nos inventions n'arrivera pas à la variation des exemples." (Idem, p. 1066) "Or les loix se maintiennent en credit, non par ce qu'elles sont justes, mais par ce qu'elles sont loix. C'est le fondement mystique de leur authorité; elles n'en on poinct d'autre. [C] Qui bien leur sert. Elles sont souvent faictes par des sots, plus souvent par des gens qui, en haine d'equalité, ont faute d'equité, mais tousjours par des hommes, autheurs vains et irresolus. (ibid., p. 1072)

Além disso, Montaigne também reconhece o caráter instável, indeterminado, diverso e variável das ações humanas. Assim como Vernia, o autor dos Ensaios considera que o estatuto do objeto da Jurisprudência inviabiliza a pretensão 'científica' desta 'arte':

Qu'ont gaigné nos legislateurs à choisir cent mille especes et faicts particuliers, et y attacher cent mille loix? Ce nombre n'a aucune proportion avec l'infinie diversité des actions humaines. La multiplication de nos inventions n'arrivera pas à la variation des exemples. II y a peu de relation de nos actions, qui sont en perpetuelle mutation, avec les loix fixes et immobiles." (Idem, p. 1066) “Je laisse aux artistes, et ne sçay s'ils en viennent à bout en chose si meslée, si menue et fortuite, de renger en bandes cette infinie diversité de visages, et arrester nostre inconstance et la mettre par ordre. (ibid., p. 1076.) 
A constatação montaigneana da diversidade e da variação dos costumes e leis, que se assemelha à crítica feita por Bracciolini à pretensão científica da Jurisprudência, por outro lado, também é um caso da proximidade de argumentos:

C'est à la coustume de donner forme à nostre vie, telle qu'il lui plaist; elle peut tout en cela: c'est le breuvage de Circe, qui diversifie nostre nature comme bon lui semble. Combien de nations, et à trois pas de nous, estiment ridicule la crainte $d u$ serain, qui nous blesse si apparemment; et nos bateliers et nos paysans s'en moquent. Vous faites malade un Aleman de le coucher sur un matelas, comme un Italien sur la plume, et un François sans rideau et sans feu. L'estomac d'un Espagnol ne dure pas à nostre forme de manger, ny le nostre à boire à la Souysse. (...) Nous craignons les vins au bas; en Portugal cette fumée est en delices, et est le breuvage des princes. En somme, chaque nation a plusieurs coustumes et usances qui sont, non seulement incogneuës, mais farouches et miraculeuses à qualque autre nation. (ibid., p. 1080-1081)

Apesar da similaridade de argumentos e intenções ser a principal comprovação da referência montaigneana à Querela, deve-se também ressaltar como algo significativo o fato da discussão epistemológica ter se desenvolvido, em ambos os casos, em terreno aristotélico. Se Garin, por um lado, afirma que a disputa renascentista remonta a uma questão aristotélica desenvolvida no primeiro livro do De anima, Montaigne, por outro, desde a abertura de Da experiência, deixa claro que Aristóteles é uma das principais 
balizas de sua reflexão sobre as possibilidades de um 'saber' sobre as práticas humanas. $^{57}$

Que o autor dos Ensaios no mínimo conhecia a disputa, isto parece ser mais do que apenas plausível, uma vez considerado o evidente contato de Montaigne com a cultura italiana, apresentado não só pelo seu Journal de Voyage en Italie, mas perceptível inclusive em suas leituras, compiladas por Pierre Villey ${ }^{58}$. Interessa-nos ressaltar, a esse respeito, o fato de Montaigne ter tido contato direto com textos de Francesco Petrarca e Benedetto Varchi, participantes diretos da 'Querela'. Essas leituras montaigneanas, embora não reforcem substancialmente nossa hipótese - na medida em que não se referem às obras em que os autores tratam da 'Querela' ${ }^{, 59}$, mas a outras ${ }^{60}$-, ao menos

${ }^{57}$ Lembrando Aristóteles, Montaigne abre o ensaio que coroa sua obra da mesma forma que o filósofo estagirita inicia sua Metafísica - "Il n'est desir plus naturel que le desir de connoissance" (Les Essais, p. 1065) -, e menciona repetidamente Aristóteles ao longo do texto. A reflexão montaigneana, ressaltando a radical particularidade das ações e compleições corporais, problematiza tanto a idéia de uma 'ciência prática' das ações humanas, quanto a noção de medicina enquanto 'técnica', classificações inequivocamente aristotélicas. Se Pierre Villey estiver certo, contudo, o alvo montaigneano é antes o aristotelismo do século XVI do que o filósofo estagirita propriamente dito: "Souvent aussi Aristote est nommé moins pour ses opinions et doctrines qu'à cause de tendances qu'il represente au XVI siècle. Ces tendances, Montaigne en est l'adversaire, et il s'en prend à Aristote parfois pour les combattre..." (Villey, Les sources et l'evolution des Essais de Montaigne, T. 1, pps. 69-72).

${ }^{58}$ Villey compila as seguintes listas de italianos lidos por Montaigne: os moralistas Ficino, Castiglione, Bembo, Hebreo, Varchi, Guazzo, Tasso e Ringhieri; os poetas Aretino, Ariosto, Petrarca e Tasso; os historiadores Aretino, Giovio, Guicciardini, Villani e Giustiniano. Les sources et l'evolution des Essais de Montaigne, T.1, pps. 275, 279 e 282, respectivamente.

${ }^{59}$ Invectivarum contra medicum quemdam libri IV, de Petrarca, e Lezioni sulla pittura e scultura, de Varchi. 
nos obrigam a admitir alguma proximidade de Montaigne em relação à polêmica. $^{61}$

${ }^{60}$ II Petrarca, con nuove et brevi dichiarationi, insieme una tavola di tutti i vocaboli, detti, et proverbi difficili diligentemente dichiarati, de Petrarca; Lezzioni d'Amore e L' Ercolano, de Varchi. Cf. Villey, Les sources, T. 1, pps. 210 e 261.

${ }^{61}$ A esse respeito, cabe ainda lembrar a formação jurídica de Montaigne (Cf., sobretudo, André Tournon, Montaigne, la glose et l'essai). Segundo Villey, "Montaigne fora magistrado durante dezesseis anos..." (Les sources, T.1, nota 2 da p. 274). 


\section{ANEXO II}

\section{Platão e o paradigma da Arte $^{62}$}

O foco principal da reflexão conduzida por Montaigne acerca das artes médica e jurídica em Da experiência não é, como vimos, a investigação de elementos específicos das disciplinas, nem o exame crítico voltado para sua reconfiguração ou aprimoramento enquanto práticas. A intenção do autor, ao contrário, é uma desqualificação geral e de base: Montaigne ataca a medicina e a jurisprudência como práticas que buscam regular o campo das condutas humanas a partir de um conhecimento mais ou menos certo e seguro - isto é, como técnicas. Em suma, trata-se da desqualificação do estatuto epistêmico desta forma de racionalidade.

Para compreender a empresa montaigneana, adotamos como estratégia iniciar a pesquisa pela análise de algumas obras de Platão e Aristóteles, que não só foram sabidamente determinantes na formação do pensamento renascentista - servindo inclusive de pressupostos para a Querela referida no Anexo I -, mas que servem de balizas para a reflexão conduzida em $D a$ experiência, ensaio em que Montaigne, ainda que indiretamente, dialoga com

\footnotetext{
62 Julgamos pertinente anexar à dissertação este texto - escrito ainda no início de nossa pesquisa - não tanto para dar a conhecer um pouco do nosso percurso de estudos, mas, sobretudo, para aproximar nosso eventual leitor deste texto tão significativo - não só - da ética platônica. Parece-nos profícuo, ainda que o tenhamos feito de maneira muito limitada e incipiente, contrastar a recusa montaigneana (que pode ser depreendida do corpo da dissertação) de uma ética normativa, com a perspectiva platônica desenvolvida no Górgias, em que a técnica serve explicitamente de modelo para a moral.
} 
ambos.

Assim, iniciamos nossos estudos pelo exame da perspectiva platônica tal como ela se configura no Górgias, diálogo escolhido não somente pelas referências que Montaigne lhe faz de maneira dispersa e indireta ao longo do ensaio supracitado, mas, sobretudo, pelo campo de questões que compartilha com este. De fato, tanto Da experiência quanto o Górgias, em sua essência, tratam das perguntas éticas fundamentais (que conduta leva o homem à felicidade? em que consiste a virtude? qual é a tarefa essencial do homem na vida?) e buscam o saber capaz de respondê-las e de orientar as condutas humanas, afastando-as da arbitrariedade e da violência. Tal similaridade, no entanto, não a reencontramos nos caminhos que os autores percorrem, pois, como veremos com a exposição da ética desenvolvida no Górgias, Montaigne e o Platão deste diálogo divergem consideravelmente no que concebem como a boa conduta de vida.

Em linhas muito gerais, o Górgias conduz uma desqualificação da prática retórica, atividade por meio da qual, em fóruns deliberativos e judiciários, os oradores - diz a personagem Sócrates - pretendem designar o bem e o justo para a pólis e seus cidadãos, sem, contudo, conhecê-los efetivamente. Ao longo do diálogo, Sócrates mostra que os retores, procurando persuadir as assembléias, tribunais e conselhos da pólis por meio da crença (pistis) e não do ensino (Gorgias, 455a), não transmitem um saber, mas 
apenas manipulam opiniões ${ }^{63}$. Permanecendo no âmbito incerto e variado ${ }^{64}$ das doxai (terreno oposto ao do conhecimento, no qual se busca, por meio de um discurso impessoal ${ }^{65}$, a verdade e a não-contradição $0^{66}$ ), aqueles que praticam a retórica não conhecem a natureza (ibid., 465a) ou essência do justo e do injusto (ibid. 454b). Isto porque a retórica não é uma arte (tékhne), isto é, uma prática baseada no efetivo conhecimento de seu objeto - mas uma simples experiência (empeiria - ibid. 462c), ou seja, um procedimento rotineiro, em que se ignora as razões pelas quais se age da forma que se age (ibid. 501a), e se atua, então, a partir do puro hábito (ibid. 464c). E é justamente porque a retórica não é e não proporciona conhecimento que ela se reduz, segundo Sócrates, a uma parte da adulação (kolakeia - ibid., 464d): pois, sem conhecer a real natureza do bem - a virtude -, os homens que a praticam buscam equivocadamente o prazer como meio para a felicidade (e se limitam a reproduzi-lo na cidade).

Baseando-se somente em opiniões, os partidários da retórica - mostra Sócrates - estão sujeitos a tomar o falso pelo verdadeiro, o injusto pelo justo. É exatamente o que demonstra Polo, que sucede o próprio Górgias no debate com Sócrates e afirma que o poder de persuasão proporcionado pela retórica é um bem incomparável, à medida que torna quem o detém livre e capaz de dominar os outros, isto é, de agir justa ou injustamente em seu próprio proveito, de roubar, exilar ou levar à morte quem se queira, evitando sempre o castigo pelas injustiças cometidas:

\footnotetext{
${ }^{63}$ Cf. Górgias, 481e: "tu exprimes uma opinião..."

${ }^{64}$ Ibid., 482a: "diz ora uma coisa, ora outra..."

${ }^{65}$ Ibid.: "É ela (...) que diz sem cessar as coisas que tu me escuta dizer..."
} 
[...] o poder de persuadir pelo discurso [...] é realmente o bem supremo [...] dá a quem o possui a liberdade para si mesmo e a dominação sobre os outros na sua pátria [...] (ibid., 452d)

[...] os bons retores [...] não são todo poderosos nas cidades?

[...] eles não podem, como os tiranos, matar quem eles querem, espoliar e exilar quem quiserem? [...] (ibid., 466a-c) [...] justamente ou injustamente [...] de uma maneira ou de outra, eles não são dignos de inveja? [...] (ibid., 468e)

Mais à frente, é Cálicles, o mais despudorado dos interlocutores de Sócrates no diálogo, quem deve justificar esta assimilação da injustiça à justiça, com base em sua falsa opinião acerca da natureza (phýsis), que ele opõe à lei (nómos), que, ao contrário, é-lhe conforme. De acordo com o demagogo, a ação injusta é condenada pelos homens, mas é legítima segundo a natureza, para a qual o mais poderoso deve sobrepujar o menos poderoso:

[...] A natureza [...] nos prova que com justiça aquele que vale mais deve se elevar sobre o que vale menos, o capaz sobre o incapaz. Ela nos mostra [...] que a marca do justo é a dominação do poderoso sobre o fraco, e sua superioridade admitida. [...] segundo o direito natural, [...] todos os bens do mais fraco e do menos valente são propriedade do melhor e do mais poderoso [...] (ibid., 483a-484c)

A raiz oculta desta assimilação do injusto ao justo, no entanto - mostra Sócrates -, encontra-se em uma concepção equivocada do fim de todas as

\footnotetext{
${ }^{66}$ Ibid., 482b: “... a filosofia diz sempre a mesma coisa..."
} 
ações, pois os porta-vozes da retórica no diálogo somente defendem a ação injusta enquanto a tomam como meio para a obtenção do prazer ${ }^{67}$. Sócrates, portanto, chega ao núcleo problemático da moral sustentada por Polo e Cálicles quando identifica sua concepção de prazer como supremo bem e da intemperança - busca imoderada da satisfação - como meio para a felicidade e regra para a condução da vida:

[...] o belo e o justo, segundo a natureza, é o que eu estou explicando-te sem disfarce: a saber, que para bem viver é necessário manter em si mesmo as mais fortes paixões em vez de reprimi-las, que é necessário satisfazê-las, por mais fortes que elas sejam, por sua coragem e inteligência, dando-Ihes em grande quantidade tudo o que desejam. [...] a vida fácil, a intemperança, a licença, quando são favorecidas, constituem a virtude e a felicidade [...] (ibid., 491e-492d)

A partir daí, resta a Sócrates iniciar a desmontagem, ponto por ponto, das teses formuladas pelos porta-vozes da retórica. Antes de tudo, Sócrates considera que não é poderoso e livre aquele que só faz o que lhe agrada e de modo irrestrito, já que se deixa arrastar e escravizar pelo desejo (ibid., 466b468e). Ao contrário, somente aquele que faz o que quer, isto é, que age conforme a vontade - racional, necessariamente orientada para o bem - é verdadeiramente poderoso, livre, posto que é ele - e somente ele - que impõe a si mesmo suas regras (é autônomo). Sócrates ainda acrescenta que o homem levado a ações injustas por somente buscar o prazer é infeliz também porque a vergonha e a desonra acompanham mais quem comete injustiças do que

\footnotetext{
${ }^{67}$ Ibid., 467b: “...eles fazem o que Ihes agrada...”
} 
aquele que as sofre (ibid., 474c-475e), e que sumamente infeliz é o que evita o castigo por seus atos, perdendo a oportunidade de se desembaraçar dos maiores males - os da alma, superiores aos males do corpo (ibid., 476a-477e). Tal homem, enfim, é mais miserável que o doente que recusa a cura, pois recusa curar sua alma ${ }^{68}$ para poupar do flagelo seu corpo (ibid.).

A refutação socrática chega ao seu ápice quando se aplica à tese segundo a qual o verdadeiro bem é o prazer sem distinção. O ponto nevrálgico da ética sofística é atacado quando entra em cena Cálicles, o mais ousado dos três interlocutores de Sócrates, o único - ironiza o filósofo - que possui as qualidades essenciais "para se verificar se uma alma vive bem ou mal: benevolência, sabedoria e ousadia" ${ }^{69}$ Após refutar a oposição estabelecida por Cálicles entre nómos e phýsis, mostrando que as leis da maioria, condenando a injustiça, estão de acordo com a natureza, Sócrates revela a infelicidade do intemperante, recorrendo a mitos sobre o caráter insaciável das paixões e o sofrimento daquele que tem de "trabalhar noite e dia" (ibid., 494a), reiteradamente, em busca da satisfação - que deixa sempre escapar, por sua falta de memória. E ainda acrescenta que o intemperante, acreditando que o prazer sem distinção é o bem, leva uma vida vergonhosa e miserável, similar à do sarnento, que se compraz em aplacar indefinidamente sua 'coceira':

[...] Diga-me portanto primeiramente se é viver feliz ter sarna, experimentar a necessidade de se coçar, poder se coçar

\footnotetext{
${ }^{68}$ Ibid., 512a-b: "sua alma, mais preciosa que seu corpo...";

${ }^{69}$ Ibid., 487a. Parece haver, em Da experiência, uma referência a essa passagem do Górgias, indício de que Montaigne teria este diálogo em mente - entre tantas outras obras, sem dúvida - enquanto escrevia o ensaio: "Platon ordonne trois parties [qualités] à qui veut examiner l'ame d'un autre: science, bienveillance, hardiesse."(De l'experience, p. 1077).
} 
copiosamente e passar a vida a se coçar $[\ldots]^{70}$

[...] É somente na cabeça que é agradável ter o desejo de se coçar, ou devo levar mais longe minha interrogação? Pense, Cálicles, no que tu deverias responder se eu te colocasse todas as questões em seguida, e, para resumir tudo com uma palavra: a vida de um devasso não é horrorosa, vergonhosa e miserável? [...]

(ibid., 494c-e)

Mas, Sócrates somente termina de refutar a posição de Cálicles quando expõe as conseqüências absurdas da identidade entre prazer e bem, com as quais o demagogo não pode se comprometer. Antes de tudo - mostra o filósofo -, afirmar que o prazer é o supremo bem é um equívoco porque experimentamos simultaneamente o prazer e o sofrimento, mas não o bem e o mal (ibid., 495e497e). Além disso, tem como conseqüências as teses de que a ciência e a coragem não são bens (ou diferem do 'bem') (ibid., 495c-e), e de que 'o mau seria tão mau e tão bom quanto o bom, ou talvez um pouco melhor' (ibid., 497e-499c).

Mas, se o prazer sem distinção não é bom por princípio, não é menos verdade que haja prazeres bons, cuja identificação, no entanto, mostra

\footnotetext{
70 Ora, parecemos ver Montaigne zombar do moralismo do jovem Platão, referindo-se especificamente a esta passagem do Górgias, quando diz: II ne me souvient point de m'estre jamais veu galleux. Si est la gratterie des gratifications de Nature les plus douces et autant à main. [...] Je l'exerce plus aux oreilles que j'ay au dedans pruantes par saisons. (De l'experience, p. 1097)
} 
Sócrates, exige uma competência ou saber:

Sócrates - Mas cabe ao primeiro passante distinguir, dentre as coisas agradáveis, aquelas que são boas e aquelas que são más? Ou é o feito de um técnico particular para cada caso?

Cálicles - A competência é necessária. (ibid., 500a)

É na tékhne, então, que o filósofo encontra o modelo do saber capaz de nos orientar na distinção dos bens e dos males - ou seja, é na atividade voltada para a produção de um objeto cuja idéia ou forma (eidos) e cujo fim (télos) o artesão conhece, e que the fornecem as regras para suas ações, que podem, então, ser planejadas e justificadas:

[...] o homem virtuoso, aquele que diz tudo o que diz visando o supremo bem, ele fala ao acaso ou ele tem um alvo determinado em todos os seus discursos? Sucede com ele o mesmo que com os outros artesãos: cada um destes, com olhar fixado sobre sua tarefa própria, longe de recolher e de empregar ao acaso os materiais que emprega, visa realizar no que faz uma certa idéia. Considere, por exemplo, os pintores, os arquitetos, os construtores de navios e todos os outros artesãos, tome aquele que tu quiseres, tu verás com qual ordem rigorosa cada um dispõe os diversos elementos de sua obra, forçando-os a se ajustarem harmoniosamente uns aos outros, até que enfim todo o conjunto se mantenha e se ordene com beleza. [...] (ibid., 503d)

[...] a culinária me parecia ser um procedimento [empeiría] e não uma técnica [tékhne], diferentemente da medicina, e eu 
dava como razão que uma, a medicina, quando cura um doente, começa por estudar a natureza do doente, sabe porque ela age como tal, e pode justificar todos os seus passos; ao passo que a outra, cujo esforço tende todo ao prazer, caminha na direção de seu alvo sem nenhuma técnica, sem ter estudado a natureza do prazer e sua causa, entregue por assim dizer ao puro acaso, desprovida de todo cálculo, conservando somente por hábito e por rotina a lembrança do que se faz costumeiramente [...] (ibid., 501a)

Que a técnica seja uma competência, é algo que podemos aferir por meio dos sucessos do artesão, que, acumulando-se ao longo do tempo, são prova de sua experiência e preparo:

[...] Suponha agora, Cálicles, que, decididos a nos ocupar dos negócios públicos, nós nos exortássemos um ao outro a nos encaminhar na direção das construções [..]; nós não deveríamos nos examinar e nos interrogar primeiramente sobre nosso conhecimento ou nossa ignorância da técnica, a arquitetura? [...] não seria necessário verificar se nós anteriormente já elevamos alguma construção privada [...] e se esta construção é bela ou feia; depois, se nós descobrimos após exame [...] que nós construímos numerosos belos edifícios [...] então [...] nós poderíamos razoavelmente abordar as empresas públicas. Se ao contrário nós não tivéssemos [...] nenhuma construção anterior para lembrar, ou muitas construções sem valor, então seria absurdo pretender os grandes trabalhos públicos. [...] Sem ter iniciado por tentativas 
mais ou menos felizes [...], sem ter alcançado numerosos sucessos, nem estar convenientemente exercitado na técnica [...], este homem teria a audácia de procurar um serviço público? [...] (ibid., 514a-e)

[...] Não se vê os bons cocheiros primeiro firmes sobre seus assentos, e mais tarde, quando eles formaram sua parelha e ganharam experiência, deixando-se jogar para fora do assento. [...] (ibid., 516e)

Mas, em que sentido Sócrates faz da tékhne o modelo da ética? Ora, no sentido de que em ambos os casos a ação correta se dá única e exclusivamente por meio do conhecimento. É ele que fundamenta e garante a competência do artesão, assim como a virtude moral. Da mesma forma que o artesão produz sua obra com eficiência apenas porque sabe que deve atuar de tal ou tal maneira para obter determinado resultado, o virtuoso é capaz de agir bem tão somente porque conhece o bem. ${ }^{71} \mathrm{Em}$ suma, Platão entende que $a$

\footnotetext{
${ }^{71}$ Mais que isso, o homem virtuoso, conhecendo o bem - pensa Platão - necessariamente age bem. Para ele, de fato, é psicologicamente impossível agir viciosamente. Todos os homens querem ser felizes, e buscam a própria felicidade em todas as suas ações. Conhecendo o bem ou a virtude, e sabendo que ela é o único meio para a felicidade - pois é o único objeto de desejo cuja fruição não está à mercê das circunstâncias -, o homem age bem, age virtuosamente. Não existem desejos irracionais que interfiram em suas ações e o desviem da busca da própria felicidade, de modo que lhe é impossível conhecer o bem e agir mal. Cf. Terence Irwin, Plato's Ethics, pps. 68-70.
} 
verdadeira areté é o conhecimento do bem ${ }^{72}$.

O virtuoso é como o artesão porque conhece os meios capazes de conduzi-lo ao fim de suas ações. Ao conhecer o bem, ele é capaz de chegar à felicidade. No Górgias, a eudaimonia é alcançada quando a alma é justa e temperante, isto é, quando as paixões estão em equilíbrio e são moderadas pelo intelecto ${ }^{73}$. A ciência do bem que conduz à felicidade, nesse sentido, é o conhecimento da ordem (taxis) e da harmonia (kosmos) como aquilo que convém à alma, os valores supremos que the concernem ${ }^{74}$. Assim como no caso do artesão, portanto, o saber do homem virtuoso também é o conhecimento do que convém ao objeto que Ihe diz respeito - a alma ${ }^{75}$. Da mesma forma que a excelência da obra é o fim do artesão, a areté da alma condição da felicidade - é o objetivo do homem. Cabe a ambos não só agir sobre determinado objeto, mas agir corretamente, tornando-o excelente, isto é, fazendo emergir nele sua virtude própria. Para Platão, assim como toda técnica dá ordem e a harmonia à sua obra, da mesma forma o virtuoso faz com sua alma. $^{76}$

Nesse sentido, o homem virtuoso é aquele que ordena seus prazeres e

\footnotetext{
${ }^{72}$ Coragem, temperança e todas as virtudes são belas e boas apenas na medida em que se baseiam no saber. Assim, por exemplo, a verdadeira coragem não é "a tola firmeza de ânimo", mas "a firmeza sábia", qualidade do homem que "sabe que deve enfrentar um severo perigo" porque conhece "os benefícios e prejuízos da ação", e "sabe que a comparação dos [mesmos] justifica o enfrentamento do perigo".

${ }^{73}$ Górgias, 507c.

${ }^{74}$ Idem, 504d

${ }^{75}$ Em Górgias, 503d-504e, o paralelo é explícito e direto. O virtuoso é técnico de sua própria alma.
} 
paixões, disciplinando-os e submetendo-os a um cálculo racional que indica a conduta a ser tomada a partir de uma mensuração de prazeres e desprazeres, assim como de uma avaliação dos mesmos em função de suas possíveis conseqüências. Prazeres ou dores, para Platão, não devem ser simplesmente recusados ou reivindicados - como fazem os cínicos e cirenaicos. Ao contrário, eles devem ser objeto de uma avaliação técnica que verifique sua apreciabilidade tanto do ponto de vista de sua inserção numa totalidade de prazeres ou dores conectados entre si, quanto da perspectiva de seus desdobramentos futuros, que devem ser objeto de uma previsão. Qualidades tipicamente pertencentes ao técnico, mensuração, avaliação e previsão - ou, em suma, cálculo racional - tornam-se os princípios diretivos das ações do homem virtuoso.

A virtude da temperança, enfim, é recomendada pela própria natureza: deve ser buscada como supremo bem porque é conforme à phýsis, visto que o próprio cosmos - o natural e o sobrenatural, 'deuses e homens, céu e terra' - é regido pela ordem e harmonia, pela igualdade geométrica ${ }^{77}$.

Fundamentando, assim, sua concepção de virtude na natureza, Platão refuta definitivamente a posição de um Cálicles, para quem o elogio da temperança e a defesa justiça e da igualdade não passam de "fantasmagorias que repousam sobre convenções humanas contrárias à phýsis” (ibid., 492c).

\footnotetext{
${ }^{76}$ Idem, ibidem.

${ }^{77}$ Cf. Górgias, 508a.
} 


\section{REFERÊNCIAS BIBLIOGRÁFICAS}

ABRAND, DR. H. - Montaigne, les médecins et la médecine. Commentaires par G. Guichard. (Bulletin de la Société des amis de Montaigne, 2e. sér., no. 12, pp. 10-26 [les commentaires occupent les pp. 17 à 26]; Paris, 1942)

ADORNO, T. W. - "O ensaio como forma", in Notas de Literatura I, Duas Cidades/Editora 34 (Coleção Espírito Crítico), São Paulo, 2003

ANATOLE, CHR. - De Montaigne et de la justice. (Littératures [Annales publiées par la Faculté des lettres de Toulouse] Nouvelle Série, Toulouse, XI, 1975, vol. XXII, pp. 13-29)

ARISTÓTELES - De l'âme, traduction et notes par J. Tricot, Paris, J. Vrin, 1959

- Etica Nicomachea, traduzione di Carlo Natali, Roma-Bari, Editori Laterza, 2005.

- Éthique à Nicomaque, traduit par J. Tricot, Paris, Vrin, 1997.

- Les Premiers Analytiques, traduit par J. Tricot, Paris, Vrin, 1946.

- Les Seconds Analytiques, traduit par J. Tricot, Paris, Vrin, 1950.

- Métaphysique, traduit par J. Tricot, Paris, Vrin, 1964.

- Nicomachean Ethics, by Christopher Rowe and Sarah Broadie, New York, Oxford University Press, 2002.

- Rhétorique, Livre I; Paris, Les Belles Lettres (Collection des Universités de France), 1932.

- Topiques, texte établi et traduit par J. Brunschwig, Paris, Les Belles Lettres, (Collection des Universités de France), 1967.

AUBENQUE, PIERRE - A Prudência em Aristóteles, São Paulo, Discurso Editorial, 2003.

AUERBACH, E. - “L'Humaine Condition”, in Mimesis: a realidade na literatura, 
Edusp/Perspectiva, São Paulo, 1971, pps. 245-270

AVERRÓES - Epitome de anima, Ed. Salvator Gómez Nogales, Madrid, Consejo Superior de Investigaciones Científicas, Instituto "Miguel Asín"-Instituto Hispano Arabe de Cultura, 1985

BALDI, GIOVANNI - Disputatio an Medicina sit legibus politicis praeferenda; in La Disputa delle arti nel Quattrocento (a cura di E. Garin), Firenze, Vallecchi, 1947 BARAZ, MICHAEL - "Sur la structure d' essai de Montaigne (III, XIII - De l'experience)", in Bibliothèque d'Humanisme et Renaissance, vol. XXIII Genebra, 1961 BARTHES, ROLAND - A retórica antiga, in Pesquisas de Retórica (Cohen, Jean et alii), Petrópolis, Vozes, 1975.

BATISSE, DR. F. - Montaigne et la médecine. - Paris, Les Belles-Lettres, 1962; in-80, 292 pp., bibliogr.

BERTI, ENRICO - As Razões de Aristóteles, São Paulo, Edições Loyola, 1998.

BIGNOTTO, N. - "Montaigne renascentista”, in Kriterion - Revista de Filosofia, no. 86, Belo Horizonte, UFMG/FAFICH, 1992.

BIRCHAL, T. - Montaigne e seus duplos: elementos para uma história da subjetividade. Tese de Doutorado, FFLCH-USP, mimeo, 2000.

BOUCHARD, P. - Recherche sur la structure philosophique des Essais 11, 12, 13 du livre III. (Bulletin de la Société des amis de Montaigne, 5a. Sér., no. 14-15, pp. 81-88; Paris, 1975)

BOURGEY, L. - A medicina grega desde as origens até o fim da época clássica, in A Ciência Antiga e Medieval, Tomo I, Vol. II; São Paulo, Difusão Européia do Livro, 1959.

BRACCIOLINI, POGGIO - Convivalis disceptatio, utra artium, Medicinae an iuris civilis, praestet; in La Disputa delle arti nel Quattrocento (a cura di E. Garin), Firenze, Vallecchi, 1947

- Oratio in laudem legum; in La Disputa delle arti nel

Quattrocento (a cura di E. Garin), Firenze, Vallecchi, 1947 
BRAHAMI, F. - Le Scepticisme de Montaigne, PUF, Paris, 1997

BRODY, JULES - “Trois études sur De l'Expérience”, in Nouvelles Lectures de Montaigne, col. Études Montaignistes, vol. XV - Honoré Champion Éditeur, Paris, 1994 - "Montaigne et la notion de litterature: deux études sur De l'Expérience", in Lectures de Montaigne, French Forum Publishers, Lexington, 1982 BRUN, JEAN - O Epicurismo, trad. Rui Pacheco, Lisboa, Edições 70, 1987 - O Estoicismo, trad. João Amado, Lisboa, Edições 70, 1986

BRUNI, LEONARDO - Epistola a Niccolò Strozzi; in La Disputa delle arti nel Quattrocento (a cura di E. Garin), Firenze, Vallecchi, 1947

BURCKHARDT, JACOB - A Cultura do Renascimento na Itália, São Paulo, Companhia das Letras, 2003

CAMBIANO, GIUSEPPE - Platone e le tecniche, Torino, Einaudi, 1971.

CARDOSO, SÉRGIO - "O homem, um homem: do humanismo renascentista a Michel de Montaigne”, in Perturbador Mundo Novo, Escuta, São Paulo, 1992

- “Uma fé, um rei, uma lei - A crise da razão política na França das Guerras de Religião", in A Crise da Razão, Companhia das Letras/Funarte, São Paulo, 1996.

- "Villey e Starobinski: duas interpretações exemplares sobre a gênese dos Ensaios", in Kriterion - Revista de Filosofia, vol. 23, no. 86, agosto/setembro de 1992.

- "Antigos, Modernos e Novos Mundos da Reflexão Política", in Novaes, A. (org.), A invenção do Estado Nação, Companhia das Letras, São Paulo, no prelo.

- "Paixão da igualdade, paixão da liberdade: a amizade em Montaigne", in Novaes, A. (org.), Os Sentidos da Paixão, Companhia das Letras/Funarte, São Paulo, 2006 (13ª edição)

CASTORIADIS, C. - "Técnica”, in Encruzilhadas do Labirinto, Vol. 1 (Trad. Carmen Guedes e Rosa Boaventura), Rio de Janeiro, Paz e Terra, 1987 
CHARPENTIER, F. - “Ces poinctes eslevées de la Philosophie...”: l'éthique des derniers essais", in Cahiers Textuel, 34-44, no. 2, 1986

CHAUÍ, MARILENA - Introdução à História da Filosofia - vol. 1, Companhia das Letras, São Paulo, 2003

COLOMBERO CARLO - Uomo e natura nella filosofia Del Rinascimento, Loescher, 1976

COMPAGNON, ANTOINE - “"De l'Expérience”: un exercice de patience”, in Montaigne et Les Essais - 1588-1988, Actes du congrès de Paris (janvier 1988) réunis par Claude Blum; Librairie Honoré Champion, Paris, 1990

COMPAIN, J. M. - A propos de la composition de l'essai De l'experience (13, III). (Bulletin de la Société des amis de Montaigne, 5a. Sér., no. 7-8, pp. 39-44; Paris, 1973)

CONS, LOUIS - Montaigne et l'idée de justice. (Mélanges de littérature, d'histoire et de philologie offerts à Paul Laumonier par ses élèves et ses amis, Paris, Droz, 1935, in-80., pp. 347-54).

D’AREZZO, GIOVANNI - De Medicinae et legum praestantia; in La Disputa delle arti nel Quattrocento (a cura di E. Garin), Firenze, Vallecchi, 1947

DA SIENA, BERNARDO - Dal Commento ai Trionfi del Petrarca; in La Disputa delle arti nel Quattrocento (a cura di E. Garin), Firenze, Vallecchi, 1947

DE'FERRARIIS, ANTONIO (DETTO IL GALATEO) - De dignitate disciplinarum ad Pancratium; in La Disputa delle arti nel Quattrocento (a cura di E. Garin), Firenze, Vallecchi, 1947

DESJARDINS, J. - Sur un passage des Essais (III, 13). (Bulletin de la Société des amis de Montaigne, 3a. Sér., no. 4, pp. 05-10; Paris, 1957)

DHOMMEAUX-SAULEAU, J.-P. - Montaigne et sa critique de la justice française. (Bulletin de la Société des amis de Montaigne, Paris, 4e sér., no. 17, 1969, pp. 14-24)

DUJARRIC DE LA RIVIÈRE, DR. R. - Montaigne et la médecine. (Revue 
générale des sciences pures et appliquées, LXV, nos. 3-4, pp. 93-108; Paris, 1958 Réimpr. Dans le Bulletin de la Société des amis de Montaigne, 3e. sér., no. 27, pp. 317; Paris, 1963)

EVA, L. A. A. - “A vaidade de Montaigne”, in Discurso, no. 23, pps. 25-52, Discurso Editorial, São Paulo, 1994.

- Ceticismo e Paradoxo nos Ensaios de Montaigne, Tese de Doutoramento, FFLCH-USP, mimeo, 1999

- "Montaigne e o ceticismo na Apologia de Raimond Sebond: a natureza dialética da crítica à vaidade", in O que nos faz pensar, 8, nov. 1994, pps. 106-117

- Montaigne e o ceticismo na Apologia de Raimond Sebond (mimeo), Dissertação de Mestrado defendida junto à FFLCH-USP, sob a orientação do Prof. Dr. Oswaldo Porchat, em março de 1994, 221p.

FEYTAUD, J. DE - Un doux et mol chevet (Bulletin de la Société des amis de Montaigne, 2a. Sér., no. 18, pp. 28-35; Paris, 1956)

FRAME, DONALD M. - To 'Rise above humanity' and to 'Escape from the man': two moments in Montaigne's thought. (The Romanic review, LXII, no. 1, pp. 2835; New York, 1971)

FRIEDRICH, HUGO - Montaigne, Traduit de l'allemand par Robert Rovini; Collection Tel, Gallimard, Mesnil-sur-l'Estrée, 2002

GARIN, E. - Introduzione al De nobilitate legum et Medicinae, de Coluccio Salutati, Firenze, Vallecchi, 1974

- Umanesimo e vita civile, in Atti della Colombaria, XV, Firenze, 1947

GENTILE, G. - Studi sul Rinascimento, Firenze, Sansoni, 3a. ed. 1968

GUITARD, E. - H. - Montaigne et l'art de guérir. (Revue d'histoire de la pharmacie, XLIII, no. 147, pp. 189-97; Paris, 1955 - e XLIV, no. 148, pp. 249-65; Paris, 1956). - En publ. séparée: - Paris, Société d'histoire de et pharmacie, 1956; in-80, 32 pp., pl., portr. 
IANNIZZOTTO, M. - Saggio sulla filosofia di Coluccio Salutati, Padova, Milani, 1959

IRWIN, TERENCE - Plato's Ethics, New York, Oxford University Press, 1995.

ISHIGAMI-IAGOLNITZER, MITCHIKO. - Le Quod nihil scitur de Sanchez et l'essai De l'experience de Montaigne. (Bulletin de la Société des amis de Montaigne, 5e. sér., no. 9, pp. 11-19; Paris, 1974)

KRISTELLER, P. O. - Humanism and Scholasticism in the Renaissance, ‘Byzantion’, XVII, 1944-1945

- Otto pensatori del Rinascimento italiano (trad. it. di R. Federici), Milano-Napoli, Ricciardi, 1970

LAIGNEL-LAVASTINE, DR. M. - L'esprit clinique de Montaigne contre la médecine de son temps. (Bulletin de la Société des amis de Montaigne, 2e. sér., no. 11, pp. 14-15; Paris, 1941)

LEOPOLDO E SILVA, F. - "A referência a Montaigne na concepção pascaliana de história", in Kriterion - Revista de Filosofia, no. 86, Belo Horizonte, UFMG/FAFICH, 1992.

LONG, ANTHONY - La Filosofia Helenística - Estoicos, Epicúreos, Escépticos, trad. P. Jordan de Urries, Madrid, Alianza Editorial, 1977.

LUKÁCS, G. - "Sobre la esencia y forma del ensayo", in El Alma y las Formas, Grijalbo, Buenos Aires, 1970

MEIJER, MARIANNE S. - "Guesswork or Facts: Connections between Montaigne's Last Three Chapters (III: 11, 12 and 13)", in Montaigne: Essays in Reading, Yale French Studies no. 64; Yale University Press, Connecticut, 1983 MELANCHTHON, PHILIP - "On the honor of Medicine" e " On the honor of Law", in Orations on philosophy and education, Cambridge University Press, New York, 1999

MENGONI, LUIGI - I pensieri di Montaigne sul diritto. (Rivista internazionale di filosofia del diritto, Genova, Roma, Milano, 1973, pp. 285-99) 
MERLEAU-PONTY, MAURICE - "Leitura de Montaigne”, in Sinais, tradução de M. E. G. Gomes Pereira, Martins Fontes, São Paulo, 1991

MICHEL, P. - Pour mieux lire le livre III des Essais. (Bulletin de la Société des amis de Montaigne, 4a. Sér., no. 12, pp. 9-24; Paris, 1967)

MONTAIGNE, MICHEL DE - Les Essais, Édition de Pierre Villey, reéditée par V. L. Saulnier; Col. Quadrige, PUF, Paris, 1999.

- Essais, Imprimerie Nationale Éditions, Paris, 1998.

- Os Ensaios, Martins Fontes, São Paulo, 2001.

- Ensaios, trad. de Sérgio Milliet, Os

Pensadores, Abril Cultural, São Paulo, 1980.

NAKAM, GÉRALDE - “Langage de l'esprit, Langage du corps dans les derniers "essais" des Essais", in Montaigne, les derniers essais - Actes de la journée d'étude Montaigne; Textes réunis par Françoise Charpentier; UER - Cahiers Textuel, 34-44, no. 2, Université Paris VII, Paris, 1986

NARDI, B. - Saggi sull'aristotelismo padovano dal secolo XIV al XVI, Firenze, Sansoni, 1958

PALMIERI, M. - Della vita civile (a cura di F. Battaglia), Bologna, Zanichelli, 1944

PATIN, GUY - Montaigne et son opinion sur les médecins - P. 25 [lettre du 12 septembre 1645] des: - Lettres choisies de feu Monsieur Guy Patin, docteur en médecine et professeur au Collège de France... - Francfort, J.-L. Du-Four, 1683; in-12, 522 pp.

PERINE, M. - Retórica é/e Filosofia. Leituras do Fedro, in Revista Hypnos, ano 8, no. 11, São Paulo, PUC, 2ํㅗ sem. 2003.

PETRARCA, FRANCESCO - Invectivarum contra medicum quemdam libri IV (a cura di M. Schiavone), Milano, Marzorati, 1972

PIROTTI, U. - Benedetto Varchi e la cultura del suo tempo, Firenze, Olschki, 
1971

PLATÃO - Phèdre, Paris, Les Belles Lettres (Col. Classiques en Poche Bilingue français/grec), 2002.

- Gorgias, Les Belles Lettres (Classiques en Poche - Bilingüe),

Paris, 2002

PORCHAT PEREIRA, O. - Ciência e Dialética em Aristóteles, São Paulo, Editora Unesp, 2001.

RENDALL, STEVEN - "De l'experience (3. 13)", in Distinguo: Reading Montaigne Differently; Clarendon Press, Oxford, 1992

ROSS, W. D. - Aristotle, New York, Dover Publications, 1955.

SACCHI, B. - De optimo cive (a cura di F. Battaglia), Bologna, Zanichelli, 1944

SALUTATI, C. - De nobilitate legum et Medicinae (a cura di E. Garin), Firenze, Vallecchi, 1974

SANTORO, M. - Fortuna, ragione e prudenza nella civilità letteraria del Cinquecento, Napoli, Signori, 1967

SMITH P. J. - "Continuar e conservar: Montaigne e o poder", in História: questões e debates (Depto. de História - UFPR), ano XIII, no. 25, pps. 58-81, jul.-dez. 1996

STAROBINSKI, JEAN - Montaigne em Movimento, Tradução de Maria Lúcia Machado; Companhia das Letras, São Paulo, 1993

THORNDIKE, LYNN - Science and Thought in the Fifteenth Century, New York, 1929

- Medicine versus Law in late medieval and Medicean Florence, in Romanic Review, XVII

TRONQUART, G. - Pour une interprétation cosmique du 'Mol Chevet'. (Bulletin de la Société des amis de Montaigne, 3a. Sér., no. 1, pp. 28-32; Paris, 1957)

ULLMANN, B. L. - The Humanism of Coluccio Salutati, Padova, Antenore, 1963 
VALLERY-RADOT, DR. PIERRE - Le scepticisme médical de Montaigne. (Le Fureteur médical, XVIII, no. 5, pp. 131-39; Paris, 1959)

VARCHI, B. - Lezioni sulla pittura e scultura, in Opere (a cura di A. Racheli), Trieste, Lloyd Austriaco, 1860, vol. II

VARESE, C. - Storia e politica nella prosa del Quattrocento, Torino, Einaudi, 1961

VERNANT, J.-P. - Mito e Pensamento entre os Gregos, São Paulo, Difusão Européia do Livro/EDUSP, 1973.

VERNANT, J.-P. \& DETIENNE, M. - Les Ruses de l'intelligence. La mètis des grecs. Paris, Flammarion, 1974.

VERNIA, NICCOLETTO - Quaestio an Medicina nobilior atque praestantior sit iure civili; in La Disputa delle arti nel Quattrocento (a cura di E. Garin), Firenze, Vallecchi, 1947

VILLEY, P. - Les sources et l'évolution des Essais de Montaigne, Osnabrück: Otto Zeller, 1976 (reimpressão da 2a. edição de 1933, Paris, Librairie Hachette) - Les Essais de Montaigne, col. "Les Grands évènements littéraires”, Nizet, Paris, 1992

- Montaigne et Francis Bacon, Slatkine Reprints, Genève, 1973 WALSER, E. - Poggius Florentinus. Leben und Werke, Leipzig, Teubner, 1914 XENOFONTE - Econômico (trad. Anna Lia Amaral de Almeida Prado), São Paulo, Martins Fontes, 1999. 